\title{
Modernising English Land Law
}

\author{
Graham McBain ${ }^{1,2}$ \\ ${ }^{1}$ Peterhouse, Cambridge, UK \\ ${ }^{2}$ Harvard Law School, USA \\ Correspondence: Graham McBain, 21 Millmead Terrace, Guildford, Surrey GU2 4AT, UK. E-mail: \\ gsmcbain@aol.com
}

Received: January 22, 2019

Accepted: February 28, 2019

Online Published: March 5, 2019

doi:10.5539/ilr.v8n1p30

URL: https://doi.org/10.5539/ilr.v8n1p30

\section{INTRODUCTION}

At present, the legal situation in respect of land in England and Wales is confusing. Title to most land in England and Wales is now registered. However, title to some $15 \%$ (or less) is still governed by older legal principles, including the need for title deeds. Further, there are many antiquated pieces of legislation relating to land still existing - various pieces of which are obsolete and others which should be re-stated in modern language. For a list of existing land legislation, see Appendices A-B.

Antiquated (and obsolete) land legislation complicates the legal position as well as prevents the consolidation of English land law. Such has major financial implications since a clearer, consolidated, land law would help speed up land sales - including house purchases - and reduce costs for businesses and individuals. Also, old laws can (often) be a "trap for the unwary." The purpose of this article is to consider various ancient pieces of land legislation and to argue that they should be repealed. In particular, this article argues for the repeal of the following:

- Inclosure Acts. Until the $1^{\text {st }}$ World War (1914-8), some arable land was still farmed on an 'open' field (that is, a 'common' field) system - one little different to that in Anglo-Saxon times. ${ }^{2}$ However, the last inclosure of such pursuant to legislation (whether general, local or private) was in 1914 (at the latest) and there are believed to be no open fields farmed today, besides one in Laxton which has been especially retained. ${ }^{3}$ Despite this, there are still a large number of Inclosure Acts still extant (those of $1773,1833,1845,1846,1847,1848,1849,1852,1854,1857,1859$ and 1868) as well as a (very) large number of local and private Acts that govern inclosure. ${ }^{4}$ All of these should be repealed as obsolete (spent) both because of the absence of any open field system still existing (save one) and the fact that the Commons Act 1876 (extant) and later legislation was designed to supercede these Inclosure Acts, the latter having a different policy - one of regulation as opposed to inclosure (the latter extinguishing rights of common);

- Subinfeudation - Ouia Emptores 1290. This legislation prohibits the subinfeudation of land in fee simple (but not in fee tail or of a life interest). Its purpose was to prevent a loss of tenurial services (and the financial benefit of the same) to the Crown as well as to mesne lords. However, the language is

\footnotetext{
${ }^{1}$ Lord Upjohn, Chairman of the Joint Committee of the House of Lords and the House of Commons on the Statute Law (Repeals) Bill 1969, noted that 'anybody who has seen even the first volume of the Statutes Revised will realise that there is still a good deal of old statutes sometimes rotting sometimes mysterious, which are still in the Statute Book'. He continued 'This...might be said to cause no harm, but the practical matter is that the failure to repeal them...can be a real nuisance to busy practitioners, and is not always helpful to clients. It may be that in the isolated case his rights would be determined by reference to an old Statute but often if his advisers are in doubt it will not help him that it is on the Statute Book. It has proved also that the existence of these statutes has been a bit of a stumbling block to consolidation.' See also R (Rushbridger) $v$ A-G [2004] 1 AC 357 at pp 377-8 per Lord Walker 'it is most undesirable that obsolete statutes should remain unrepealed. Quaint language and interesting historical associations are no justification for preserving obsolete statutes in a mummified state.'

${ }^{2}$ In a common field system a field is farmed by more than one farmer, being divided into strips. This strip farming may have originating in Anglo-Saxon times, deriving from German precedent. However, it is also likely that it is existed in some form in Roman Britain. See also DR Denman, Origins of Ownership (George Allen, $2^{\text {nd }}$ ed, 1959), pp 58-9 and n 12. Obviously, what was suitable to the ancient plough is not so to the modern tractor and laser guided ploughing.

${ }^{3}$ For the (three) open fields at Laxton, see 5(a).

${ }^{4}$ At least, 4,000 private Acts for the inclosure of land were passed pre-1845, see $\mathrm{n} 72$. Further, many local Acts, providing for the enclosure of land in particular parts of England in the past, are extant.
} 
archaic. This Statute should be repealed and modern legislation should provide (in simple language) that the subinfeudation of land is prohibited (excepting the Crown) $;^{5}$

- Entailed Interest - Statute de Donis Conditionalibus 1285. In times past land was (sometimes) granted by a settlor in a particular fashion so as to seek to preserve it in the same family for generations. Often, the grant was of a life interest with the remainder to another and his lineal heirs ('heirs of his body'), such wording excluding the latter's ancestors and collateral heirs. The Statute de Donis Conditionalibus 1285 (i.e. Statute of Westminster 1285, chapter 1, 'De Donis'), which is still extant, confirmed the validity of such grants. However, such entailed interests (often), also, resulted in the unproductive use of estates and they became less common in later Victorian times. Further, statutory means were adopted (or permitted by the courts) to break the entail. The Trusts of Land and Appointment of Trustees Act 1996 (the '1996 Act') prevented the creation of entailed interests post-1996. However, it left untouched those existing prior to the same. It is asserted that the Statute de Donis (and other legislation governing entailed interests) should be repealed. And, that all entailed estates still existing should now be governed by the 1996 Act. This would modernise the law in this area and remove much antiquated and complex legislation;

- Settled Land - Settled Land Act 1925. Entailed estates comprise 'settled land' under the Law of Property 1925. So do other estates involving a succession of interests as well as some that do not. Such estates cannot be created post-1996 due to the 1996 Act. However, those still existing prior to 1996 are not governed by the 1996 Act; they remain 'settled land'. It is asserted that the Settled Land Act 1925 (and other legislation governing settled land) should be repealed. And, that all settled land still existing should now be governed by the 1996 Act. This would modernise the law in this area and remove much antiquated and complex legislation;

- Wife of Unsound Mind - Statute concerning Tenants by the Curtesy of England (pre-1285). This legislation (although it may only be an opinion) of uncertain date (but pre-1285) was repealed by the Administration of Estates Act 1925 ('AEA 1925') in respect of deaths occurring post-1925. However, the AEA 1925, s 51(2), indicated that the (new) rules of intestacy in the Act did not apply to any beneficial interest of a person of unsound mind or of low mental aptitude (s 51(2) refers to them as lunatics and defectives). Their estate was to still devolve in accordance with the law pre-1926. Section 51(2), inter alia, affects matters covered by the Statute concerning Tenants by the Curtesy. However, the Statute (estate by curtesy) - when construed with s 51(2) - can now only apply to a husband taking a life interest in his wife's lands and hereditaments which she acquired when of unsound mind pre-1926 and where she was living and of full age (i.e. 21 and over) post-1926. Thus, it means - for the Statute and s 51(2) to apply - this now only covers: (a) the acquisition of an estate by a wife of unsound mind some 113 years (or more) ago; (b) a husband still alive today; (c) she had a son (or daughter) by him; (d) she died intestate and still of unsound mind; and (d) the estate is not in Northern Ireland (the Statute does not apply there). It is asserted no such person would now fall into this category and that - even if they did - the law of intestacy post-1926 is more appropriate to apply. Thus, the exception in the AEA 1925 , s 51(2) relating to the Statute should be repealed. So should this section generally, since it applies to the intestate estates of persons categorised as 'lunatics' and 'defectives' (expressions no longer used) pre-1925 and, in any case, there is likely to be no one in this category living today (they would have to be extremely old) ${ }^{6}$

- Waste \& Distress - Statute of Marlborough 1267. Chapter (section) 23 of this Act imposes a fine (amerciament) for permissive waste. This chapter should be repealed since waste is now (better) covered by the modern law of tort, equity and contract. Other chapters (which relate to distress) should also be repealed. Thus, this Act should be wholly repealed;

- Other Land Legislation. Various pieces of Victorian legislation concerning land should now be repealed, as unnecessary and no longer utilised. In particular, the Literary and Scientific Institutions Act

\footnotetext{
${ }^{5}$ See 8 .

${ }^{6}$ This can be best achieved by repealing s 51(2). This will affect other estates (other than by custesy) of intestate persons of unsound mind ('lunatics') as well as those of low mental aptitude ('idiots', 'defectives') acquired pre-1926. However, it is appropriate that the modern law of intestacy should, also, now govern them. It may be noted that the purpose of curtesy was to entitle the husband of a female tenant in socage to a life interest in those lands of inheritance of which she was actually seised, from the time that issue capable of inheriting was born by her to him. See E Jenks, Modern Land Law (1899), p 21.
} 
1854 and the School Sites Acts 1841-52, which institutes and schools were often built on inclosed (manorial waste) land.

If the above legislation is repealed, it is asserted the following should be undertaken:

- Consolidation. Extant legislation relating to commons, allotments, parks and gardens, town and village greens and national parks should be consolidated in an Open Spaces Act; ${ }^{7}$

- Military Land and Crown Acts. Victorian legislation on military land should be modernised and consolidated in one Act, together with other, older, legislation on the Armed Forces. ${ }^{8}$ And, legislation on Crown Lands (together with that on the Crown Estate) should be consolidated in a Crown Act, see Appendix B (f);

- $\quad$ Remaining Land Legislation. This should be consolidated into three Acts, viz: (a) a Land Act; (b) a Landlord and Tenant Act; (c) an Open Spaces Act. See Appendices A-B;

- $\quad$ Unregistered Land. Provision should be made for the registration of remaining unregistered land by 2025 , with a penalty if not so undertaken.

The above simple measures would (hugely) help ordinary individuals and businesses as well as the British economy generally.

\section{INCLOSURE OF COMMON LAND}

The first area to consider in respect of the repeal of obsolete land legislation is that relating to the inclosure of common land. There are various, older, legal texts dealing with inclosure, both pre-1800 ${ }^{9}$ Victorian; ${ }^{10}$ and more modern. ${ }^{11}$ A useful general text is Slater, The English Peasantry and the Enclosure of Common Fields (1907). ${ }^{12}$ There are also texts looking, in particular, at inclosures in the $16^{\text {th }}$ century. ${ }^{13}$

\footnotetext{
${ }^{7}$ Commons, parks, allotments and greens are related since the latter two (generally) derived from the former. 'Open spaces' was a Victorian expression to refer to parks and other areas of land (mainly, manorial waste) which the general public used for recreation.

${ }^{8}$ Legislation comprises the Military Lands Acts 1892, 1897, 1900 \& 1903 and the Defence of the Realm (Acquisition of Lands) Acts 1916 and 1920. Also, the Land Powers (Defence) Act 1958.

${ }^{9}$ See, in particular: (a) T Gurdon, History of the High Court of Parliament... and the History of Court Baron and Court Leet, with the rights of Lords of Manors in Common Pastures (1731); (b) Anon, The Law of Commons and Commoners ( $2^{\text {nd }}$ ed, 1720); (c) Anon, Reasons against the Inclosing of Commons without the consent of the Tenants showing the tenants right in the lords wastes by the common law and by several Acts of Parliament from 20 Hen III [i.e. 1235] to 3 Edw VI [i.e. 1548 ] (1661). See also E Coke, Institutes of the Laws of England (W Clarke \& Sons, London, last ed, 1824) and W Blackstone, Commentaries on the Laws of England (Oxford, Clarendon Press, $1{ }^{\text {st }}$ ed, 1765-9, Univ. of Chicago Press rep 1979).

${ }^{10}$ See, in particular: (a) JB Bird, The Laws respecting Commons and Commoners ( $2^{\text {nd }}$ ed, 1806); (b) GF Chambers, Law of Commons and Open Spaces (1877); (c) GW Cooke, Acts for Facilitating the Enclosure of Commons in England and Wales $\left(1^{\text {st }}\right.$ ed, 1846; $4^{\text {th }}$ ed, 1864); (d) T Coventry, Observations on Title to Land through Inclosure Acts (1827); (e) CI Elton, Treatise on Commons and Waste Lands (1868); (f) J Finlaison, Public Rights over Wastes and Common Lands (1867); (g) JE Hall, Law relating to Profits a Prendre and Rights of Common (1871); (h) R Hunter, Preservation of Open Spaces, Footpaths and other Rights of Way ( $1^{\text {st }}$ ed, 1896; $2^{\text {nd }}$ ed 1902); (i) HW Peek, Six Essays on Commons Preservation, containing a legal and historical examination of manorial rights and customs (1867); (j) JT Pratt, Law for Facilitating the Enclosure of Open and Arable Fields in England and Wales (1837); (k) TE Scrutton, Commons and Common Fields or History and Policy of the laws relating to Commons and Enclosures in England (1887); (1) G Shaw-Lefevre (Lord Eversley), English Commons and Forests (1894); (m) W Williams, Rights of Common and other Prescriptive Rights (1880); (n) W Williams, Common Law Right of every Freehold Tenant of a Manor to Common on the Lord's Waste (1868); (o) HW Woolrych, Treatise of the Law of Rights of Common (2 ${ }^{\text {nd }}$ ed, 1850). See also, J Scriven (ed A Brown), A Treatise on the Law of Copyholds ( $1^{\text {st }} \mathrm{ed}, 1816,6^{\text {th }}$ ed, 1882, last ed 1896).

${ }^{11}$ See: (a) Royal Commission on Common Land 1955-58 (July 1958), Cmnd 462 ('RC'); (b) B Harris \& G Ryan, An Outline of the Law relating to Common Land and Public Access to the Countryside (1967); (c) H Baker, Commons, Village Greens and Other Open Spaces; (d) R Hunter, Gardens in Towns. Law of Acquisition and Maintenance of Land for Recreation ( ${ }^{\text {nd }}$ ed, 1916) ('Hunter Gardens'); (e) P Clayden, Our Common Land, The Law and History of Commons and Village Greens (1985); (f) P Clayden, Law of Parks and Open Spaces (2009)('Clayden Parks'); (g) N Ubhi \& B Denyer-Green, Law of Commons and of Town and Village Greens (2006). See generally, Halsbury, Laws of England ( $5^{\text {th }} \mathrm{ed}$ ), vol 1 (allotments), vol 13 (commons) and vol 78 (open spaces) ('Halsbury Laws').

${ }^{12}$ See G Slater, The English Peasantry and the Enclosure of Common Fields (1907). Other general texts include: (a) GC Brodrick, English Land and English Landlords (1881); (b) Lord Eversley (formerly George Shaw-Lefevre MP), Commons, Forests and Footpaths (rev. ed, 1910), (c) ECK Gonner, Common Land and Inclosure (1912); (d) JA Yelling, Common Field and Enclosure in England 1450-1850 (1977) (and detailed bibliography therein); (e) WO Ault, Open-Field Farming in Medieval England (1972); (f) HL Gray, The English Field Systems (1915, reprinted Merlin Press, 1969); (g) C Jessel, A Legal History of the English Landscape (2011); (h) C Jessel, Law of the Manor. The Twenty First Century (2004) ('Jessel Twenty-First'); (i) C Jessel, The Law of the Manor (1998) ('Jessel Manor').

${ }^{13}$ See, in particular: (a) IS Leadam (ed), The Domesday of Inclosures 1517-18 (1897); (b) E Nasse, Agricultural Community of the Middle Ages and Inclosures of the Sixteenth Century in England (from the German by HA Ouvry)(1871); (c) WE Tate, A Handlist of Sussex Inclosure Acts and Awards (1950).
} 


\section{(a) Origin of Common Land}

To understand the nature of 'common' land - that is, communally used land - in England and Wales, it is necessary to make - at least - incidental reference to Roman and Anglo-Saxon times as well as to medieval farming methods.

- Roman Times. The Roman Empire was developed by conquest and land was allocated to Roman soldiers in conquered territories. However, certain land was also preserved for public (communal) use. Thus, land was reserved for common grazing and it acquired the title of 'common' land - with the person entitled to so use it being said to have a 'right of common.'; ; $^{14}$

- Anglo-Saxon Times. The Anglo-Saxons - who were agrarian people like their German forebears - ${ }^{15}$ (likely) adopted a similar concept. Further, great estates - being manors and honours (a collection of manors) - also (probably) existed in Anglo-Saxon times with such land being given by the various Anglo-Saxon kings to their followers for military (and ecclesiastical) services with the tenants (latin, tenens, holder of land) in such cases being treated as a 'lord of the manor' (hlafod, literally 'loaf (bread) giver'). ${ }^{16}$

In any case, after the Norman Conquest (1066), it is trite law that all land in England was held of the king (the Crown) who then parcelled it out to his adherents and, in this, the manor played an important role in respect of land tenure and rights. Scrutton described the situation, in practice, thus:

From the Conquest to the $14^{\text {th }}$ century we find the same agricultural conditions prevailing over the greater part of England. Small gatherings of houses and cots [cottages] appear as oases in the moorland and forest, more or less frequent according to the early or late settlement of the district, and its freedom from, or exposure to, the ravages of war and the punishment of rebellion. These oases, townships or vills if of some extent, hamlets if but of few houses, gather around one or more mansions of superior size and importance, the manor houses, or abodes of the lords of the respective manors.

Round each township stretch the great ploughed fields, usually three in number, open and unenclosed. Each field was divided into a series of parallel strips a furlong in length, a rod wide, four of which would make an acre, the strips being separated by ridges of turf called balks, while along the head of each series of strips runs a broad band of turf known as a headland, on which the plough is turned, when it does not by custom turn on some fellow tenant's land, and which serves as a road to the various strips in the field. These strips are allotted in rotation to a certain number of dwellers in the township, a very common holding being that known as a virgate or yardland, ${ }^{17}$ consisting of about 30 acres, in which case each holder of a virgate would have a number of strips scattered through the open fields in apparent disorder, until the key is found in the order of rotation...

The three great fields are tilled on a system of rotation of crops, each field in turn lying fallow for a year during which it is open to the cattle of all the holders of land in the fields, while the two fields under cultivation are open to the cattle from the time of harvest till the corn was sown again. At the date of Domesday (1086), the holders of land in the common fields comprise the Lord [of the manor]; the free

\footnotetext{
${ }^{14}$ Woolrych, n 10, pp 3-4 'Some parcels [of land], says Flaccus, were excepted from distribution, which either had been reserved by the author of the division for himself, or which he had granted to another. These were called common pastures, cut off, as it were, from the residue of the apportioned lands, for the benefit of neighbouring inhabitants.' Woolrych cited Siculus Flaccus (who lived, possibly, $2^{\text {nd }} \mathrm{c}$ AD) who wrote a treatise on the Legal Status of Landholding in Italy (De Condicionibus Agrorum). Woolrych also stated 'Frontinus who wrote under Vespasian [69AD - 79AD], recognises the right as clearly established; and he goes further, by stating it as a species of property, and appendant to farms, but used in common with other persons, on which account it was, in many parts of Italy, called a right of common.' Woolrych cited Sextus Julius Frontinus (35 AD -103 AD) whowrote a treatise on the Art of Surveying of which only two chapters are extant (including De Limitibus Agrorum). See also Jessel, n 12, pp 28-33.

${ }^{15}$ H Mattingly (trans), Tacitus on Britain and Germany (Penguin, 1954 rep) ,p 122 'Lands are taken into occupation, turn and turn about, by whole villages in proportion to the number of cultivators, and are then allotted in order of rank. The distribution is made easy by the vast extent of open land. They change their plough lands yearly, and still there is ground to spare...They plant no orchards, fence off no meadows, water no gardens; the only levy on the earth is the corn crop.'

${ }^{16}$ Whether manors of the post-Norman Conquest sort existed in Anglo-Saxon times has always been somewhat uncertain and tied up with a political (and emotional) issue as to whether Englishmen were free prior to the Conquest. Likely, much land in Anglo-Saxon times (i.e. post 554 $\mathrm{AD}$ ) was held by the various kings and great estates were parcelled out to their followers who, then, farmed such estates utilising the services of some free tenants as well as bound (bond) tenants (villeins) and slaves. See Scrutton (writing in 1887), n 10, ch 1 who noted generally 'The origin and history of common lands in England are inseparably bound up with the history of the manor....'. See also Woolrych, n 10, p 6; RC, n 11, App 2 (Hoskins), pp 149-50; Ubhi, n 11, p 13 and Jessel, n 12, chs 4 \& 5.

${ }^{17}$ Nasse, n 13, p 8 'uninclosed commons were still divided into yards of land, yardlands, the medieval vergatae terrae, the Anglo-Saxon 'gyrde lands".
} 
tenants, socmanni or liberi homines, when there are any; the villani or Saxon geburs, the holders of virgates or half virgates; and the bordarii or cotarii; holders of small plots of 5 acres or so, who have fewer rights, and fewer duties. Besides ploughing the common fields, the villani as part of their tenure have to supply the labour necessary to cultivate the arable land that the lord of the manor keeps in his own hands as his domain, dominicum, or demesne. There are next the meadows use for hay, divided during the growth of the crop among the villeins and other tenants by a system of shifting rotation, from which they are frequently known as 'lot meadows,, 18 and open as common pasture to their cattle from the time of hay harvest till the ensuing spring. There are also pastures specially appropriated to oxen or sheep, usually held in common by the villeins, sometimes appropriated to particular owners...Round this cultivated oasis stretch woods in which pigs of the community feed, and great moorland wastes and marshes, furnishing a poor pasture for cattle, with no boundary marking where the claims of the manor or township end, and giving rise to strayings justified as common pur cause de vicinage [by reason of neighbourhood]. ${ }^{19}$

After the Norman Conquest, therefore (if not before) there was a manorial system. One in which manorial land was owned by one person - the lord of the manor - and yet could be used as a common (communal, community) land by others, such as freemen, villeins (peasants) and slaves. Such land comprised either:

- Common fields (i.e. open fields) of arable (that is, cultivated, agricultural) land; or

- The 'lord's waste' (i.e. land being not used by the lord) with the users (the commoners) acquiring certain rights (rights of common) over the same. ${ }^{20}$

For his part, the lord of the manor (usually) retained his own land (his demesne) for his private use, although this, too, he might let out - or grant rights of common over - especially in later medieval times. Finally, it was also possible for freemen to own land and to farm it (if arable land) - or to use it communally - without the lord of the manor having any ownership (or rights of common) in the same. However, such was not manorial land, if not owned by the lord of the manor.

\section{(b) Rights of Common \& Common Fields}

The result of this was that English law recognised a 'right of common' in land. That is, an incorporeal hereditament (i.e. a legal tenure in land, not of a physical nature). One which arose where two (or more) persons,

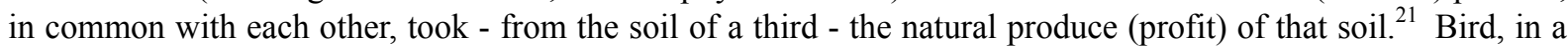
legal text in 1806, defined a right of common as follows:

The word communia, or common, as taken substantively, and used as a term of art, properly signifies a right or privilege [in] which one or more persons claim to take or use some part or portion of that which another man's lands, waters, woods etc do naturally produce... ${ }^{22}$

\footnotetext{
${ }^{18}$ Lot meadows were meadows where the tenants had their own strips and cast lots for them annually. RC, n 11, p 275 'a form of lammas land [see $n$ 34] marked off in separate portions for which the owners draw lots each year.'

${ }^{19}$ Scrutton, $\mathrm{n}$ 10, pp 1-3 who also observed that 'Large tracts of country are covered by the forests, or lands preserved for the king's hunting by the forest laws... The lands in the royal forests do not necessarily belong to the king; but all the soil within the forest bounds is subject to oppressive restrictions in its use, the welfare of the king's game and deer being the all important object. The inhabitants and tenants have common in the waste lands within the forest, except in the fence month, when the deer are breeding; no old fence at any time may stand more than 4 feet in height, and no new fence can be erected without the Crown licence, that the deer may have free run throughout the forest.' As for common in vicinage, this was no more than a licence of the lord to persons to use un-utilised land, see n 30. See also RC, n 11, App 2 (Hoskins), pp 151-4. For a useful description of the medieval open field system, and byelaws, see Ault, $\mathrm{n} 12$.

${ }^{20}$ Woolrych, $\mathrm{n} \mathrm{10, \textrm {p } 6} 6$ 'The next step on the part of these great feudatories was, to parcel out their new property among their followers and dependents, who thus became their tenants, reserving, of course, a certain large share for their own demesnes. But it happened, that as in the division of territories by the Romans, some grounds were left out of the distribution, so these lords did not include all the granted property in their division, what remained then was called the lord's waste, and as the tenant's could not feed their cattle on their own allotments, while their corn was growing, the immunity of feeding on what was waste was permitted them at certain seasons, which at length ripened into a right of common, as it is at present enjoyed.' See also Potter v Sir Henry North (1669) 1 Vent 383 (86 ER 245) at 395 'Upon the creation of manors, the lords took as much as was for their own use into their demesnes, they distributed as much as was convenient amongst their tenants; what was left was called the lord's waste, which was neglected by the lord because he had before taken into his demesnes what he had need of.' Jessel, n 12, p 63 'The Domesday Book was first of all a list of manors. With a few exceptions, the whole country was seen as being in one manor or another.' Ibid, p 71 'Each manor had a lord, who might be an institution or an individual, or an institution such as an abbey, or who might be the king.'

${ }^{21}$ Ibid, p 13 'A right of common is an incorporeal hereditament, and may be said to exist where two or more, by virtue of a grant, prescription or custom, take, in common with each other, from the soil of a third person, a part of the natural profits thence produced.'

${ }^{22}$ Bird, n 10, p 1. Elton, n 10, p 2 'A common, then, is a right of taking some part of any natural product of the land of another.' See also Halsbury Laws, n 11, vol 13, para 305.
} 
These 'rights of common' tended to be sub-divided into the following rights:

- Common of pasture

- Common of estovers (Anglo-Saxon, botes)

- Common of turbary (Latin, turbus)

- Common of piscary (fishery)
- to pasture animals on another's land; ${ }^{23}$

- $\quad$ to take wood from another's land; ${ }^{24}$

- to dig peat (or coals) on another's land; ${ }^{25}$

- to fish in another's pool or river. ${ }^{26}$

The above could be held as a right:

- appendant; ${ }^{27}$

- appurtenant $;^{28}$

- in $\operatorname{gross},{ }^{29}$ or,

- only in respect of common of pasture, in vicinage. ${ }^{30}$

Thus, common of pasture appendant was the right to graze cattle. And, common of pasture appurtenant was the right to graze animals other than cattle. Common in gross was (more) a contractual right, as opposed to a real one, not being linked to land. Common in vicinage (strictly) was a licence rather than a right. More modern definitions of these rights (in simplified English) were provided by the Royal Commission on Common Land in $1958 .^{31}$ These rights of common still exist and a subsequent article will consider them (as well as rights in respect of minerals). However, it be noted that, by the early $20^{\text {th }}$ century, most rights of common (of pasture, estovers, turbary and piscary) had either lapsed - because farmers did not want to pasture their animals together 32 - or they were of little value (e.g. gathering wood or peat to heat a commoner's house had given away to

${ }^{23}$ By 'pasture' is meant the right of such animals to feed (fodder) on such land. See also Bird, $\mathrm{n} 9, \mathrm{p} 1$. The feeding of pigs on mast and acorns in a commonable wood was called 'pannage'. See Elton, n 10, p 25. Also, Hall, n 10, ch 13 and Peek, n 10, p 323.

${ }^{24}$ Estovers were sub-divided into 3 kinds: (a) house bote (to repair a house or to use for fuel therein - the latter could also be called fire bote); (b) plough bote (to repair farm equipment); (c) hedge bote (to repair fences and inclose fields). See also Bird, n 10, pp 2, 19-23 and Woolrych, n 10, p 14 and ch 8. Estovers - probably from the Anglo-Norman fovere, to keep warm (or estouffer, to furnish - in Anglo-Saxon, botan) could also include other plants for fuel, see Elton, n 10, p 26. Also, Hall, n 10, ch 20 and Hunter, n 10, p 4. For definitions of rights of common, see also DR Denman et al, Commons and Village Greens (1967), App 2.

${ }^{25}$ See Bird, n 10, pp $1 \& 23-4$. Woolrych, n 10, p 15 'The want of fuel pointed out to them [tenants] the further necessity of digging up the turves on the waste, and permission was granted them to do this, on condition of their leaving sufficient pasturage for the cattle accustomed to feed there: thus was the rise of the common of turbary.' Ibid, ch 9. See also Hall, n 10, ch 19.

${ }^{26}$ Ibid, p 1 . Woolrych, n 10, p 89 'Common of fishery is a right...to take fish in the water of a third person....'. See also Bird, n 10, pp $1 \& 4-5$ and Hall, n 10, ch 18 .

${ }^{27}$ e.g. for common of pasture appendant, Woolrych, n 10, p 19 'Common of pasture appendant is a right inseparably annexed to the possession of ancient arable land, by which a man is entitled to feed the beasts which plough and manure such land, and are levant [standing] and couchant [lying] thereon, in the lord's waste.' See also Ibid, p 15 and ch 3. Scrutton, n 10, ch 2 (common appendant only applies to commonable cattle, horses, oxen, cows and sheep). Such a right arose by way of grant. See also Bird, n 10, pp 4-9 and Hall, n 10, ch 14.

${ }^{28}$ e.g. for common of pasture appurtenant, Woolrych, n 10, p 47 'Common appurtenant, in its fullest latitude, is a right ... to feed his commonable and other cattle in the soil of a third person, such cattle being levant and couchant [standing up and lying down] within the township, or on the land in respect of which the common is claimed.' See also Ibid, p 15. Scrutton, n 10, ch 2 'Common appurtenant... covers a right to common with animals that are not commonable, such as pigs, donkeys, goats and geese; or a right to common claimed for land not anciently arable, such as pasture, or land reclaimed from waste within the time of legal memory, or for land that is not freehold, but copyhold.' See also Bird, n 10, pp 10-4 and Hall, n 10, ch 15.

${ }^{29}$ e.g. for common of pasture in gross, Woolrych, n 10, p 60 'Common in gross...is the right [of] a man to depasture his cattle in the ground of a third person...'. See also, Ibid, p 15. Scrutton, n 10, p 55 'Common in gross is the personal servitude, as opposed to the two common rights attached to land...'. See also Bird, n 10, pp 14-7 and Hall, n 10, ch 17. Hunter, n 10, p 3 (writing in 1902), p 3 noted that common in gross, even in his time, was 'comparatively rare.'

${ }^{30}$ Woolrych, $\mathrm{n} \mathrm{10, \textrm {p }} 16$ 'vicinage...was where the inhabitants of two townships or vills intercommoned in wastes contiguous to each other, so that the cattle of either respectively strayed into the pastures belonging mutually to both.... it has been long settled that such a custom is only an excuse for a trespass, and that the law winks at it to prevent suits in a champaign [i.e. champion, rural - as opposed to woodland] country.' See also Ibid, ch 4. Also, Bird, n 10, pp 17-8, Elton, n 10, p 12, Hall, n 10, ch 16 and Hunter, n 10, ch 5. Ibid, p 54 'common pur cause de vicinage is now comparatively rare.' See also RC, $\mathrm{n} 11, \mathrm{p} 169$.

${ }^{31}$ See RC, n 11, pp 272-6. See also ch 4 (the commoners and their rights). For the present position on rights of common see Halsbury Laws, $\mathrm{n}$ 11, vol 13, para 330 et seq.

32 Scrutton (writing in 1887) noted, n 10, p 169 that 'in the present days of high farming and careful breeding good cattle are not fed on the commons; the rights of common are but little used; and 'sufficiency of pasture', which is estimated by recent user, is a fast diminishing quantity.' Today, grazing cattle in common is precluded (in effect) by sanitary requirements for the same. Further, it should be noted that all rights of common were only intended for the tenant's own (necessary) use - and not to be on-sold, see Elton, n 10, p 106 and Peek, n $10, \mathrm{p} 23$. See also Lord Eversley (in 1910), n 12, pp 1-2 and Hunter, n 10, pp 4, 28. As to the irrelevancy of rights of common of pasture appendant and of vicinage, see Ubhi, n 11, pp 36, 40 . 
cheap coal); also, rights of common of pasture appendant and of vicinage are no longer relevant. ${ }^{33}$ For present purposes, these 'rights of common' should be distinguished from the land itself which could be farmed either individually by one farmer or communally, that is, by a number of farmers. The latter system comprised (as described in (a) above) a 'common field' system. It was also, sometimes (alternatively) referred to as:

- an 'open commonable intermixed field' system;

- an 'open field' system;

- 'strip farming'; or

- lammas land (although this is more restricted). ${ }^{34}$

Why such a distinction should be made is that the Inclosure Acts 1733-1868 - which will be discussed - were, mainly, concerned with inclosing common field (arable) land while subsequent Acts - such as the Commons Act 1876 - were, mainly, concerned with inclosing manorial waste (i.e. non arable land), since few common fields existed in England and Wales after 1876.

\section{(c) Inclosing Common Land - Prior to 1235}

Although the owner of land (the lord of the manor) had full title to his land - including: (i) common fields; (ii) manorial waste; and (iii) his demesne - this was circumscribed by rights of common which he (or prior owners) had previously granted or permitted. ${ }^{35}$ Thus, the issue soon arose after the Norman Conquest (1066) whether the lord could inclose common fields or manorial waste land without the consent of the commoners (if, with their consent, there was no legal problem). Why the lord of the manor would want to do this was, usually, based on hard economics. An open (common) field system meant many persons using the land and this (often) resulted in less productivity (and much more labour) than if the same was inclosed. However, in medieval times, inclosure was a charged 'political' issue - especially prior to the $18^{\text {th }}$ century. As Woolrych noted (in 1850), the arguments 'for and against' inclosure were fairly clear and he summarised them:

On the one hand, it has been argued, that the trespasses and intrusions on common fields are great abuses; that the manure spent on them, not being properly spread, is exhaled and wasted by the weather; that the rot is a frequent disease among commonable sheep; that the fleece of such is not so good as though [if] they had been bred on lands inclosed; that the attendance required on the owner's part is greater; that the profit of cattle kept on inclosed lands far exceeds that derived from such as are kept on commons; and that the rich are enabled to oppress the poor, by overcharging the wastes.

It was said, on the contrary, that inclosures are the parents of beggary and depopulation; that through them many houses and farms have become untenanted; that it is a great hardship to force parties into an agreement; and that many would, by this system of tillage, be deprived of their common benefit. ${ }^{36}$ (wording divided for ease of reference)

\section{Thus, the inclosure of land was a 'political' issue until the $18^{\text {th }}$ century when it was generally recognised that it secured better productive use of the soil.}

\section{(d) Inclosing Common Land - 'Approvement' pre-1235}

The process of inclosing waste in England (likely) commenced early on in medieval times. The process at common law was one of 'approvement'- the word meaning appropriation with, also, the connotation of

\footnotetext{
${ }^{33}$ As for turbary, Elton, $\mathrm{n} 10$, pp 97-8 indicated (writing in 1886) that this right had 'entirely fallen into disuse, or is only exercised for unwarranted purposes.' Coal was also cheap, Peek, n 10, p 37. As well as these rights of common, there were also mineral rights.

${ }^{34}$ Nasse, n 13, p 4 'They [common fields] were designated 'open commonable intermixed fields,' and also 'lammas lands' because 'lammas' is the fete Petri ad vincula [festival of St Peter in Chains] on the $1^{\text {st }}$ August - or, according to the old calendar by which the reckoning was then taken, the $13^{\text {th }}$ August - which was the period of the commencement of the common rights of pasturage.' See also Elton, n 10, p 26 (lammas land) and Ubhi, n 11, p 25. However, as the RC, n 11, p 45 noted, lammas land tended to be distinguished from common (open) arable fields since the latter were only open for part of the year 'lammas or half-year lands indicating that they are commonable for only part of the year.' Also, Ibid, p 275 (lot meadow) 'a form of lammas land...marked off in separate portions for which the owners draw lots each year.' Ibid, p 169.

${ }^{35}$ Woolrych, n 10, p 145 'Although lords of manors had, in the first instance, an absolute property over their wastes, yet...they sacrificed a portion of their dominion for the benefit of their tenants, by granting them certain privileges arising out of those wastes, retaining, at the same time, the ownership of the soil.' As RC, n 11, App 2 (Hoskins), p 154 noted, the idea that the lord of the manor owned the manorial waste and common land was entrenched by the time Bracton wrote (c.1250).

${ }^{36}$ Ibid, pp 8-11. See also Considerations concerning Common Fields and Inclosures (London, 1653).
} 
improvement. ${ }^{37}$ The English courts permitted inclosure provided the lord of the manor left - for the commoners sufficient common land with egress (exit) and regress (re-entry). ${ }^{38}$ Blackstone (1768) defined the process of approvment thus:

the lord [of the manor] may approve, that is, enclose and convert to the uses of husbandry (which is a melioration or approvement) any waste grounds, woods, or pastures, in which his tenants have common appendant to their estates; provided he leaves sufficient common [land] to his tenants, according to the proportion of their land. ${ }^{39}$

In later centuries, when the law prior to 1235 was long forgotten, whether approvement could validly exist at common law was disputed by various later writers. For example, Coke was uncertain whether a right such existed - though he seems to have come out on the basis that it did. ${ }^{40}$ In any case, legislation intervened in respect of inclosure by 1235 .

In conclusion, the inclosure of land by a lord of the manor by way of 'approvement' was upheld (it seems) by the common law pre-1235.

(e) Inclosing Common Land - Statute of Merton 1235

The Statute of Merton (1235), chapter (i.e. section) 4 (now repealed) enabled lords of the manor to inclose their land, providing they otherwise left sufficient common land for the commoners. ${ }^{41}$ This statute, being the first inclosure Act, stated that:

because many great men in England (which have enfeoffed knights and their freeholders of small tenements in their great manors) have complained that they cannot make their profit of the residue of their manors, as of wastes, woods, and pastures, [and] whereas [i.e. although] the same feoffees have sufficient pasture, as much as belongeth to their tenements;

it is provided and granted that whenever such feoffees do bring an assize of novel disseisin for their common of pasture, and [provided that] it is acknowledged before the justices that they have as much pasture as sufficeth for their tenements, and that they have free egress and regress from their tenement unto the pasture, then let them be contented therewith, and they on [i.e. about] whom it was complained shall go quit as of much as they have made their profit of their lands, wastes, woods, and pastures...

if it be certified by the assize that the plaintiffs have sufficient pasture with ingress and egress, as before is said, let the other make their profit [i.e .inclose] of the residue and go quit of the assize. ${ }^{42}$ (wording divided for ease of reference)

\section{The Statute of Merton 1235, therefore, enabled lords of manors to inclose their land by way of 'approvement.' \\ (f) Inclosing Common Land - Statute of Westminster 1285}

The Statute of Merton 1235 only applied to knights (milites) and to free tenants (libere tenentes) with rights of common in the relevant manorial wastes, woods and pastures (vastis, boscis et pasturis) and who had acquired such by way of a grant from the lord of the manor. This restriction the Statute of Westminster (1285), chapter (section) 46 (now repealed) sought to remedy. ${ }^{43}$ Woolrych noted:

\footnotetext{
${ }^{37}$ C Sweet, A Dictionary of English Law (1882), p 58 (approve) 'By the Statute of Merton [1235]...the lord of a manor may enclose portions of the waste lands, if they are subject only to a right of common of pasture, and provided he leaves sufficient common for those entitled thereto. The is called 'approving', from appropriare, to appropriate.'

${ }^{38}$ Woolrych, n 10, p 155 'approvement, by which part of the waste is inclosed by the lord for his own benefit, he leaving sufficient common, with egress and regress for the commoners.'

${ }^{39}$ Blackstone, n 9, vol 3, pp 240-1.

${ }^{40}$ Woolrych, n 10, pp 155-6. See also Scrutton, n 10, p 40. He thought that, probably, there was a common law right prior to the Statute of Merton 1235 and that the latter was declaratory of the same). Ibid, p 67. So did Elton, n 10, p 180, who also stated as to the present position in his time (1868), p 172 'there is no doubt that the lord of the manor has the right to take for his own benefit the overplus of waste, leaving sufficient pasture for the commoners.' See also Cooke, n 10, p 66 and Hall, n 10, ch 23.

${ }^{41}$ Statute of Merton (1235), 20 Hen 3 c 4 . The Act 3 \& 4 Edw VI (1550), c 3 cited and confirmed the Statutes of Merton and Westminster. Woolrych, n 10, p 156 'It was... enacted by the Statute of Merton, that whenever an assize of novel disseisin should be brought by the feoffees of lords of manors, and it should appear before the justices that they had sufficient pasture for their tenements, and free egress and regress for their tenements to the pastures, the parties complained of should go quit of as much as they might have made their profit of the lands, wastes and pastures.' See also Scrutton, n 10, p 56 'The Statute of Merton in 1236 gave a Parliamentary sanction to the enclosure of wastes by a lord of the manor...' See also, Elton, n 10, pp 175 et seq. and Hunter, n 10, p 10.

${ }^{42}$ For an analysis of the Statute of Merton 1235, ch 4, see Coke, n 9, vol 2, pp 84-8.

${ }^{43} 13$ Edw 1 c 46 . For the wording see also Hunter, n 10, pp 10-1.
} 
By [this Act], which recited, that because in that Act [i.e. the Statute of Merton 1235] no mention was made of approvements between neighbour and neighbour, and that by reason of a doubt whether that statute applied only to lord and tenant, many lords of wastes, woods, and pastures had been hindered from making approvements by the contradiction of neighbours, though they had sufficient pasture; the [Statute of Merton 1235] was declared to extend not only to the lord's tenants, but also to neighbours; and although a neighbour properly is one qui una in eodem vico est [who is in the same vicus, town], yet, according to Lord Coke, the word vicinus, in this Act, is taken for a neighbour, though he dwell in another town, so [long] as the town and the common adjoin. ${ }^{44}$

\section{The Statute of Westminster 1285, therefore, enabled a lord of the manor, if his waste was also used as a common pasture by other manors, to inclose the same by approvement.}

\section{(g) Inclosing Common Land - Up to $16^{\text {th }}$ Century}

The effect of the Black Death (1351) was to reduce the number of agricultural labourers in England and Wales. As a result, lords of the manor (often) ceased to cultivate most of their demesne land. Instead, they leased it out. Thus, their connection with the land - and the commoners using it - was less. Then, after the Wars of the Roses (1455-87), there was an increasing concentration in England and Wales on trade - including in the agricultural sector. In particular, sheep farming was in vogue, as a means of securing higher returns than would otherwise be obtained from tilling the land. The combined effects of these matters - as well as other events - resulted, from the late $15^{\text {th }}$ century, in the inclosing of common (i.e. arable, cultivated) land at a great rate, together with de-population of the land. Various Acts, unsuccessfully, sought to check what was regarded as a social evil since it resulted in a migration to the cities and towns and a landless, less obedient, lower class. ${ }^{45}$ Legislation which sought to perpetuate tillage and prevent de-population included the following Acts:

- Depopulation Act 1489. A depopulation Act of 1489 indicated the problems of changing the open field system to one of pasture. ${ }^{46}$ It provided that all occupiers of 20 acres (or more) of land that had been tilled in the prior 3 years, were required to maintain tillage, on pain of forfeiting to the lord of the manor one half of the profits of such land; ${ }^{47}$

- Acts of $1516 \&$ 1534. An Act of 1516 sought to uphold tillage and husbandry in parishes where the same was, for the most part, practised ${ }^{48}$ and another of 1534 sought to restrain sheep farming, ${ }^{49}$

- Depopulation Acts 1536-56. There were further depopulation Acts in $1536,{ }^{50}$ in $1552^{51}$ and in $1555-6 ;^{52}$

\footnotetext{
${ }^{44}$ Woolrych, n 10, pp 156-7. See also Scrutton, n 10, pp 60-1. Blackstone, n 9, vol 3, p 241 'The [Statute of Westminster 1285, ch 46] extends this liberty of approving, in like manner, against all others that have common appurtenant, or in gross, as well as against the tenants of the lord, who have their common appendant...'. See also Bird, n 10, p 35, Elton, n 10, p 189-90 and Hall, n 10, ch 23. For an analysis of the Statute of Winchester 1285, ch 46, see Coke, n 9, vol 2, pp 472-7.

${ }^{45}$ Described in Scrutton, n 10, ch 4. See also Brodrick, n 12, ch 2. See also T More, Utopia (quoted Jessel, n 12, p 97) 'your sheep, that were wont to be so meek and tame, and so small eaters, now, as I hear say, become so great devourers, and so wild, that they eat up and swallow down the very men themselves. They consume, destroy, and devour whole fields, houses, and cities.'

${ }^{46} 4$ Hen VII (1489), c 19 'Our king and sovereign lord...remembreth that...great inconveniences do daily increase by desolation and pulling down, and wilful waste of houses and towns within this realm and laying to pasture lands, which customably have been used in tillage, whereby idleness, which is the ground and beginning of all mischiefs, daily does increase. For where in some towns two hundred persons were occupied and lived by their lawful labours, now there are occupied two or three heardmen, and the residue fall into idleness, the husbandry, which is one of the greatest commodities of this realm is greatly decayed..' See also Nasse, n 13, p 75 and RC, n 11, App 2 (Hoskins), pp 155--8.

${ }^{47}$ See also 6 Hen VII (1515) c 5 (a temporary Act almost identical with this Act). See also Nasse, n 13, p 76.

487 Hen VIII (1516), c 1. The Act applied to parishes where the most part was (or were) used and occupied to tillage and husbandry. In such places, if any person 'shall decay a town, a hamlet, or house of husbandry, or convert tillage into pasture' and had not within the following year made the land again 'meet and convenient' for people to dwell and inhabit the same, and have use and therein to exercise husbandry and tillage, he forfeited one half of his land to the lord of the manor, until the offence was reformed. Land converted to pasture must again be tilled 'after the manner and usage of the country where the said land lay.' See also 6 Hen VIII c 5 (1515); Scrutton, n 10, p 77 and Nasse, n $13, \mathrm{p} 76$.

4925 Hen VIII (1534), c 13 'Sundry persons have of late daily studied how to gather into few hands great multitude of farms and great plenty of cattle, and in especial sheep, putting such land as they can get to pasture, and not to tillage, whereby they have not only pulled down churches and towns and inhanced the old rates...so poor men are not able to meddle with it...it is thought that the great occasions that move and provoke those greedy and covetous people...is only the great profit that comes of sheep.' It is enacted that, with certain exceptions, no one may keep more than 2,000 sheep under a penalty of $3 \mathrm{~s} 4 \mathrm{~d}$ per sheep per annum, half of the fine going to the Crown and half to the informer. No man, also, might have more than 2 farms and these should not be in the same parish. See also Scrutton, n 10, 77.

${ }^{50} 27$ Hen VIII (1536), c 22 recited 4 Hen VII c 19 (see n 46) and stated that it had been enforced only in lands held immediately of the king. It provided for the king to have the moiety of the profits of those lands already converted for tillage to pasture since 3 years before the earlier Act until the owner built a house to inhabit and converted the pasture to tillage again. Also, for the king to take the moiety of the issues of those lands hereafter to be converted, if the immediate lord do it not within a year, until the owners had built a tenement for every 50,40 or 30 acres
} 
- Cottagers Holdings Act 1589. In 1589, there was an Act for the protection of Cottagers' Holdings and Rights of Common; ${ }^{53}$

- Depopulation Acts 1597. There were further depopulation Acts in $1597{ }^{54}$ and, again, in $1597 . .^{55}$ The latter Act was not to be repealed until 1863 (an Act of 1623 repealed the earlier depopulation Acts referred to). ${ }^{56}$

Scrutton summed up the position as to agricultural land in England at the end of the $16^{\text {th }}$ century:

The century shows great inroads on the waste lands and commons by men who were making their parks, and by great graziers seeking pasture for their flocks, and shows that such enclosures were not carried out with any regard for the interests of the poor or the surplus population they displaced. ${ }^{57}$

In conclusion, despite legislation, there was extensive inclosure of land from the $15^{\text {th }}$ century, often, to promote sheep farming.

\section{(h) Inclosing Common Land: $17^{\text {th }}-19^{\text {th }}$ Centuries}

In the first half of the $17^{\text {th }}$ century, there was an increasing inclosure of fens and forests to create more farming land. ${ }^{58}$ However, even by the late $18^{\text {th }}$ century, much of England still operated a common field system, as noted by Scrutton:

each village or township [had], sometimes two or four, usually three of such [open] fields, divided by landmarks, broad strips of grass called headlands, and balks [i.e. banks] of turf, into narrow parallel strips, divided among the inhabitants of the village, who held their land scattered about among the field. These fields could only be tilled on a customary system of agriculture, and were subject to customary [i.e. common] rights of fallow and common pasture. ${ }^{59}$

By the $18^{\text {th }}$ century, there was less opposition to inclosure by commoners since it was generally recognised that such resulted in greater productivity. ${ }^{60}$ In this period from the $16^{\text {th }}-18^{\text {th }}$ centuries, the inclosure of common fields was made pursuant to the:

- consent of the commoners (including where the lord of the manor 'bought out' a commoner's rights); or

- the Statute of Merton 1235 and the Statute of Westminster 1285 (see (e) and (f) above).

and reconverted the pasture to tillage. Also, that the land should be tilled 'according to the nature of the soil and the course of husbandry used in the country where any such lands do lie.' See also 27 Hen VIII (1536), c 28. Persons to whom monastic lands had been granted by Henry VIII were required to maintain yearly as much of the land in tillage and husbandry as had been commonly so used within the preceding 20 years, under a penalty of $£ 613 \mathrm{~s}$ and $4 \mathrm{~d}$ per month. See also Scrutton, $\mathrm{n} 10, \mathrm{p} 77$.

${ }^{51} 5$ \& 6 Edw VI (1552), c 5. The Act required that so much land be tilled yearly in any parish as had been tilled at any time since the accession of Henry VIII (1509-47) with a penalty of 5s per acre per annum. See also Scrutton, n 10, p 90.

522 \& 3 Philip \& Mary (1555-6), c 2. This confirmed the original depopulation Act of 1489 and made it apply to all houses with 20 acres of land, whether the land was in tillage or not. Commissioners were appointed to enquire into all grounds converted into pasture to see to the re-edifying of houses and the reconversion of pasture into tillage. Rents increased on the conversion of tillage into pasture were to be abated and re-edified houses were to be let with 20 acres of land or 10 acres if the owner had no more. The penalty of laying land down into pasture was, again, fixed at $5 \mathrm{~s}$ per acre per annum, half to be paid to the Crown, half to the informer. See also 5 Eliz (1563) c 2 and Scrutton, n 10, p 93.

${ }^{53} 31$ Eliz (1589) c 7 (rep 1775). The Act prohibited the letting of cottages to agricultural labourers with less than 4 acres of land under a penalty of $40 \mathrm{~s}$ per cottage per month, or the occupation of one cottage by more than one family, under a penalty of $10 \mathrm{~s}$ per month. The amount of land attached to cottages let to countrymen following other occupations was also regulated. See also 35 Eliz 1 c 6 (1593) which the RC, n 11, p 29 thought was the first form of legislation to protect commons.

$5439 \mathrm{Eliz}$ (1597) c 1.The preamble stated that, in late years, more than in the past, sundry towns, parishes and houses of husbandry had been destroyed and become desolate. All prior Acts for the re-edification of houses were repealed. It was enacted that, when houses of husbandry had been decayed for more than 7 years, half the number must be re-built, and 40 acres of land allotted to them, unless the property had been sold meanwhile. In that case the purchaser needed only to re-build one quarter of the decayed houses. When houses had been decayed within the prior 7 years they were to be re-built. See also Scrutton, $\mathrm{n} 10, \mathrm{p} 94$.

5539 Eliz (1597) c 2. The preamble stated that, from the $7^{\text {th }}$ year of the reign of Henry VII [1492], to the $35^{\text {th }}$ year of the current reign [1593] there had always been in force some Act for the maintenance of tillage. However, in the latter year, all such laws were discontinued. In consequence in the period 1593-7 'there have grown many more depopulations by turning tillage into pasture than at any time for the like number of years heretofore.' The Act enacted that lands converted from tillage to pasture were to be re-converted within 3 years and that lands now in tillage were to remain so, under a penalty of 20 s per acre per annum.

${ }^{56} 21 \mathrm{Jam}$ I c 11.

${ }^{57}$ Scrutton, n 10, p 100.

${ }^{58}$ Ibid, ch 5. See also RC, n 11, App 2 (Hoskins), pp 161-65.

${ }^{59}$ Scrutton, n 10, p 113.

${ }^{60}$ For the problems of strip farming see Scrutton, n 10, ch 6. 
As well as these methods of inclosure - from the reign of Elizabeth I (1558-1603) - local Acts were passed to inclose land. ${ }^{61}$ And, from the reign of Charles II (1660-85), private Acts were passed to inclose land. Pursuant to such legislation, commissioners (i.e. independent experts) were appointed to undertake the inclosure of lands and confirm the agreement of the commoners to the same. ${ }^{62}$ In respect of private inclosure Acts in particular, there were a huge number. However, this legislative process was problematic - being time consuming ${ }^{63}$ as well as expensive. ${ }^{64}$ As a result, from the late $18^{\text {th }}$ century, general legislation was enacted, to expedite and simplify matters:

- Inclosure Act 1773. An Act of 1773 (which is extant) provided for the cultivation of common fields (see (i) below); ${ }^{65}$

- General Inclosure Act 1801. In 1801, a General Enclosure Act was passed which was promoted by the Board of Agriculture (1793-1819). This legislation (repealed in 1899) comprised a consolidation Act and it applied generally many sections to be found in prior private inclosure Acts. However, this Act did not deal with common (open) fields. Only with commons where the soil was part of the lord of the manor's waste. ${ }^{66}$ Also, the process for inclosure laid down by the Act was cumbersome since the necessity for a separate local Act as well was required; ${ }^{67}$

- Common Fields Inclosure Act 1836. An Act of 1831 dealt with the inclosure of waste. ${ }^{68}$ Later, the Common Fields Inclosure Act 1836 was passed. It was designed to further simplify and facilitate the enclosure of open and arable fields (i.e. common fields) in England and Wales. ${ }^{69}$ Pursuant to this legislation, two thirds in number (and value) of the owners of common fields might appoint Inclosure Commissioners for the purpose of carrying out inclosure as if the same had been authorised by a special (i.e. a private) Act. And, if seven-eighths of the owners of the land consented, inclosure could be carried out without the appointment of such commissioners; ${ }^{70}$

${ }^{61}$ See Elton, n 10, p 151. He referred to 13 Eliz c 25 (1571, reclamation of certain marshes). See also 15 Car 2 c 17 (1675, waste lands within Bedford Level) and 12 Anne c 4 (1712, waste lands in West Riding, Yorkshire).

${ }^{62}$ Scrutton, n 10, p 133. Gonner, n 12, p 58, noted that inclosure by way of private Act began systematically from the time of Queen Anne (1702-14) and increased greatly in that of George I (1714-27).

${ }^{63}$ Ibid, p 142 'The process of inclosure by private Acts was fraught with inconveniences and had in many cases unfortunate results. The consents of a large majority, four-fifths, of the persons having common rights, of the lord, and of the person entitled to the tithes, were necessary to induce Parliament to sanction the enclosure. Anyone of these classes could defeat the measure, and their interests were antagonistic.'

${ }^{64}$ Ibid, p 144.

${ }^{65} 13$ Geo 3 c 81 (1773). See also Scrutton, n 10, p 152 and Peek, n 10, pp 196-7. Acts of 1756 (29 Geo 2 c 36 ) and of 1758 (31 Geo 2 c 41 ) allowed owners of wastes (or of common fields), with the agreement of the major part in number and value of the commoners, to enclose wastes (or common fields) in severalty [i.e. individually] for the growth (or preservation) of timber for such time and in such manner and on such conditions as should be agreed. See also Woolrych, n 10, pp 315-6 and Bird, n 10, pp 45- 55.

${ }^{66} 41 \mathrm{Geo} 3$ (1801), c 109, 'An Act for consolidating in one Act certain provisions usually inserted in Acts of inclosure, and for facilitating the mode of proving the several facts usually required in the passing of such Acts.' It was amended by $1 \& 2$ Geo IV (1821), c 23. See also Scrutton, n 10, pp 154-5, Gonner, n 12, ch 2; Scriven, n 10, p 327 and RC, n 11 (Ivor Jennings QC), p 174.

${ }^{67}$ See Bird, n 10, pp 82-100 for the process of obtaining an Act of Parliament for inclosing common and other waste lands. Also, pp 101-6 (abstract of the General Inclosure Act 1801). Peek, n 10, p 270 'the necessity for a separate local Act for each inclosure still remained; the statute only aimed at making the respective Acts more easily procurable.' See also Ibid, pp 417-20. For criticism of the inclosure commissioners acting under this Act, see Coventry, $\mathrm{n} 10$.

${ }^{68} 1 \& 2$ Will IV (1831) c 42. The churchwardens and overseers of a parish could enclose up to 50 acres of waste, with the consent of the lord of the manor and the majority of the owners of common rights, for the relief of the poor rates (or let the land so enclosed to poor and industrious persons). See also $4 \& 5$ Will IV (1834) c 30, an Act to facilitate the exchange of intermixed lands in common fields, by removing difficulties caused by some owners being minors, insane etc. See also Scrutton, n 10, pp 155-6 and RC, n 11, App 2 (Hoskins), p 164-5 and (Ivor Jennings QC), p 174.

${ }^{69} 6$ \& 7 William IV (1836) c 115. See also Scrutton, n 10, pp 156-7; Elton, n 10, p 153 and Peek, n 10, pp 197-8.

${ }^{70}$ The Act was stated not to authorise the inclosure of common fields within 10 miles of the centre of London, within one mile from the centre of a town of 5000 inhabitants, within 1 and $1 / 2$ miles from one of 15,000 inhabitants, within 2 miles from one of 30,000 inhabitants, within 2 and $1 / 2$ miles from one of 70,000 inhabitants or within 3 miles from one of 100,000 inhabitants. An Act of $3 \& 4$ Vict (1840) c 31 extended the scope of the Act to lammas meadows. It also provided that persons dis-satisfied with awards under the preceding Act forfeited their right of appeal if they took possession of the lands allotted to them. See also Scrutton, n 10, pp 156-7. 
- Inclosure Act 1845. In 1845, there was passed an Act for the Enclosure of Commons in England and Wales (still extant, see (i) below). This Act was further restricted in its ambits by the Metropolitan Commons Act $1866^{71}$

Besides these Acts there were a (vast) number of private Acts providing for the inclosure of land in specific parishes. Indeed, Slater, in his work, estimated there were some 1,385 private Acts passed in the period 1727-1845 that provided for inclosure. ${ }^{72}$ He set out many of these private Acts (in the period 1724-1901) in an appendix to his work. It should also be noted that many inclosures would not have required legislation - whether a general, local or a private act - since the landowner (lord of the manor) and the relevant commoners of common fields otherwise agreed to the same. Indeed, given the cost of the legislative process, there was a real incentive for the lord of the manor to buy out (or force out) commoners - whether those tilling common fields or those with rights of common (pasture etc) on manorial waste.

\section{(i) Inclosure Acts of 1773 \& 1833}

In 1773, another general inclosure Act was passed. As Woolrych noted, the Inclosure Act 1773 (the '1773 Act') was prompted by public concern as to a lack of corn needed to maintain the increasing British population. ${ }^{73}$ Thus, inclosure was seen as a very positive act since it was thought (and, indeed, did) increase crop yields. The 1773 Act - which Act is still extant - is entitled an 'Act for the better cultivation, improvement, and regulation of the Common Arable Fields, Wastes and Common of Pasture in the Kingdom. ${ }^{74}$ Section 1, 'How open arable lands shall be fenced etc, ${ }^{75}$ provides:

In every parish or place in this kingdom where there are open or common field lands,

all the tillage or arable lands lying in the said open or common fields shall be ordered, fenced, cultivated and improved in such manner by the respective occupiers thereof, and shall be kept, ordered and continued in such course of husbandry, and be cultivated under such rules, regulations and restrictions,

as three-fourths in number and value of the occupiers of such open or common field lands in each parish or place, cultivating and taking the crops of the same, and having the consent of the owners in manner herein-after mentioned, and likewise the consent of the rector, impropriator or tithe owner, or the lessee of either of them respectively, first had in writing,

shall, at a meeting (in pursuance of notice for that purpose, in writing under the hands of one-third of such occupiers, to be affixed on one of the principal doors of the parish church, chapel or place where meetings have been usually held for such parish or place respectively, [21] days at least before such meeting, specifying the time and place of such meeting), by writing under their hands, constitute, direct and appoint, and which notice any of such occupiers are hereby authorised and impowered to give. ${ }^{76}$ (wording italicised and divided for ease of reference)

Thus, this Act only covers land which comprises 'open or common field lands' (the word 'open' being a synonym for 'common'). Inclosure can only be made if $3 / 4 \mathrm{rds}$ 'in number and value' of the commoners (i.e. the tillers of the common fields) agree, as well as the owner of the land (the lord of the manor). The consent of the 'rector, impropriator or tithe owner' (or the lessee of either of them) is also required. Other sections of the Act still extant are, mainly, administrative in nature. They deal with the following:

- $\quad$ rules not to be binding longer than 6 years (s 2);

- $\quad$ appointment of a field master (reeve) to supervise fencing etc (s 3);

- $\quad$ expenses (s 4);

\footnotetext{
${ }^{71} 29$ \& 30 Vict c 122, s 5 further restricted the Inclosure Act 1845 (no application for the inclosure of any common or waste land within the metropolitan police district (MPD) could be entertained by the Inclosure Commissioners). The purpose of this was to protect parks and open spaces within 15 miles of London. See also Scrutton, n 10, pp 162-3 and Elton, n 10, pp 163-4.

${ }^{72}$ Elton, $\mathrm{n} 10$, pp 154-5 estimated that there were about 2,000 private Acts passed before the General Inclosure Act 1801 and about the same number between 1801-45. See also Peek, n 10, pp 67-8.

${ }^{73}$ Woolrych, n 10, p 317 'In the year 1773, when Great Britain had suffered considerably for want of sufficient corn to maintain her population, the public attention was strongly urged towards inclosures, and the legislature was thought fit to pass an act for the better cultivation, improvement, and regulation of common, arable fields, wastes and pastures.' See also Scrutton, n 10, p 153 and RC, n 11 (Ivor Jennings QC), p 174 .

${ }^{74}$ See generally, Elton, n 10, p 157 et seq.

${ }^{75} 13$ Geo 3 c 81 . See also Woolrych, n 10, p 317 et seq.

${ }^{76}$ Ibid, $\mathrm{s} 1$.
} 
- occupiers of common fields in every parish to assemble and elect field reeves (s 5);

- new field reeves to be appointed in place of those who die (or refuse to attend)(s 6);

- occupiers at meetings to settle the time of opening common fields (s 7);

- cottagers etc not to be excluded from having a right of common (s 8), $;^{77}$

- part of common fields may be allotted to cottagers etc (s 9);

- $\quad$ saving of rights to persons with separate sheep walks etc (s 10); ${ }^{78}$

- balks, slades etc may be ploughed with the consent of lords of the manor etc (s 11); $;^{79}$

- balks etc used as roads (public or private) not to be ploughed (s 12);

- persons having a licence to plough balks etc to lay down other land as common land (s 13);

- boundary stones to mark balks etc ploughed (s 14);

- lords of manor etc may lease $1 / 12$ part of wastes with consent of 3/4rds of commoners (s 15);

- $\quad$ assessments to be levied for the improving of wastes with stinted commons (s 16$) ;{ }^{80}$

- owners etc at meetings may postpone opening of stinted commons (s 17);

- $2 / 3$ rds of commoners (with the consent of the lord of the manor) may direct the opening (and shutting) of stinted commons (s 18);

- $\quad$ proviso in respect of persons not consenting to the above regulations (s 19); ${ }^{81}$

- persons with right of common in stinted commons may depasture sheep instead of other cattle (s 20);

- $\quad$ rams not to remain on wastes between $25^{\text {th }}$ August $-25^{\text {th }}$ November (s 21);

- agreements may be signed on behalf of owners under a disability etc (s 22);

- tithes of commons during the 6 years to be let only for half yearly, or yearly, payments (s 23);

- all agreements made to be valid in law (s 24);

- consent of the occupier not valid without written authority of the owner etc (s 25);

- actions may be brought at Westminster (s 26);

- no person prevented from inclosing his lands for his own use (s 27); ${ }^{82}$

- $\quad$ saving in respect of all rights of his Majesty, lords or manors etc. (s 28)

As it is, this Act was little used ${ }^{83}$ and it was superceded in practice ${ }^{84}$ by the Inclosure Act 1845 which provided for the appointment of Inclosure Commissioners, who were independent and more efficacious. Hunter (writing in 1902, nearly 120 years ago) summed up the demise of the 1773 Act:

It is unlikely, that any inclosure under this statute would be practicable, or would be attempted at the present day. ${ }^{85}$

Such an observation would apply even more so today since there are no common (open) fields now being tilled

\footnotetext{
${ }^{77}$ This referred to persons who did not till the common fields but had a right of common pasture appendant by virtue of the pasture land being attached to their house (cottage). See Benson v Chester (1799) 8 TR 396 (101 ER 1453).

${ }^{78}$ This referred to persons with a right of common pasture appurtenant for sheep.

${ }^{79}$ For the meaning of 'balk' see text to $\mathrm{n} 19$.

80 'Stinted' meant that there was a limit on the number - and kind - of cattle (e.g. milch cows, draught cattle and other animals which required better food during the summer). See Nasse, n 13, p 10. Ubhi, n 11, p 27 'Stinted pastures have various names, such as cattlegate, beastgate (Suffolk), cowgrasses, beastgrasses, cow-leaze (Epping Forest), and pasturegate.' Gated' and 'stinted' mean the same thing, the terms denoted the number of animals that the holder of the right is entitled to put on the common. Cattlegate is probably the most common term to describe these various rights...'

${ }^{81}$ Section 19, 'provided nevertheless, that a portion of such common pastures shall be separated and set apart for the use of such commoners exclusively as shall not consent to such regulation, and the portion so set apart shall be adjudged by a majority of such commoners not consenting as aforesaid [as] an equivalent for their rights of common.'

${ }^{82}$ Section 27, 'Provided that nothing in this Act contained shall prevent or extend to prevent any person or persons from inclosing all or any part or parts of his, her or their land to and for his, her or their own use or benefit, such person or persons having full power or right so to do.'

${ }^{83}$ Scrutton, n 10, p 154.

${ }^{84}$ Elton (in 1868), n 10, p 155 (operation of the 1773 Act 'now superceded' by the 1845 Act).

${ }^{85}$ Hunter, n 10, p 234. See also Harris, n 11, p 24.
} 
(save for Laxton, see 5(a)). The Inclosure and Drainage (Rates) Act 1833 - still extant - may also be noted. It provides a mode of proceeding (distress) for the recovery of poor rates (or assessments) under the Inclosure Acts where no remedy had otherwise been given. ${ }^{86}$ Poor rates no longer exist. Thus, this Act is, also, spent.

\section{In conclusion, the Inclosure Acts 1773 and 1833 should be repealed, as (manifestly) spent.}

\section{INCLOSURE ACT 1845}

\section{(a) Introduction}

After the 1733, further general legislation on inclosures was passed. Woolrych (writing in 1850) summarised the position:

as well before as after this statute [i.e. the $1773 \mathrm{Act}$ ], many [local] acts passed for the inclosing particular wastes, till at length they became of such frequent occurrence, and their utility so apparent, that it was determined, for the purpose of reducing the expense of carrying them through Parliament, to consolidate the principal clauses which it had been found necessary to insert in the respective local acts into one statute.

This was done by 41 Geo 3, c 109 [Inclosure (Consolidation) Act 1801, repealed by the Commons Act 1899]. This statute made very extensive provisions for the general enclosure of wastes. It became, as it were, an index to local acts, and supplied any omissions for which the local statute had failed to make arrangement. And, although local acts were very generally adopted, an inclosure might have been carried out by virtue of the general act alone. But the 41 Geo 3, c 109 [Inclosure (Consolidation) Act 1801], had no efficiency in improving common fields: it dealt with commons the soil of which was parcel of the lord's waste, without affording any facilities towards the inclosure of open and arable lands.

After some difficulty, it consequently happened, that an Act, specially appropriated to the purpose, was passed, under which some inclosures were effected. This was the 6 \& $7 \mathrm{Wm} 4$, c 115 [Inclosure Act 1836, repealed by the Commons Act 1899]. Yet, notwithstanding an occasional doubt upon the subject, it seemed at length to be agreed, that the $54^{\text {th }}$ section of that Act, which forbade the extension of it to any case of [manorial] waste, must be literally construed. And, on the other hand, a more universal measure, and a central authority in matters of inclosure seemed to be required. Hence, in the year 1845, a statute was passed of the enlarged character above alluded to, and it creates virtually, though not positively, a repeal of the former laws... ${ }^{87}$ (wording divided for ease of reference)

Thus, the problem was that there was no general Act dealing with inclosure prior to 1845 . One which sought to set out matters in a consolidated and simple fashion. One also designed to covered the inclosure both of common arable land (open fields) and of common uncultivated land, part of the lord's waste.

\section{(b) Purpose \& Nature of the 1845 Act}

The purpose of the Inclosure Act 1845 (the ' 1845 Act') ${ }^{88}$ which is extant, was to facilitate inclosure as well as the improvement of commons and commons fields etc as indicated in its Preamble (now repealed). ${ }^{89}$ The Act provided for the appointment of three 'Inclosure Commissioners' as well as for various assistant commissioners to whom they could delegate their powers. ${ }^{90}$ The 1845 Act contained over 160 sections, some 64 sections of which are still extant. The Act covers virtually every description of common land. ${ }^{91}$ Thus, section 11(description

\footnotetext{
${ }^{86}$ Woolrych, n 10, p 98 'Every species of property within a parish, having an occupier, and producing a certain profit, ought to contribute to these [poor] rates, and hence, unenclosed lands are liable to such an assessment.' Ibid, ch 12.

${ }^{87}$ Ibid, pp 318-9. See also the Report of the Select Committee on Commons Inclosure together with the Minutes of Evidence, 1844.

${ }^{88} 8$ \& 9 Vict c 118. It did not repeal local and private Acts, but enabled inclosure pursuant to a general Act. Peek, n 10, p 271 'The General Inclosure Act of $1845 \ldots$ was passed to place the whole management of inclosure in the hands of commissioners, and abolish the necessity of a separate Act of Parliament [i.e. a private or a local Act] in each individual case...'. Ibid, pp 342-5. See also RC, n 11, App 2 (Hoskins), p 165 who summarised the nature of the Act (para 54), as did p 176 (Ivor Jennings QC).

89 'Whereas it is expedient to facilitate the inclosure and improvement of commons and other lands now subject to rights of property which obstruct cultivation and the productive employment of labour, and to facilitate such exchanges of lands, and such divisions of lands intermixed or divided into inconvenient parcels, as may be beneficial to the respective owners; and it is also expedient to provide remedies for the defective or incomplete execution and for the non-execution of powers created by general and local acts of inclosure, and to authorise the revival of such powers in certain cases.' See also Woolrych, n 10, pp 319-20.

${ }^{90}$ See 1845 Act, s 10. Also, Woolrych, n 10, pp 321-2. Scrutton, n 10, p 158 'The method of enclosure was an inquiry by the Inclosure Commissioners, who, if they were satisfied of the expediency of the enclosure, drew up a scheme: all schemes for the year were submitted to Parliament in one general Act.' The functions of the inclosure commissioners were, later, passed to the Secretary of State for the Environment.

${ }^{91}$ Ibid, p 322 'The important task of embracing nearly every description of commonable land is now introduced, and we shall find that other lands, not commonable, may be included in the inclosure, as by way of exchange for lands, commonable or not commonable.' See also 1845 Act, ss 93, 147.
} 
of land to be inclosed under this Act) states that: 'All such lands as are herein-after mentioned, (that is to say,)

all lands subject to any rights of common whatsoever, and whether such rights may be exercised or enjoyed at all times, or may be exercised or enjoyed only during limited times, seasons, or periods, or be subject to any suspension or restriction whatsoever in respect of the time of the enjoyment thereof;

all gated and stinted pastures ${ }^{92}$ in which the property of the soil or of some part thereof is in the owners of the cattle gates or other gates or stints, or any of them; and also all gated and stinted pastures in which no part of the property of the soil is in the owners of the cattle gates or other gates or stints, or any of them;

all land held, occupied, or used in common, either at all times or during any time or season, or periodically, and either for all purposes or for any limited purpose, and whether the separate parcels of the several owners of the soil shall or shall not be known by metes or bounds or otherwise distinguishable;

all land in which the property or right of or to the vesture or herbage, [i.e. ownership, or right to, the fruit of the soil or to graze] or any part thereof, during the whole or any part of the year, or the property or right of or to the wood or underwood [i.e. ownership, or right to, timber] growing and to grow thereon, is separated from the property of the soil ${ }^{93}$

and all lot meadows ${ }^{94}$ [meadows, the pasturing of which was determined by lot] and other lands the occupation or enjoyment of the separate lots or parcels of which is subject to interchange among the respective owners in any known course of rotation or otherwise,

shall be land subject to be inclosed under this Act' (wording divided for ease of reference and italics supplied). The nature of the Act was for the Inclosure Commissioners (now the Secretary of State for the Environment) to issue an annual report, which was to be laid before Parliament. The report would specify the applications for inclosure - as well as the Inclosure Commissioners' grounds for agreeing to the same (or grounds for refusal) together with any special grounds in respect of inclosure. ${ }^{95}$ On the basis of such a report, Parliament would enact general legislation to effect the same (which Parliament often did, in the distant past). ${ }^{96}$ Gonner summarised the process:

An application on a particular form has to be made to the [inclosure] commission and signed by the owners of one-third in value of the interests in the land. Unless the project is manifestly objectionable an assistant commissioner is then sent down to inspect the land, to inquire into the accuracy of the statements, and to hold a meeting to hear any objections to the proposals. On his report a provisional order for inclosure would be issued setting out certain conditions as to allotments of land for exercise or recreation for the labouring poor, specifying the proportion due to the lord of the manor and the means to be taken for the protection of public rights, and determining the ownership of minerals. By the first Act active steps could then be taken in certain cases, some, however, requiring parliamentary sanction, but by the fifth amendment Act [i.e. the Inclosure Act 1852] the need of such sanction was applied to all cases. The provisional act or order was then deposited in the parish, and an assistant commissioner sent down to hold a meeting for obtaining assents and dissents. On the assent of two-thirds a special act was obtained...

A valuer was then elected, who had to value, to determine claims, and to lay out allotments, his

\footnotetext{
${ }^{92}$ See also RC, n 11, p 176.

${ }^{93}$ Herbage (vesturum terrae) was the right to graze. See also Coke, n 9, vol 1, p (Co Litt 4b) 'vesture of the land, (that is) the corn, grass, underwood, sweepage and the like'. Also, H Spelman, Glossarium Archaiologicum (1646) (herbagium), p 286. See also Stroud's Judicial Dictionary of Words and Phrases (4 ${ }^{\text {th }}$ ed, 1972), vol 2, p 1230 (herbage). RC, n 11, p 171 'The owner of the soil may... grant the sole vesture, the exclusive right to take the produce of the soil, or the sole pasture, the exclusive right to graze animals on the soil, to another in fee simple or he might make the same grant in copyhold.' Ubhi, n 11, p 48 '(vesture) Vesture includes all the produce of the land excluding timber. It includes corn, grass, underwood and all that can be cut by one scythe. A right of vesture does not include any right to the non-agricultural products that can be dug out of the soil. A right of sole vesture might be exercisable by the owner (or owners) of the sole at limited periods of the limited periods of the year leaving the owner of the soil to take agricultural produce, such as a hay crop outside these periods...(herbage) This is the sole right to take grass by cutting or grazing. The right is less than vesture but more than a right of pasture, which does not include the cutting of grass...(pasture) The sole right in pasture, whether held by a single person (a single stint), or more usually by a number of persons (each holding a stint), permits such persons to take the grass only through the mouths of their cattle..'. See also Halsbury Laws, n 11, vol 13, paras 353-4.

${ }^{94}$ See $\mathrm{n} 18$

${ }^{95}$ Ibid, p 327. See also Peek, n 10, p 70. See also Halsbury Laws, n 11, vol 13, paras 320-3.

${ }^{96}$ For the same, see Woolrych, n 10, pp 328-34.
} 
decisions being subject to the commissioners, and, in the case of claims, to the courts by way of appeal. After this, a meeting was held by the assistant commissioner to hear objections in general to the report, and these being disposed of, the report was embodied in an award signed by the valuer, which, on confirmation by the commissioners, became final. ${ }^{97}$ (wording divided for ease of reference)

This Act, however, excluded certain matters from its ambits. Thus, it (expressly) did not deal with the inclosure relating to the following:

- Land in the New Forest (s 13); 98

- Land in the Forest of Dean (s 13); ${ }^{99}$

- Lands within 15 miles of London or 2 miles of any city or town containing 10,000 inhabitants (2 and $1 / 2$ miles if 20,000 ; or 3 miles if 30,000 or 3 and $1 / 2$ miles if 70,000 ; or 4 miles if 100,000$)(s 14)$;

- The inclosure of town or village greens (s 15). ${ }^{100}$

The 1845 Act was also subject to qualified exceptions, including the following:

- where the lord of the manor dissented from the proposed inclosure of his waste (s 29, repealed in 1998); ${ }^{101}$

- unless two thirds of those interested in the land to be inclosed give consent, no inclosure could be made (s 27, repealed by the Commons Act 1876). ${ }^{102}$

Scrutton noted that, between 1845-67, schemes for nearly 900 enclosures under the 1845 Act were framed by the Inclosure Commissioners and sanctioned by Parliament, pursuant to a general Act. ${ }^{103}$

\section{(c) Amendments and Supplements to the 1845 Act}

The 1845 Act was amended by the following Acts, certain sections of which are still extant:

- Inclosure Act $1846 ;{ }^{104}$

- Inclosure Act $1847 ;^{105}$

- Inclosure Act $1848 ;^{106}$

- Inclosure Act $1849 ;^{107}$

- Inclosure Act 1852; $;^{108}$

${ }^{97}$ Gonner, n 12, pp 91-2. See also Ubhi, n 11, pp 104-6.

${ }^{98}$ See also Eversley, n 12, ch 13 and Hunter (in 1902), n 10, ch 17.

${ }^{99}$ Ibid, ch 14 and Hunter (in 1902), n 10, ch 17.

${ }^{100}$ Woolrych, n 10, p 334 'These are to be allotted to the churchwardens and overseers of the parish for the purposes of exercise and recreation, and to be subject to the provisions concerning such allotments. The green may either be in addition to, or in lieu of other land allotted under the $73^{\text {rd }}$ section [allotments for places of exercise and recreation, for the labouring poor etc] for the above purposes. And the commissioners are to set out a boundary between such green and the neighbouring land, unless there be one already fixed, and such boundary is to be mentioned in their general annual report.' See also Scrutton, n 10, pp 158-9; Eversley, n 12, ch 22; Hunter, n 10, ch 18 and Baker, n 10, pp 7-10.

${ }^{101}$ Ibid, p 334-5 'one arises out of the dissent of the lord of the manor from the proposed inclosure of his waste. Whether the land be waste of the manor, or land within any manor, to the soil of which the lord is entitled in right of his manor [i.e. common fields], the inclosure cannot proceed, nor can the commissioners certify concerning it in their annual report in the absence of the concurrence of such lord.'

102 Ibid, p 336.

${ }^{103}$ Scrutton, n 10, p 160. See also Hunter, n 10 (618,000 acres enclosed under 1845 Act until 1869).

${ }^{104}$ See s 6 (assistant commissioner framing draft award), s 8 (when land held by lease for years - or for life - is intermixed with other land), s 10 (steward may consent in writing on behalf of the lord of the manor), s 11 (shares of land and cattle gates and stints may be exchanged), s 12 (maps may be certified by commissioners). See also Woolrych, $\mathrm{n} 10$, pp 341-2.

${ }^{105}$ See s 1 (where the title to a manor etc is litigated the consent of both claimants to be equivalent to the consent of the actual owner), $\mathrm{s} 2$ (consent etc where more than one person is interested in a claim), s 7 (adjournment of meetings), s 8 (notices). See also Woolrych, n 10, pp 335-6.

${ }^{106}$ See s 4 (private and occupation roads), s 6 (appointment of rating officer), s 7 (rating officer to maintain roads etc), s 12 (on neglect of owner of an allotment to fence, owner of neighbouring allotment may do the necessary works).

${ }^{107}$ See s 7 (exchange and partition of rights); s 11 (lands held under separate titles by the same person may be exchanged). See also Woolrych, n 10, p 343-4.

${ }^{108}$ See s 1 (no lands to be enclosed without the previous authority of Parliament in each particular case); s 14 (commissioners may direct that town and village greens and allotments for exercise and recreation shall not be fenced); s 17 (deposit of orders of division, exchange and partition in certain cases); s 21 (allotments set out under local Acts may be exchanged); s 22 (application of compensation for common rights 
- Inclosure Act $1854 ;{ }^{109}$

- Inclosure Act $1857 ;^{110}$

- Inclosure Act 1859; ${ }^{111}$

- Inclosure etc Expenses Act 1868. ${ }^{12}$

It may be noted, in particular, that the Inclosure Act 1852 expressly prohibited the inclosure of land under the 1845 Act without the prior authority of Parliament (this was only necessary under the 1845 Act in the case of certain lands expressly mentioned). ${ }^{113}$ In conclusion:

- The 1845 Act (as amended, which is still extant in part) was a more objective and scientific means of enclosing land and determining the boundaries of the same than the 1773 Act (see 2(i)). It also provided that the award of the commissioners was (generally) conclusive;

- However, the 1845 Act was, relatively speaking, cumbersome, time consuming and expensive. Thus, it is (very) likely that lords of the manor in the period 1773-1845 (and thereafter) acted - not pursuant to these Acts but by way of: (a) approvement under the Statute of Merton 1235 (rep) and the Statute of Westminster 1285 (rep); or (b) approvement under the common law, a process no longer possible since 2006; or (c) agreement between the lord of the manor and commoners. ${ }^{114}$ In the case of the latter, in particular, lords of the manor, generally, bought out (bought up) the commoner's interest in the land or made an exchange of land pursuant to a contractual agreement.

In conclusion, the 1845 Act superceded that of 1773. However, although still extant, it was superceded by the Commons Act 1876 (see below) which adopted a different policy respecting inclosure.

\section{SCRUTTON ON THE INCLOSURE ACTS}

Scrutton wrote his text on Commons and Common Fields in 1887. He made little reference to the 1773 Act and he concentrated on the 1845 Act. Scrutton also noted that - in his time - commons (i.e. common fields and manorial waste) might be inclosed in one of 4 ways viz.

- $\quad$ by the Inclosure Commissioners, with the sanction of Parliament; ${ }^{115}$

- $\quad$ pursuant to the Statutes of Merton 1235 and Westminster 1285 (now repealed); ${ }^{116}$

paid under the Lands Clauses Consolidation Act 1845), s 29 (correction of awards), s 33 (penalty where stock is found on regulated pastures contrary to the regulations), s 34 (short title).

${ }^{109} \mathrm{~S} 3$ (definition of land); s 4 (lessee to be deemed the person interested in certain cases); s 5 (application for exchange, partition or division by parties in possession under agreements for exchange etc); s 8 (land to include rights); s 9 (fencing of roads, or making them of hard materials, may in certain cases be dispensed with); s 10 (application for apportionment of fee farm rents); s 11 (order of appointment); 12 (lands to be charged only as directed by such order); s 13 (recovery of apportioned amounts); s 14 (expenses attending apportionment); s 15 (where a committee to whom compensation is paid cannot apportion, a meeting of persons interested may be called); $\mathrm{s} 16$ (if the meeting determines for apportionment, money to be paid into the Bank of England); s 17 (value of the respective shares of the parties interested to be ascertained according to the value of their interests in the common lands); s 18 (costs of commissioners to be paid out of the money paid in); 19 (in the case of limited interests, the shares, if exceeding $£ 20$, to be paid to trustees); 20 (payment of shares not exceeding $£ 20$ ); $\mathrm{s} 21$ (construction).

${ }^{110} \mathrm{~s} 1$ (fences may be dispensed with); s 2 (allotments, until fenced, to be deemed a regulated pasture); s 3 (notices and claims); s 10 (rentcharges); s 11 (rentcharge to go with the land the deficiency in value whereof it compensates); s 12 (protecting from nuisances town and village greens and allotments for exercise and recreation).

${ }^{111}$ See s 3 (power to work mines); s 4 (how damage to be assessed); s 5 (payment of damages); s 6 (to be levied by distress); s 7 (annual value of allotments to be stated in the award); 12 (where patronage to be vested in the Crown, who is to be deemed patron).

${ }^{112}$ See $\mathrm{s} 1$ (security for costs on inquiries to be taken by the commissioners).

${ }^{113}$ Peek, n 10, p 346. The Act, s 1, provided that 'Notwithstanding the provisions in the Inclosure Act 1845, it shall not be lawful for the Inclosure Commissioners...to give notice of their intention to proceed with the inclosure of any lands without the previous direction of Parliament; and no land shall be inclosed under the said recited Acts and this Act without the previous authority of Parliament in each particular case...'.

114 See also Commons Act 1976, s 31 (if all rights vested solely in the lord of the manor) and Hunter, n 10 , p 21.

115 Scrutton, n 10, p 162 'The Parliamentary method of enclosure, under the statutes just referred to, applies to all land over which any common rights exist, unless such land is in the metropolitan area or within a certain distance of towns of a certain number of inhabitants, or is a village green, in which case the Commissioners cannot deal with it. They are directed to investigate the way in which the proposed enclosure may affect both public and private interests, and to report fully to Parliament, which then has the opportunity of confirming, rejecting or varying the proposed scheme of enclosure.' See also Peek, n 10, p 347

${ }^{116}$ Ibid, p 169 'This method...only applies to lands where the only rights of common existing are commons of pasture, and where the lord leaves sufficiency of pasture for the commoners....In Lascelles $v$ Lord Onslow (1877) LR 2 QBD 433, the court expressed the opinion that, if the lord could prove that he had left sufficiency of pasture for all the cattle that had usually been put on the waste within the last 10 years, it was enough.' See also Peek, n 10, p 348. 
- with the consent of the commoners; ${ }^{117}$

- without any justification in law (i.e. unilaterally, such as by squatting).

When Scrutton wrote (in 1887) there were few common fields in existence. The burning issue, then, was not the inclosure of common arable fields but of common (non arable) land (i.e. manorial waste) that was used by the general public - for walking or as an (unauthorized) allotment or in respect of which the commoners had some right of common. ${ }^{118}$ In particular, there was a growing movement for the protection of 'open spaces'- something which was to become a major 'cause' in the $20^{\text {th }}$ century. As for the overall efficacy of the 1845 Act, Scrutton stated:

The object of the Act was both to facilitate enclosures, and by bringing them under the supervision of judicial commissioners to protect the interests of the poor; while the provisions as to lands near large towns were designed to prevent the absorption of open spaces which might provide breathing spaces and play-grounds for their inhabitants.

The Act was however insufficient to attain its purpose completely, so far as that purpose was to protect the interests of the community. The right of the lord of the manor to enclose the wastes of his manor under the Statute of Merton [1235] provided he left sufficiency of pasture for the persons entitled to common, still remained.

The gradual disuse of manorial courts removed a simple machinery for checking encroachments on the wastes; the lords [of the manor] acquired one by one the interests of freeholders and copyholders by purchase or otherwise; and changed ideas as to agriculture had the result that few but the very poor used their common rights at all. These commoners could not enter into a difficult and expensive contest with the lord of the manor, and so, either rightfully or wrongfully, the lord enclosed, buying up some rights, silencing other claimants with grants of part of the enclosed land, ignoring the poor. ${ }^{119}$ (wording divided for ease of reference).

In conclusion, the 1845 Act was more flexible than the 1773 Act (and only required two thirds of the consent of the commoners as opposed to three-quarters under the 1773 Act). However, it was still time consuming and costly (albeit, less so than proceeding by way of local or private legislation). It was to be replaced by the Metropolitan Commons Act 1866 (which dealt with commons in the London area) and the Commons Act 1876 (see 5) both of which adopted a different policy towards the inclosure of common land.

\section{REPEALING THE INCLOSURE ACTS 1733 - 1868}

Just as the 1773 Act was superceded by the 1845 Act and should be repealed since there is no reason for its continued retention including the absence of any common fields (save for Laxton, see below), the 1845 Act (as amended) belongs to a by-gone era and it should be repealed, it is asserted, for the following (simple) reasons:

\section{(a) 1845 Act - No Common Fields}

The primary purpose of the 1845 Act was to deal with common arable fields. However, there are, now, no common arable fields being tilled today (with one exception, Laxton) - this means of land usage not being profitable after the $1^{\text {st }}$ World War, if not before. Further, the last inclosure of arable (open field) land under the Inclosure Acts appears to have been in 1914 (or even 1901), ${ }^{120}$ more than 100 years ago.

- Laxton Manor. Thus, not only is all the material in the 1845 Act historic (with most of the issues arising out of any award having been decided long ago) there is no possible future application of the 1845 Act (or that of 1773) so far as it relates to common arable land, apart from the manor of Laxton in Nottinghamshire;

\footnotetext{
${ }^{117}$ Ibid, p 168 'The third method is by the consent of the commoners, either individually obtained, or given the custom of the manor through their representatives in the manor court.' Elton, n 10, p 166 'commons may be extinguished by mutual agreement between the commons and the owner of the waste, the rights of the former persons being thus abandoned by themselves.' See also Jessel, n 12, p 131. Also, Jessel Twenty First, $\mathrm{n} 12, \mathrm{p} 37$ 'It has always been possible for owners of common land to take a release of common rights and so to extinguish them. This has been done for centuries and was a method of inclosing common land without the need for an Inclosure Act. It could only work where there were just a few commoners and they were prepared to co-operate. Owners of common land have been reluctant to buy up rights piecemeal and one by one because the price they had to pay to a commoner to extinguish his rights would not be reflected in the increase of value to the owner.'

${ }^{118}$ The same time Scrutton was writing, the Allotments Act 1887 was being passed. Scrutton, n 10, p 176.

${ }^{119}$ Scrutton, n 10, p 160.

${ }^{120}$ See $n 132$ (text)
} 
- Inclosure of Laxton Manor. This manor is deliberately maintained as an open (common) field system by the Crown Estate (as lord of the manor, who bought it in 1981). ${ }^{121}$ The open fields comprise three large fields (formerly, there were four) which appear to be presently farmed by c. 14 commoners. ${ }^{122}$ The Crown Estate is seeking to sell the manor. ${ }^{123}$ Therefore, these fields may become inclosed. However, such would not be done (it is asserted) by virtue of any Inclosure legislation (general, local or private). This would be too cumbrous and expensive and there is no need for Inclosure Commissioners (now the Secretary of State for the Environment) since the ambits of this common land are well known and the number of commoners few. Instead - excepting a covenant ${ }^{124}$ - inclosure could be effected by: (i) consent (including any buyout or exchange); ${ }^{125}$ or (ii) pursuant to later Acts which were designed to supercede the 1845 Act (see (b) below).

\section{In conclusion, the primary purpose of the Inclosure Acts 1733-1868 - to inclose common arable land (i.e. open field land) - has gone, none being left.}

\section{(b) Commons Act 1876 superceding the 1845 Act}

In 1865 , there arose public concern about the inclosure of common land (especially in London) and the public attitude (as well as that of Parliament) hardened against it - the concern being that inadequate provision was being made by lords of the manor for open spaces (parks etc) and allotments on their manorial waste. In the case of London (to which the 1845 Act did not apply), this led to the Metropolitan Commons Act 1866, which is still extant and, from this Act, there was a movement to obtain more 'balanced' general legislation in respect of commons - whether common fields or the lord's waste. In particular, the Metropolitan Commons Act 1866 prohibited metropolitan commons (and town and village greens) from being inclosed. ${ }^{126}$ However, this Act of 1866 only related to London. Hunter (writing in 1902) while noting that the purpose of the 1845 Act had been to diminish the cost of inclosure and to further facilitate it, observed:

the process [of inclosure under the 1845 Act] continued unchecked till 1869, when inclosure was arrested at the instance of the late Mr Fawcett, ${ }^{127}$ on the ground that it was in the interests of the country to preserve open lands for health and recreation, rather than to inclose them with the object of increasing the food supplies of the country. This view was completely endorsed by the Conservative government of the day, when, in 1876, the Commons Act of that year was passed into law.

This Act, without repealing the Act of $1845^{128}$ and the various Inclosure Acts, laid down new

\footnotetext{
${ }^{121}$ See GS McBain, Abolishing various Obsolete Courts (2012) Coventry LJ, vol 17, no 1, p 30. Manor courts are now extinct, Ibid, pp 26-7.

${ }^{122}$ The three open fields comprise the West, Mill and South fields. They operate on a three year rotation, being left fallow in the third year, similar to the Anglo-Saxon, and early medieval, three field system. These fields are by tenants in common socage (i.e. freeholders; cf. copyholders). Such can agree to inclose these fields (ie. to extinguish their common rights, subject to any right of common of the lord of the manor). See RC, n 11, p 168 (para 9) and n 125. See generally, JV Beckett, A History of Laxton (1989) and CS \& CS Orwin, The Open Fields (1938). The latter work contains an excellent description of Laxton manor in pt 2 of the same. The court leet (combined with the court baron, pp 81, 125-7, 173) still sits. The descent of Laxton manor (held by knightservice) can be traced from the Norman Conquest (pp 72-3, 79). Exchanges of land by consent were common (p 77 (charter of 1232), pp $162 \& 165$ ) obviate the need for an Inclosure Act. Tenure by villeinage appears to have ended by 1635 ( $\mathrm{p} 107)$

${ }^{123}$ The estate (which was offered for sale in October 2018) comprises (it is said) 1845 acres with 17 working farms, 10 cottages and a court leet (said to be the only one left, with power to impose token fines from $2 p-£ 20$ ).

${ }^{124}$ When the Crown Estate acquired the manor in 1981 they gave an undertaking to maintain the open field system (they acquired it from the Ministry of Agriculture who acquired it from Earl Manvers (lord of the manor) in 1952). There was also a Countryside Stewardship Agreement between the court leet and the (then) Countryside Commission.

${ }^{125}$ Approvement at common law is no longer possible today, see Commons Act 2006, s 47(2). Also, RC, n 11, p 92. Inclosure by consent of the lord and the commoners was well established. Yelling, n 12, p 17 'In the two centuries before 1760 general enclosure by agreement was the normal form of enclosure in certain districts'. Yelling quoted, p 8, HS Homer, An Essay on the nature and method of ascertaining the specific shares of proprietors upon the inclosure of Common Fields (1766), p 42 'An inclosure of common fields is either brought about by general consent of the proprietors interested therein, in which case a deed of mutual agreement, confirmed by the Court of Chancery is sufficient to establish the exchange of property...'. Also Yelling, p 22, quoted A Fitzherbert, The Boke of Surveyinge and Improvements (1539), p 58 'a man might make every township that stands in the plain champaign [rural] county and occupied in tillage half as good again in all manner of profits to the tenants as it was before, if the lords thereof and their tenants can agree of the costs [i.e. agree to inclosure].' (spelling modernised). See also Gonner, n 12, pp 51-2; RC, n 11, (Ivor Jennings QC), p 172 and Ubhi, n 11, p 57.

${ }^{126}$ See also RC, n 11, (Ivor Jennings QC), pp 178, 181. See also Metropolitan Commons Act 1866, ss 4 \& 5.

127 On Henry Fawcett MP, see Eversley, n 12, ch 16 (which discusses the Commons Act 1876) See also, L Stephen, Life of Henry Fawcett (1885).

${ }^{128}$ In hindsight, the Inclosure Acts should have been repealed and matters consolidated in the Commons Act 1976 (which should have also covered the Metropolitan Commons Act 1866). However, at the time, there were also landowning concerns for the Government to accommodate and, so, this would not have been feasible.
} 
principles to guide the Inclosure Commission in dealing with proposals for inclosure, provided an alternative method of dealing with commons - that of their regulation as open spaces - and introduced many alterations of procedure in the interests of the public...'. ${ }^{129}$ (italics supplied and wording divided for ease of reference)

Hunter also noted:

The Commons Act 1876, does not prohibit inclosure at the instance of the Inclosure Commission...but it declares 'that it is desirable that inclosure in severalty [i.e. to make the land private land] as opposed to regulation of commons should not be hereafter made, unless it can be proved to the satisfaction of the Commissioners and of Parliament that such inclosure will be of benefit to the neighbourhood as well as to private interests, and to those who are legally interested in any such commons.",130

Thus, today, any inclosure would (indeed, should) be under this and subsequent Acts and not the prior inclosure Acts since the Commons Act 1876 and later Acts reflect the more recent will of Parliament. That is, the emphasis is more on regulating commons as opposed to inclosing them. Eversley, writing in 1910, noted the effect of the Commons Act 1876:

an entirely new policy with respect to inclosures was imposed upon the Inclosure commissioners... in the thirty-four years which have elapsed since the Commons Act of 1876 became law, twenty-eight commons only have been inclosed.... ${ }^{131}$ Since 1886 there have been only five cases of inclosure, and these have been mainly confined to the partition of common [open] fields. No inclosure schemes have been approved since $1901 \ldots$

The Commons Act, 1876, had not for its only object the protection of commons from inclosure under the provisions of the General Inclosure Acts [1733-1868], where the public was opposed to such a course. Lord Cross, the author of the measure [i.e. the Commons Act 1876] laid great stress upon the alternative process provided by it of permanently preserving them as open spaces, and protecting them from nuisances, by placing them under the management of local boards of conservators, by means of schemes of regulation. ${ }^{132}$ (italics supplied)

For its part, the Royal Commission of Common Land in 1958 (Ivor Jennings QC, Chairman) noted that 'there had been a change of emphasis between 1845 and 1867' and that the last case of inclosure (this under the Commons Act 1876, see below) and not under the Inclosure Acts 1773-1868, was in $1914{ }^{133}$ Thus, the latter Acts have been redundant, at least, from 1914 and (probably) since 1901. ${ }^{134}$ Also, even under the Commons Act 1876, the process of inclosure has been redundant since 1914. As for the regulation (cf. inclosure) of commons, this is now governed by the Commons Act 1876 and the Commons Act 1899 - which Acts are now considered.

\section{(c) Nature of the Commons Acts 1876 \& 1899}

The Commons Act 1876 requires that any common regulated thereunder cannot be inclosed without the sanction

\footnotetext{
${ }^{129}$ Hunter, n 10, p 135. See also O Hill, Our Common Land (and other Short Essays)(1877), p 180.

${ }^{130}$ Ibid, p 280. Ibid, pp 15-8. See also Eversley, n 12, pp 193-4.

131 The RC, n 11, p 29 (writing in 1958) noted 'The Metropolitan Commons Act, 1866, and the subsequent amending acts...made inclosure in the Metropolitan area practically impossible. Ten years later Parliament passed the Commons Act, 1876. It was this Act which came to be regarded as greatly reinforcing the legal protection of common land...Since 1876, only twenty-eight applications under the Act...have been approved...none has been approved since 1914. Common land was thus kept open [i.e. kept as common land] by legislation in the second half of the nineteenth century and saved from inclosure.' See also Ibid, p 55. Also, p 165-6 (Hoskyns) 'The [Commons Act 1876] discouraged inclosure by making it difficult and costly, and encouraged regulation.' (italics supplied). Also, Ibid, p 177 (Ivor Jennings QC) (only 29 applications for inclosure under the 1876 Act, the last in 1914, only 36 applications for regulation, the last in 1919)(italics supplied). Jessel, $\mathrm{n}$ 12, p 138 'After 1876 there were only 29 applications for inclosure, the last being in 1914, and section 194 of the Law of Property Act 1925 in effect prevented any more.' He quoted Hampshire CC v Milburn [1991] 1 AC 325, 339.

${ }^{132}$ Eversley, n 12, pp 198-9. Ubhi, n 11, p 107 (in 2006) 'Although the provisions relating to inclosure in the Inclosure Act 1845 and the Commons Act 1876 are still on the statute book, these powers have not been used for some considerable time, and must be regarded in the present political climate as being virtually obsolete.'

${ }^{133} \mathrm{RC}, \mathrm{n} 11, \mathrm{p} 177$ 'In effect....inclosure has since 1876 been provided for by the [Commons Act 1876], which incorporates the Inclosure Acts, 1845 to 1868 , as amended. There have, however, been only 29 applications for inclosure since 1876, the last case being in 1914. Nor indeed has the Act been used much more freely for regulation. There have been 36 applications, the last case being in 1919.' (italics supplied). Halsbury Laws, n 11, vol 13, para 319 refers to 1914 ('Only 29 applications for inclosure were made under the Inclosure Act 1845 after 1876, the last being in 1914.', italics supplied ) However, care needs to be taken with this date of 1914 since this refers to applications not to actual inclosure pursuant to an award the last of which may have been in 1901, see n 134 below. Further, Halsbury Laws refers to the Inclosure Act 1845 when the reference should be to the Commons Act 1876.

${ }^{134}$ See the text to n 132 where Eversley refers to 1901.
} 
of Parliament. ${ }^{135}$ As for regulation, no provisional order had been made under Commons Act 1876 since 1919, due to the need for Parliament to confirm any provisional order. ${ }^{136}$ The Act, thus, used for regulation is the Commons Act 1899 which enables local councils to regulate commons, including the making of bye-laws. ${ }^{137}$ This Act was more availed of than that of 1876 since it did not have some of the restrictions of the same. ${ }^{138}$ Thus, vis-a-vis both inclosure and regulation all of the Inclosure Acts 1773-1868 and the Common Act 1876 are obsolete as Halsbury Laws notes (although it did not mention the Inclosure Act 1773):

The Inclosure Acts 1845 to 1882, and in particular the Commons Act 1876, contained provisions for applications to be made for the regulation of commons. These provisions are still material in so far as existing schemes, but the procedure for regulation may be regarded as obsolete. ${ }^{139}$

As for the Commons Act 1899, Clayden (writing in 1985) summarised it thus:

This Act is intended to provide a simple and inexpensive means of enabling districts councils to manage and improve commons where their use for exercise and recreation is the prime consideration, and where the owner and commoners do not require a direct voice in the[ir] management (as they have under the 1876 Act schemes). The Act also applies to village greens...

Schemes do not require the consent of the Secretary of State or of Parliament. Nothing in the scheme may take away or adversely affect the rights of the owner or the commoners without compensation being paid. Either the owner or persons representing one third in value of the interests of the commoners may veto the scheme. The council must advertise its intention to make a scheme and allow at least three months for objections or representations. ${ }^{140}$ (italics supplied and wording divided for ease of reference)

It may also be noted that the inclosure commissioners (the inclosure commission) under the Inclosure Acts 1733-1845 also had a name change, becoming the land commission in 1887. The land commission, later, merged into the Board of Agriculture, who took over its role of regulating commons under the Commons Acts 1876-1893. ${ }^{141}$ Today, this role is performed by the Secretary of State for the Environment. The following may be observed by way of postscript:

\footnotetext{
${ }^{135}$ Commons Act 1876, s 36 (a common regulated under Act not to be inclosed without sanction of Parliament) 'Where an Act of Parliament has been passed confirming a provisional order under this Act for the regulation of a common, then, subject to and without prejudice to the provisions of that order, such common shall not, nor shall any part thereof, be inclosed without the sanction of Parliament subsequently obtained.' See also Hunter, n 10, p 294.

${ }^{136}$ Clayden (1985), n 11, p 42 'The need for Parliament to confirm the relevant order and the difficulty sometimes experienced in satisfying the rights of the parties has led to the 1876 provisions falling into disuse. The last Provisional Order Confirmation Act was passed in 1919 [see $n$ 131] and related to Coity Wallia Commons in S Wales. Amendments thereto were made in 1976, but a private Act was secured rather than a Confirmation Act under the 1876 Act procedure.'

${ }^{137}$ Commons Act 1899, s 1(1)(power for district council to make scheme for regulation of common). (1) The council of a district may make a scheme for the regulation and management of any common within their district with a view to the expenditure of money on the drainage, levelling, and improvement of the common, and to the making of bylaws and regulations for the prevention of nuisances and the preservation of order on the common. (2) The scheme may contain any of the statutory provisions for the benefit of the neighbourhood mentioned in [the Commons Act 1876, s 7]. (3) The scheme shall be in the prescribed form, and shall identify by reference to a plan the common to be thereby regulated, and for this purpose an ordinance survey map shall, if possible, be used. (4) Regulations under subsection (3) may - (a) prescribe alternative forms; (b) permit exceptions or modifications to be made to any prescribed form. See also Hunter, n 10, ch 25.

${ }^{138}$ Eversley, n 12, p 259 (writing in 1910) 'This Act [of 1899]...differs from the Commons Act of 1876, as regards regulation schemes, in that it enables the local sanitary authority of any district, in which a common exists, to make application to the Board of Agriculture, without the previous assent of the lord of the manor, and of one-third in value of the commoners. On the other hand, it has greatly simplified and lessened the cost of proceedings before the Board of Agriculture in the framing of schemes, as it does not require that schemes shall be laid before Parliament for confirmation by an Act, and does not therefore entail the possible expense of a Parliamentary inquiry. The effect of these relaxations has been that far more numerous applications have been made under this Act.'

${ }^{139}$ Halsbury Laws, n 11, vol 13, para 488.

${ }^{140}$ Clayden, $\mathrm{n} 11, \mathrm{p} 43$. He noted (in 1985) there were some 200 commons regulated under the 1899 Act. Objection by the owner was rare, see $\mathrm{RC}$ (writing in 1958), n 11, p 73'The draft of a scheme of inclosure, or, more important in this connection, of regulation, under the Commons Act, 1876, may not proceed without the consent of the owner of the soil; nor, if the owner objects, may a scheme of regulation under the Commons Act, 1899. All the other parties concerned, the local authorities, inhabitants, and commoners, may be unanimous about the necessity for a scheme, but the veto of the owner of the soil is absolute. In fact, it appears that he has seldom chosen to exercise it. Of [327] applications received by the Ministry of Agriculture for schemes under the 1899 Act, only [12] have been withdrawn because of objections by the owner and in [3] cases schemes were made subsequently. Since 1939, only one scheme among [68] has been objected to.' The RC (in 1958) recommended the owner's veto in the Commons Act 1899 be removed. For the present law, see Halsbury Laws, n 11, vol 13, para 492.

${ }^{141}$ Eversley, n 12, p 202 noted 'In administering the Commons Acts of 1876 and 1899, and the Law of Commons Amendment Act of 1893 and other Acts relating to the inclosure and regulation of commons, the Board of Agriculture has not inherited the bad traditions of the old Inclosure Commission, whose work it has taken over.'
} 
- After the Commons Act 1899, commons were also regulated pursuant to: (a) the Law of Property Act 1925 (s 193); ${ }^{142}$ (b) local Commons Acts; (c) National Trust Acts; ${ }^{143}$ (d) access agreements under the National Parks and Access to the Countryside Act 1949; (e) by local authorities under the Open Spaces Act 1906 and under the Countryside Act 1968; ${ }^{144}$

- In 2015, the Open Spaces Society calculated that common land comprised less than 4\% of the land in England in Wales with nearly all of it now being mapped. ${ }^{145}$

In conclusion, the Commons Act 1876 was designed to supercede the 1845 Act (as amended) - especially in terms of the underlying purpose as to the future use of commons. That is, regulation of the same (as opposed to inclosure by the lord of the manor with such, thereby, excluding commoners from using the commons).

(d) 1845 Act - No Lords of the Manor

Both the Inclosure Acts 1733-1845 and the Commons Act 1876 were predicated on there being 'lords of the manor'. As it is, even if there were many lords of the manor existing 150 years ago, do any exist today ? In respect of this:

- $\quad$ No New Manors post-1290. New manors could not be created after the Statute of Quia Emptores 1290 (see 8) because of its prohibition on the subinfeudation of the fee simple. ${ }^{146}$ Further, to continue to exist, a manor requires a court baron, which court requires a minimum of two freeholders subject to escheat. $^{147}$ In 1859 , there were said to be only 5 courts baron in existence. ${ }^{148}$ Today, there appear to be none; ${ }^{149}$

- $\quad$ Few Lords of the Manor. Thus, today, there are (actually) very few manors still existing with lords of the manor having legally enforceable rights. Indeed, the 'lord of the manor', today, is likely to be no more than a person who holds the fee simple of former copyhold land ${ }^{150}$ (copyhold having been abolished in 1925) with certain rights thereover.

In short, most 'manors'(if not all), today, are no more than 'reputed' (i.e. alleged) manors with the existence of their legal rights not having been challenged in court. ${ }^{151}$ Thus, the tenor of the Inclosure Acts 1773-1868 no longer applies since these Acts envisage a legitimate - and not a quasi - 'lord of the manor'.

In conclusion, the Inclosure Acts 1773-1868 should be repealed. There is no common arable land for them to apply to (excepting Laxton). Also, the 1845 Act (the primary Act) does not apply to urban areas, the Forest of Dean, the New Forest or to village greens. Finally, the Commons Act 1876 has superceded these Inclosure Acts (as intended) and it - and later legislation - reflects a more balanced approach to the rights of commoners as well as to those of the lord of the manor. The general principle is that of regulation - not inclosure (i.e. extinction of commonality, including rights of common).

\footnotetext{
${ }^{142}$ See section 193 (rights of the public over commons and waste lands). For discussion on this section see RC, n 11, pp 30-1, 181-2.

${ }^{143}$ See National Trust Act 1907 (rep) and the National Trust Act 1971 (rep).

${ }^{144}$ Clayden summarised these in 1985, see n 11, pp 43-8. See, for today, Halsbury Laws, n 11, vol 13, para 325.

${ }^{145}$ G Bathe, Common Land (2015), p 3. See also Ubhi, n 11, p 4.

${ }^{146}$ Peek, $\mathrm{n} 10, \mathrm{p} 352$ 'after the passing of this statute, it was impossible for any one to create a manor, and it was even impossible for any lord of any existing manor to create any one new tenure.' See also Hunter, n 10, p 40.

${ }^{147}$ Ibid, p 353 citing Glover v Lane (1789) 3 TR 447 per Lord Kenyon. Ibid, p 353 'To constitute a manor it is necessary not only that there should be two freeholders within the manor, but two freeholders holding of the manor, subject to escheats...' Peek continued 'But in order to prove his claim to two such freeholders, the lord [of the manor] must show that their ancestors or predecessors in title were tenants of the manor at a date anterior to [1290]...The difficulty of tracing an unbroken title through so long a period is evidently sufficient to make the cases in which such freeholders can be claimed by a manor extremely rare...'(italics supplied).

${ }^{148}$ Peek, n 10, p 322 'It appeared by the Judicial Statistics of 1859, that five courts-baron and five hundred-courts still preserved at that time some signs of vitality.'

${ }^{149}$ Courts baron (and court hundreds) no longer operate post-1977, see McBain, n 121.

${ }^{150}$ Peek, n 10, p 353 (writing in 1867) 'It may therefore be a grave question, whether there are more than five manors really existing in England. Those who claim to be lords of manor are in reality for the most part not such. They are merely persons who have seignory over certain copyhold lands and over certain waste lands. Their seignory over their copyholders is easily proved, for the incidents of the estate are so numerous and favourable to the lord that they have never been allowed to lapse, and the holding is distinctly traced through all times which can be remembered. A copyholder must hold of some lord of the manor, in whom the fee simple of the estate is vested and at whose will merely he is tenant. The fee simple of a freeholder's estate, on the contrary, is vested in himself. Hence the relation of the reputed lord to his copyholder is clearly defined; and as far as respects copyhold estates, many manors still exist.'

${ }^{151}$ Simply because rights of the lord of the manor have been registered in the land register does not mean that they, if contested, can be proved to exist.
} 


\section{CONSEQUENCES OF REPEAL - INCLOSURES ACTS 1773-1868}

If the Inclosure Acts are repealed this will not affect rights of common as such - albeit, these are dubious in many instances as well as being of little value today ${ }^{152}$ and some should be abolished (this will be dealt with in a subsequent article). However, if the Inclosure Acts 1845-68 are repealed, do any sections in these Acts need to be preserved? As to this:

- Awards. The nature of the Inclosure Acts 1773-1868 was of an award being made by the Inclosure Commissioners, which award was then encapsulated in legislation. Thus, any issues arising would be governed by the relevant Acts. However, since the last inclosure under these Acts was in 1914 (at the latest, although it may have been 1901), it is hardly likely any issue would be extant now ${ }^{153}$ and the repeal of all the Inclosure Acts (general, local, private) will not affect the factual situation prevailing under those awards or Acts - the same as with repeal of any legislation. ${ }^{154}$ Thus, this legislation can be repealed without prejudice to any award granted thereunder. Further, it should be noted that many awards were amended by way of appeal. Also, others were, in practice, changed (greatly) after the award since parties were entitled to exchange land (or agree to an extinguishment of rights, for money) which they often did. In other words, the award, itself, was, often, the basis for future alterations in order for the lord of the manor or commoners to secure a better personal position - the same being effected on the basis of consent. Finally, the Commissioners under the 1845 Act (s 152) could amend awards under local and private Acts and, doubtless, did;

- Allotments. The 1845 Act (as amended) has extant sections on allotments - ${ }^{155}$ including fencing. ${ }^{156}$ It is asserted that any sections in the Inclosure Acts 1845-68 on allotments need not be retained and, if otherwise, they should be re-stated in a modern Open Spaces Act which deals with allotments in a specific part of the same (see 7). ${ }^{157}$ Further, today, local councils tend to control allotments pursuant to local government legislation ${ }^{158}$ and they maintain them (including fencing) rather than individuals doing this (as in the past), recovering such cost from allotment holders as part of the latter's annual charge;

- $\quad$ Town \& Village Greens. The Inclosure Act 1857 Act, s 12 (extant) protects town and village greens from nuisances. ${ }^{159}$ This should be updated and placed in more modern legislation;

\footnotetext{
${ }^{152}$ See n 33. Also, Peek, n 10, p 359 (writing in 1867) 'The number of those having rights of common over such lands has undoubtedly diminished in modern times.'

${ }^{153}$ The Inclosure Act 1845, s 152 (rep) authorised the Inclosure Commissioners to remedy defects and omissions made in awards made under and local Acts or prior Inclosure Acts of 1836 and 1840 (rep). Hunter, n 10, p 155 who also noted that an application under the Commons Act 1876 would be the appropriate means of dealing with any incomplete proceedings under the 1845 Act (i.e. making a fresh application). See also Halsbury Laws, n 11, para 319 ('Inclosure Acts...largely obsolete').

${ }^{154}$ For the dearth of use of the sections on regulation in the 1845 Act, see Ivor Jennings QC who referred to ss 113-20 and that 'The Royal Commission has had its attention drawn to very few regulated pastures' by 1958, see RC, n 11, p 179. See also Halsbury Laws, n 11, vol 13, para 319 'The Commission...recommended that the provisions of the Inclosure Acts relating to inclosure, and the provisions of other Acts authorising inclosure without the sanction of Parliament, should be repealed, though without prejudice to existing schemes under them...Piecemeal repeal has taken place...'.

155 The following still exist, Inclosure Act 1845, s 72 (allotments for the repair of roads), s 73 (allotments for places of exercise and recreation, for labouring poor and other public purposes), s 74 (persons to whom allotments made, bound to maintain and permit the same to be used, and subject thereto shall be entitled to herbage), s 75 (payment of rent charge for allotment), s 83 (allotments to be fenced at expense of allotees), s 93 (use of allotments), s 94 (tenure), s 105 (allotments to be binding on all persons), s 106 (allotments to be in compensation of previous rights), s 107 (sub-division of allotments), s 108 (management of allotments by wardens), s 109 (allotments - letting), s 110 (determination of tenancy on non-payment of rent), s 111 (recovery of possession from tenant holding over), s 112 (allotment rents).

${ }^{156}$ See Inclosure Act 1848, s 12 (neglect of owner to fence). However, see the Inclosure Act 1852, s 14 (inclosure commissioners may direct that fencing not needed) and the Inclosure Act 1857, s 1 (fences may be dispensed with). It is suggested all these sections be repealed.

${ }^{157}$ What is needed is a general provision indicating that the party in whom allotments are vested may make byelaws to govern all aspects of maintaining the same (including fencing) and recover such costs by way of a reasonable charge imposed on the allotees.

${ }^{158}$ Hunter, n 10, p 225, noted that, under the provision of the Local Government Act 1894, 'nearly all recreation grounds set out under the Inclosure Acts since 1845, and many of the fuel allotments previously set out [i.e. which he had just discussed], will, by operation of [the 1894 Act], vest in, and come under the management of, parish councils or of their nominees, while in other cases, here the allotments are vested in trustees other than churchwardens and overseers, those trustees may, with the approval of the Charity Commissioners, transfer the allotments to the parish council.'

${ }^{159}$ See $\mathrm{n} 110$. This s 12 was extended by the Common Act 1876, s 29 (extant)(any person injuring a town or village green, or interrupting its use as a place for exercise, commits a public nuisance). The Local Government Act 1894 gave to the parish council the power to prosecute - as well as to make byelaws for the regulation of any village green under its control. See Hunter, n 10, pp 218-9.
} 
- $\underline{\text { Roads. }}$ The 1845 Act contains sections on public and private roads. ${ }^{160}$ However, today, public roads are governed by more modern highways legislation and many private roads have become public ones. If necessary, these sections (as modernised) should be re-stated in an Open Spaces Act (see 7).

In particular, it is asserted that all private and local inclosure Acts should be repealed since the 1845 Act was general law - one designed to effect a more balanced position on matters such as: (a) fencing; (b) public and private roads; (c) quarries; (d) maintaining hedges, ditches and embankments. However, the 1845 Act, as noted above, has been amended by other general law, such as highways legislation, that of quarrying material for roads, general provisions of law on hedges and ditches (including the Hedgerow Regulations SI 1997/1160) etc. Thus, the specific law of local and private Acts should be treated as superceded by all this general law and can be repealed. Also, there would have been very few local and private inclosure Acts post-1845 (i.e. 270 years ago) since the 1845 Act was less expensive and more expeditious.

In conclusion, all the sections of the Inclosure Acts 1733-1868 should be repealed or (if required) any extant sections re-stated in an Open Spaces Act (see below). So too, the Commons Act 1876 since the Commons Act 1899 became, after its enactment, the preferred vehicle for regulation. ${ }^{161}$ All local and private Acts should, also, be repealed without prejudice to any award made thereunder.

\section{AN OPEN SPACES ACT}

If the Inclosure Acts 1733-1868 are repealed, the opportunity should be taken to re-state all extant legislation on commons (including metropolitan commons), allotments, parks and gardens, town and village greens etc - much of which is very antiquated - in a consolidated Open Spaces Act (an ' $\boldsymbol{O S} \boldsymbol{A}^{\prime}$ ). ${ }^{162}$ Also, calling such a consolidation Act an OSA avoids the problem of trying to 'squeeze' the definitions of 'common' and 'common land' to include things such as parks, allotments and town and village greens etc. when this is no longer appropriate, since such have, over time, acquired their own legal features and legislative provisions. ${ }^{163}$ As to extant legislation, this would appear to be as follows:
(a) Parks \& Recreation Grounds ${ }^{164}$
- Recreation Grounds Act 1859; ${ }^{165}$
- Parks Regulation Act 1872 (various sections, as amended in 1926 (see s 2) \& 1974); ${ }^{166}$
- Public Health Act 1875 (s 164, places of public recreation); ${ }^{167}$

\footnotetext{
${ }^{160} 1845$ Act, s 67 (public roads to be repaired as other public roads, after certificate of completion given by 2 justices of the peace), s 68 (private roads, expenses of making and maintaining the same). See also Inclosure Act 1848, s 4 (see n 106). There are also sections dealing with roads in local and private Acts (which would have been pre-the 1845 Act in most instances). Attempts to rely on provisions relating to roads have, generally, failed since the fact situation has changed. See also Jessel Twenty First, n 12, pp 101-2. The same applies to hedges and ditches. Ibid, pp 104-9.

${ }^{161}$ Another Act also redundant (but extant) is the Commons Act 1908. The RC, n 11, p 180 (in 1958) stated that the Act was'only concerned with the regulation of the times and conditions for turning out entire animals...It has been little used. Only 17 cases have occurred, the last case being in 1936.' Clayden, n 11, p 49 'The scope of the regulations which can be made is narrow and the procedure has not proved very helpful in practice.' See also Halsbury Laws, n 11, para 501.

162 The RC (in 1958), n 11, recommended the repeal of some legislation. However, it would be been better (in hindsight) if they had recommended consolidation since the legislation tended to become even more tangled. See also Ibid, p 167 (Ivor Jennings QC) 'The law [on common land] is not always easy to follow, because though the common law is fairly simple it has been amended by a mass of statutes.'

${ }^{163}$ See Harris, n 11, pp 243-4 on the statutory definitions of common land. He noted, in particular, 'Section 16 of the Commons Act, 1899, provides that the expression 'common' shall 'include any land subject to be inclosed under the Inclosure Acts, 1845 to 1882, and any town or village green.' It is curious that this is an inclusive and not an exhaustive definition: the possibility, which must be remote, is left open that classes of common land exist other than those contained in the six categories set out in the Act of 1845 [i.e. the Inclosure Act 1845]. The inclusion of town and village greens is artificial and a matter of administrative convenience: town and village greens may or may not be subject to rights of common.'

${ }^{164}$ See Clayden Parks, n 11. Public parks only developed mid $19^{\text {th }}$ century in England and recreation grounds (for bowling greens, tennis courts, gyms etc) not until the late $19^{\text {th }}$ century, see Clayden, n 11, ch 1 . See also RJ Roddis, The Law of Parks and Recreation Grounds $\left(4^{\text {th }}\right.$ ed, 1974). See also Halsbury Laws, n 11, vol 78, para 340 et seq.

${ }^{165}$ Clayden Parks, n 11, p 10 'The [Act] empowered charities to provide open public lands for use as playgrounds (suitable for children and the youth) and land for adult recreation. Although the 1859 Act was repealed in full by the Charities Act 1960, a number of trusts of charity are still wholly comprised under the 1859 Act or within an instrument having effect under the Act. The operation of those trusts is not affected by the repeal. Consequently, although the 1859 Act was repealed in full, it is still relevant for some charities. Most of the earlier properties owned by the National Playing Fields Association are vested to them under the provisions of the 1859 Act.'

166 The Parks Regulation Act 1926 s 3 relates to Kew, see 7 (e) in the text.

${ }^{167}$ Clayden Parks, n 11, p 11 'Section 164...gave local authorities specific discretionary powers to provide and maintain public walks and pleasure grounds.' This was extended to all local authorities by the Local Government Act 1972, sch 14, para 27.
} 
- Public Health Acts Amendment Act 1890 (ss 44-5, parks and pleasure grounds);

- Public Health Acts Amendment Act 1907 (ss 76-7, parks and pleasure grounds);

- Public Health Act 1925 (s 56, parks and pleasure grounds);

- Public Health Act 1936 (ss 221-34, swimming baths);

- Physical Training and Recreation Act 1937 (ss 3, 8); ${ }^{168}$

- Public Health Act 1961 (ss 52-4, parks and pleasure grounds);

- Local Government (Miscellaneous Provisions) Act 1976 (ss 17-21, bathing, boating etc).

(b) London Open Spaces 169

- Corporation of London (Open Spaces) Act 1878 (a private Act); ${ }^{170}$

- Green Belt (London and Home Counties) Act 1938;

- Ministry of Housing and Local Government Provisional Order Confirmation (Greater London Parks and Open Spaces) Act 1967;

- City of London Corporation (Open Spaces) Act 2018.

(c) Town Gardens \& Squares 171

- Metropolis Management Act 1855 (s 239, inclosed gardens and squares); ${ }^{172}$

- Town Gardens Protection Act 1863 (ss 1-2, 4-5 \& 7, gardens in certain squares). ${ }^{173}$

(d) Royal Parks ${ }^{174}$

- Crown Lands Act 1851 (ss 22-3, royal parks);

- Law of Property Act 1922 (s 137, royal parks);

- Royal Parks (Trading) Act 2000 (ss 1-6, royal parks).

(e) Royal Botanic Gardens

- Parks Regulation (Amendment) Act 1926 (s 3, Kew);

- National Heritage Act 1983 (ss 23-9, Kew).

(f) National Parks ${ }^{175}$

- National Parks and Access to the Countryside Act 1949; ${ }^{176}$

- Countryside Act 1968; ${ }^{177}$

- Local Government Act 1972 (s 184, national parks);

- Nature Conservancy Council Act 1973;

- Wildlife and Countryside Act 1981; $;^{178}$

\footnotetext{
${ }^{168}$ This enables local authorities to acquire land for public recreation. See also the Local Government (Miscellaneous Provisions) Act 1976, s 19 (recreational facilities).

${ }^{169}$ The City of London owns and manages various parks. See Clayden, n 11, ch 10.

${ }^{170}$ Clayden Parks, n 11, p 134 'Under [the Act] the city was empowered to acquire common or commonable land and open space within 25 miles from the City boundary. Using these powers, the City has acquired Burnham Beeches in Buckinghamshire and Farthing Down and Coulsdon Common in the London Borough of Croydon.'

${ }^{171}$ For gardens in towns, including the London Square gardens, see Hunter Gardens, n 11, ch 6. He noted that the older London squares were laid out under private Acts of Parliament. See also Halsbury Laws, n 11, vol 78, para 330 et seq.

172 The section covers not only London but other cities and towns.

${ }^{173}$ Clayden Parks, n 12, p 10 'The [Act] empowers local authorities, in cities and towns, to take charge of enclosed gardens or ornamental grounds and either establish a management committee or maintain the grounds themselves. Management committees are able to make byelaws for the preservation of gardens or grounds...'.

${ }^{174}$ Ibid, ch 9 (he lists various royal parks). See also Halsbury Laws, n 11, vol 78, para 350.

${ }^{175}$ See generally, Halsbury Laws, n 11, vol 78, para 422.

${ }^{176}$ This Act reflects, in considerable part, what the Victorians meant when they referred to 'Open Spaces'. It is divided into the following parts: (a) National Park Commission; (b) National Parks; (c) Nature Conservation (nature reserve); (d) Public Rights of Way; (e) Access to Open Country; (f) General. For a text on the Act see RN Hutchins, The National Parks and Access to the Countryside Act 1949 (1950).

${ }^{177}$ It is divided into the following parts: (a) Natural Resources Body for Wales; (b) New Powers of Local Authorities; (c) Nature Conservation, National Parks and Access to Open Country; (d) Trees \& Woodlands; (e) Public Rights of Way; (f) General.
} 
- Norfolk and Suffolk Broads Act 1988;

- Environment Act 1995 (ss 61-79, national parks);

- Countryside and Rights of Way Act 2000; ${ }^{179}$

- Natural Environment and Rural Communities Act 2006;

- Marine and Coastal Access Act 2009. ${ }^{180}$

It is asserted that the entirety of all this legislation should be consolidated into an OSA - with roadside waste (see (k))being separated out. Further, Victorian expressions such as 'pleasure grounds' are no longer needed since we, generally, refer to 'parks' and to 'recreation grounds' - albeit the latter are (often) located in parks. ${ }^{181}$ Also, in the case of national parks (e)), it is asserted that such material can now be divided up in modern legislation in a more 'user friendly' manner, viz.

- Commissions \& Bodies;

- Powers;

- National Parks;

- Nature Reserves; ${ }^{182}$

- Marine Reserves, ${ }^{183}$

- Sites of Special Scientific Interest (SSI); ${ }^{184}$

- Areas of Outstanding Natural Beauty; ${ }^{185}$

- Countryside Access;

- Public Rights of Way;

-Wildlife Protection;

- Trees \& Woodlands;

- General.

(g) Town \& Village Greens ${ }^{186}$

- Inclosure Act 1857 (s 12, protects town and village greens from nuisances);

- Commons Act 1876 (s 29, extends s 12 above);

- Commonable Rights Compensation Act 1882 (s 3, compensation);

- Local Government Act 1972 (s 189, village greens).

Material on town and village greens should be separated out from the material on commons, since it is, now, a distinct area. ${ }^{187}$

\section{(h) Recreation Grounds (Plaving Fields)}

The Recreation Grounds Act 1859, still extant, enabled land (often, from manorial waste) to be set aside for recreation grounds (often, also called playing fields). Under the 1845 Act, inclosure awards could also allot land

\footnotetext{
${ }^{178}$ It is divided into the following parts: (a) Wildlife; (b) Nature Conservation, (c) National Parks and Countryside; (d) Public Rights of Way; (e) General

${ }^{179}$ It is divided into the following parts: (a) Right of Access; (b) Exclusion or Restriction of Access; (c) Public Rights of Way; (d) Nature Conservation and Wildlife Protection; (e) Areas of Outstanding Natural Beauty. See also Jessel Twenty-First, n 12, chs 2 \& 3.

${ }^{180}$ See also Halsbury Laws, n 11, vol 78, para 414 et seq.

${ }^{181}$ See also (h), below.

${ }^{182}$ See generally, Halsbury Laws, n 11, vol 78, paras 448, 455-6.

${ }^{183}$ Ibid, para 451.

${ }^{184}$ Ibid, vol 13, para $512 \&$ vol 78, paras 457-80.

${ }^{185}$ Ibid, paras 443-7.

${ }^{186}$ See $\mathrm{n} 11$. See also RC (in 1958), n 11, pp 118-9, 135, 171 and Ubhi, n 11, ch 9. See also Halsbury Laws, n 11, vol 78, para 314 et seq.

${ }^{187}$ Commons Registration Act 1965, s 22(1) (prospectively repealed by the Commons Act 2006, sch 6, pt 1). See also Harris, n 11, pp 27-8. RC, $\mathrm{n} 11, \mathrm{p} 171$ 'a village green or roadside green is not necessarily common land...It may be....an area around which the villagers' houses were built and over which they have by immemorial custom enjoyed the privilege of playing lawful games and otherwise having recreation. Again, it may merely be part of the highway....' See also Halsbury, note 11, vol 13, para 301, fn 1. See also Jessel Twenty-First, n 12, ch 1.
} 
for recreation, with provision being made for fencing. ${ }^{188}$ Sometimes the award was to a private owner, subject to a public right of recreation. However, as Baker noted, this proved unsatisfactory and was discontinued after 1876. ${ }^{189}$ Often, though, such land was allotted to the churchwardens and overseers of the parish and this, later, passed to local councils under the Local Government Act 1894, s 6 (rep). ${ }^{190}$ Further, fuel allotments under inclosure awards, often, became village greens, recreation grounds or field gardens (i.e. garden) allotments. Today, any material on recreation grounds, to the extent the same do not comprise a park, town or village green or allotment, should be set out in the OSA, with provision on byelaws and management. Further, the Recreation Grounds Act 1859 should be repealed as spent. Where possible, recreation grounds should be treated no different to parks, with similar byelaws etc (it may also be noted that many recreation grounds, today, are not fenced as such).

\section{(i) Metropolitan Commons}

The Metropolitan Commons Act 1866 - ${ }^{191}$ which, at one time, had been intended to be called the Suburban Commons Act 1866 - precludes the inclosure of commons within the London metropolitan police district ('MPD). That was (originally) within 15 miles of a radius from Charing Cross; it now refers to London borough councils. $^{192}$ Thus, the Inclosure Act 1845 (as amended) does not apply. ${ }^{193}$

- The commissioners under this Act are stated to be the Inclosure Commissioners of England and Wales appointed under the 1845 Act (now, the Secretary of State for the Environment). The process is for a scheme $^{194}$ to be presented for the improvement of a metropolitan common. This, when approved by the commissioners, is referred to Parliament for approval - which scheme has all the incidents of a private bill;

- Such schemes can be amended by proceedings similar to those adopted with reference to the original scheme. $^{195}$

It is asserted this Act should be repealed ${ }^{196}$ and all commons (whether in London or in any urban areas) should be dealt with in a similar fashion, in an OSA.

\footnotetext{
1881845 Act, s 73. See also Halsbury Laws, n 11, vol 78, para 334 et seq.

189 Baker, n 11, p 7.

${ }^{190}$ Ibid, pp 7-10.

191 This Act was amended by the Metropolitan Commons Amendment Act 1869 and supplemented by the Metropolitan Commons Act 1878. This Act came about because, in 1865, Earl Spencer (as lord of the manor of Wimbledon) sought to dedicate to the use of the public the greater portion of Wimbledon common. However this involved selling part of it for development purposes. The Earl asserted that, in effect, he had unimpeded ownership rights as lord of the manor. However, commoners and other interested parties strongly opposed this - as well as the destruction of other 'open spaces' within London such as Blackheath, Hampstead Heath, Wandsworth Common etc. This issue gave birth to the Act as well as to the Commons and Footpaths Preservation Society (Open Spaces Society) in whose offices the National Trust was established. See Eversley, n 12, where the story is well told, see also ch 20 of the same for the Metropolitan Commons Act 1866. See also Hunter, n 10, ch 22.

${ }^{192}$ The Metropolis Management Act 1855, s 5 (extant). It now refers to 'a metropolitan common which is under the management and control of a London borough council or any part thereof.'

${ }^{193}$ Peek, $\mathrm{n} \mathrm{10, \textrm {p }} 75$ 'The idea of the Act is that with a view to securing permanently as many as possible of the metropolitans commons intact for the benefit of the public, schemes for that purpose, specially adapted to the circumstances of each common, and the several rights of the persons interested therein, should be proposed by the lord of the manor or any of the commoners, or the 'local authority' of the district where the common in question is situate, and that such [a] scheme when settled and perfected as far as it can be, should be submitted to Parliament for the confirmation, and should then become binding as law; but every scheme must provide for due compensation being given to all persons whose private rights would be injuriously affected by the measures proposed. The Act contains further provisions to enable the Crown to deal freely with its manorial and other rights affecting the metropolitan commons.' Ibid, p 143.

${ }^{194}$ Metropolitan Commons Act 1866, s 6 'A scheme for the establishment of local management with a view to the expenditure of money on the drainage, levelling, and improvement of a metropolitan common, and to the making of by-laws and regulations for the prevention of nuisances and the preservation of order thereon, may be made under this Act, on a memorial in that behalf presented to the commissioners by the lord of the manor or by any commoners, or by the local authority, or in the case of a common extending into the districts or two or more of the bodies described in the first schedule to this Act, then by any one or more of such bodies.'

${ }^{195}$ Ibid, s 27. Eversley, n 10, p 324 (writing in 1910) preferred these Acts to the Commons Act 1876 because any scheme under the latter could be vetoed by the lord of the manor and two thirds of the commoners. See also Hunter, n 10, ch 22 (position in 1902). It may also be noted that this Act could be circumvented by a special Act. Peek, n 10, p 287 'The Act...does not interfere with the power of Parliament to pass special acts, authorising the inclosure of any open lands wherever situated.'

${ }_{195}$ As to the slowness and expense of such a procedure this was adverted to as early as 1867, see Peek, n 10, p 369. Also, that it did not apply to other large towns. Ibid, p 370.

${ }^{196}$ It may be noted that the RC (writing in 1958), n 11, p 134 recommended that the Metropolitan Commons Acts 1866-98 should be repealed. However, this was (unfortunately) not carried out.
} 


\section{(j) Allotments ${ }^{197}$}

Garden allotments ('allotments') ${ }^{198}$ became popular in Victorian times ${ }^{199}$ and (much) more so after the $1^{\text {st }}$ World War. ${ }^{200}$ Older terms for allotments were 'field gardens' and 'allotment gardens'. Many allotments derived from manorial waste, including where local authorities used compulsory powers to acquire the same. ${ }^{201}$ In the early part of the $20^{\text {th }}$ century, a large number of allotments were run by local authorities ${ }^{202}$ - although there were also statutory companies (societies or associations had to be registered under the Industrial and Provident Societies Act 1893) and private landowners, as Mitchell indicted, in his text in 1922. Also, some were run by charities or the Ministry of Education. Today, local councils tend to be involved in most. In that era, the legislation on allotments was piecemeal and there were model rules, with detailed provisions on rent and maintenance etc. ${ }^{203}$ Little has changed. Extant legislation dealing with allotments comprises:

- Commons Act 1876 (ss 26-8);

- Commons (Expenses) Act 1878 (s 4);

- Commons Act 1879 (s 2); ${ }^{204}$

- Commonable Rights Compensation Act 1882 (s 3, compensation); ${ }^{205}$

- Commons Act 1899 (ss 16 \& 18, field gardens);

- Small Holdings and Allotments Act 1908 (various sections);

- Land Settlement (Facilities) Act 1919 (ss 9-25 amend the 1908 Act above, also s 28);

- Allotments Act 1922 (various sections);

- Allotments Act 1925 (ss 1,5,7-9);

- Small Holdings and Allotments Act 1926 (various sections);

- Agricultural Land (Utilisation) Act 1931 (ss 12,17, 20); ${ }^{206}$

- Allotments Act 1950 (various sections).

At present, the law on allotments is unduly muddled and difficult to read, due to a mishmash of legislation, as can be seen from Halsbury's Laws and Statutes. These Acts should be modernised and placed in an OSA. ${ }^{207}$

\footnotetext{
${ }^{197}$ For older texts on allotments, see: (a) SW Clarke, Small Holdings in England and Wales (1908); (b) WH Dumsday, Law of Allotments and Small Holdings (1909); (c) CD Forster, Small Agricultural Holdings Act, 1892 (1892); (d) JF Garner, The Law of Allotments (1963); (e) TH Hall, Law of Allotments (1866) ('Hall') and TH Hall, The Allotments Act 1887; (f) GA Johnston, Small Holdings and Allotments ( $1^{\text {st }}$ ed, 1908); (g) JB Little, Law of Allotments ( $1^{\text {st }}$ ed, 1887); (h) EL Mitchell, The Law of Allotments and Allotment Gardens (1922); (i) AJ Spencer, The Small Holdings Acts $\left(1^{\text {st }}\right.$ ed, 1892, $4^{\text {th }}$ ed, 1927). See also Harris, n 11, p 29 'allotments are former common land, over which the rights of common have been deliberately extinguished...' For a modern analysis see Halsbury Laws, n 11, vol 1, para 649 et seq.

${ }^{198}$ Victorian legislation tended to refer to: (a) recreational allotments; (b) fuel allotments; and (c) field garden (garden) allotments. Today, we think of allotments in terms of (c). Much of (a) and (b) later became (c) or parks, village gardens or playing fields. Today, any remaining allotments in (a) or (b) not otherwise falling into these other categories are better treated as common land. See also RC (in 1958), n 11, pp 119-21, 135. Also, Baker, n 11, pp 9-10.

199 As Garner, n 197, p 1, noted, the word 'allotment' meant a share of land allocated (or allotted) to a person pursuant to an inclosure award. Thus, field garden allotments were gardens (i.e. land for cultivation) not exceeding a quarter of an acre which were allocated by the Inclosure Commissioners for the labouring poor by the Inclosure Act 1845, s 31 .

${ }^{200}$ Mitchell, n 197, p vii (in 1922) noted that there were 1.3m allotments in England and Wales in 1920 of which 500,000 were tenants of private owners.

${ }^{201}$ See Mitchell, n 197, ch 3. See also Small Holdings and Allotments Act 1908, s 39(7).

${ }^{202}$ In London, this was the London County Council and the Metropolitan Borough Councils. In urban and rural districts, it was the local council - whether urban or parish. For the position in respect of allotment associations by 1963, see Garner, n 197, ch 10.

${ }^{203}$ Mitchell, n 197, pp 134-8.

${ }^{204}$ Section 2 (application of surplus rents of recreation grounds) 'The improving the field gardens, or any of them, to which the [Commons Act $1876, \mathrm{~s} 27$ ] applies, in the same parish or neighbourhood, or maintaining the drainage and fencing thereof, shall be one of the purposes to which the surplus rents arising from recreation grounds shall be applied.'(italics supplied)

${ }^{205}$ For ss 2, 4-5 see n 217.

${ }^{206}$ This made minor amendments to prior Allotment Acts.

${ }^{207}$ In such, a 'garden allotment' should, nowadays, only refer to a small plot of land allocated for cultivation. Other allotments (fuel allotments, poor allotments, gravel allotments etc) if not now village greens or parks should be categorised as common land. Further, garden allotments should be distinguished from an 'agricultural holding', 'agricultural land' and a 'farm business tenancy', where required. New legislation on garden allotments should have inter alia, the following parts: (a) Provision of land for garden allotments (i.e. who is required to provide land for the same); (b) Acquisition of land for garden allotments; (c) Compulsory acquisition of land for garden allotments; (d) Renting (hiring) land for
} 
Further, much of this material could be placed in a Statutory Instrument, to ensure easier updating. There should also be 'model' allotment rules (in a SI). Also - unlike in the past when there was individual fencing - this issue of fencing today (and whether needed) should be for the manager of the allotment to determine (with the allotment holders).

\section{(k) Roadside Waste ${ }^{208}$}

This has become a distinct area as opposed to common land and it should be set out as such.

(l) Common Land 209

With the decline in common arable (i.e. agricultural) fields (also called, open fields) by late Victorian times (and Laxton only remaining today, see 5(a)) it was inevitable that legislation on commons post-1876 was mainly concerned with manorial waste. ${ }^{210}$ The following legislation extant applies to common land:

- Commons Act 1876 (various sections); ${ }^{211}$

- Commons (Expenses) Act 1878 (s 2, expenses of regulation); ${ }^{212}$

- Local Government Act 1894 (s 26, power of council re commons); ${ }^{213}$

- Commons Act 1899 (various sections);

- Open Spaces Act 1906 (various sections); ${ }^{214}$

- Law of Property Act 1922, (ss 144 \& 144A, manorial documents);

- Commons Registration Act $1965 ;^{215}$

- Countryside Regulation Act 1968 (s 9, common land);

- Commons Act 2006 (various sections).

And, the following material relates to 'rights of way' (including public, animal and vehicle access) in respect of common land. It should be set out separately:

- Commons Act 1908 (s 1, regulations on entire animals on common land). ${ }^{216}$

- Law of Property Act 1925 (s 193, rights of the public over common land);

- Caravan Sites and Control of Development Act 1960 (s 23, caravans on common land);

- Mobile Homes (Wales) Act 2013.

Also, a separate heading should deal with the acquisition of common land. Such should be included since all this legislation should be consolidated in an OSA so that there are standard (and consistent) provisions, see

- $\quad$ Land Clauses Consolidation Act 1845 (ss 99-107, acquisition);

- Commonable Rights Compensation Act 1882 (ss 2, 4-5, compensation); ${ }^{217}$

garden allotments; (e) Who may manage garden allotments; (f)) Management of garden allotments (rent, terms of tenancy, termination of tenancy etc); (g) Change of use of garden allotments.

${ }^{208}$ See also Baker, n 11, pp 10-2. Also, Harris, n 11, p 13 and Commons Registration Act 1965, s 22(1)(definitions of common land and rights of common), which definitions excluded roadside waste.

${ }^{209}$ For Victorian texts, see ns 9 and 10.

${ }^{210}$ See, for the development of common land in the $20^{\text {th }}$ century, RC, $\mathrm{n} 11$ which Report led to the Commons Registration Act 1965 . This Act required county registration authorities to receive and register claims to the ownership of common land and rights of common. See also, Denman, n 24 (a study in land use, conservation and management based on a national survey of commons in England and Wales 1961-1966).

211 As previously noted, in respect of regulation, the Commons Act 1876 is effectively spent, this now being covered by the Commons Act 1899.

212 This Act is effectively spent.

${ }^{213}$ This also referred to rights of way and to roadside waste.

${ }^{214}$ Clayden Parks, n 11, p 13 'The [Act] gave powers to trustees under local Acts of Parliament to transfer open spaces, recreation grounds and disused burial grounds to local authorities. Local authorities were given power to acquire by agreement open spaces and disused burial grounds and to manage such areas for public benefit. An open space was defined to include not only land used for recreation but also land laid out as a garden or which was waste and unoccupied.'

215 This Act is intended to be prospectively repealed by the Commons Act 2006.

${ }^{216}$ See s 1 (power to make regulations re the turning out of entire animals on commons), s 2 (application to Dartmoor). 'Entire' animals refer to uncastrated males.

${ }^{217}$ viz s 2 (compensation for common lands), s 4 (where money already paid), s 5 (deposit of orders). Sections 4-5 are spent. 
- Light Railways Act 1896 (s 21, acquisition);

- Compulsory Purchase Act 1965 (s 21, acquisition);

- Local Government Act 1972 (s 121-3, appropriation);

- Acquisition of Land Act 1981 (s 19, acquisition).

In the past, there was confusion as to what terms such as 'commons', 'common land', 'common fields', 'open fields' etc meant. ${ }^{218}$ Further, these terms did not mean that the land had to be physically inclosed (i.e. fenced or hedged or ditched in) to be such (the same still applies today). ${ }^{219}$ Thus, the reference, really, is to the extinction of common rights (including rights of common). ${ }^{220}$ If all the above material is consolidated into an OSA, then, 'common land' can be more easily defined. Thus, it could comprise land - whether manorial waste or not - ${ }^{221}$ which is: ${ }^{222}$

- manorial waste; or

- land subject to rights of common; or

- land subject to public access; or 223

- land grazed in common (including where the owner is excluded), such as:

(i) lammas land; 224

(ii) lot meadows; 225

(iii) stinted pastures; ${ }^{226}$

(iv) land where the vesture, herbage or timber are owned other than by the landowner, ${ }^{227}$

\footnotetext{
${ }^{218}$ See RC (in 1958), n 11, pp 23 'Though the term is used both popularly and in terms of reference, 'common land' has no precise meaning. It might be defined narrowly as land subject to common rights or, even more narrowly (to distinguish between 'common land' and 'commonable land'), as land subject to common rights at all times of the year. Neither meaning would accord with popular usage, and for that reason it appeared convenient to adopt a wider meaning.' The RC, Ibid, p 273 defined 'commonable land' as 'Usually nowadays certain lands other than manorial waste over which rights of common exist at particular times of the year.' Ubhi, n 11, p 2, n 1 'The expression 'common land' has particular meanings under different situations.' See also Halsbury Laws, n 11, vol 13, para 306.

${ }^{219}$ See RC, n 11, pp 23-4 'land which is not enclosed or fenced is by no means necessarily subject to common rights'. Also, Harris, n 11, p 4. ${ }^{220}$ Ibid, p 173 'It may have been noticed that in surveying the history we have changed the meanings of 'inclosure'. Literally it means putting up fences or walls or planting hedges around a piece of land...the essence of inclosure, as the term is now used, is the extinction of common rights.'

${ }^{221}$ It is possible to have manorial waste with no rights of common, because they have been bought out, lapsed or not been registered. It is also possible to have rights of common that are not manorial - because the owner of the land is unknown or because the land was never manorial. See also RC, n 11, pp 167-71 (especially, paras 18 \& 21). Ibid, p 167 who noted generally that 'there are common lands with no known owners, common lands whose ownership is in dispute, reputed common lands which have no known commoners, lands which are alleged by some to be common lands and by others not to be subject to common rights, lands on which there were and probably still are common rights but which are claimed to be free of common rights, and so forth.' See also Commons Registration Act 1965, s 22(1)(definitions of common land and rights of common), inc manorial waste not subject to rights of common. Also, Harris, n 11, p 7.

${ }^{222}$ See the 8 categories of the RC (in 1958), n 11, p 24. They referred to: (1) land subject to common rights; (2) land grazed in common by persons owning the soil in common [i.e. common fields], where the lord of the manor might (or might not) also own the soil (or part); (3) land grazed in common to the exclusion of the owner of the soil (i.e. land subject to sole vesture or pasture); (4) town and village greens; (5) manorial waste open to public access; (6) roadside waste; (7) allotments; (8) land held on charitable trusts for purposes similar to (7). Those in italics should not be treated as common land, as such, today. Also, common (arable) fields (i.e. Laxton, see 5(a)), should be treated separately, since it should be capable of being inclosed (i.e. the commonalty extinguished) by agreement (see $\mathrm{n}$ 125). The likelihood of arable land, in the future, being changed back to a common field system may be dismissed as very low indeed. Lammas land (see n 34) is said to be a type of lot meadow at times. However, this is not (actually) so. Lammas goes to duration (the time period for which the land is communally open), lot goes to allocation (how the communal land is allocated, by lot). See Harris, n 11, pp 17-8.

${ }^{223}$ Ibid.

${ }^{224}$ See Halsbury Laws, n 11, vol 13, para 314. They also note, Ibid 'most Lammas lands are now pasture and not arable.'

${ }^{225}$ Ibid, para 315. Ibid, 'In practice most such lands are now pasture and not arable.' See also shack land, Ibid, para 315.

${ }^{226}$ Ibid, para 317. Also, para 480 et seq.

${ }^{227}$ See 1845 Act, s 11. This would cover all: (a) gated and stinted pastures; (b) all land held, occupied or used in common; (c) all land in which ownership of the vest, herbage and trees belonged other than to the landowner; (c) all lot meadows. As to vesture etc, see RC, n 11, p 171 'The owner of the soil, may, however, grant the sole vesture, the exclusive right to take the produce of the soil, or the sole pasture, the exclusive right to graze animals on the soil, to another in fee simple; or he might make the same grant in copyhold.' Such could also be granted to several persons in common. They could also arise by way of prescription. See also Ibid, pp 175-6. See also the Commons Registration Act 1965, s 22(1)(definitions of common land and rights of common). Finally, 'gated' is synonymous with 'stinted'. Thus, only one term is needed. Stinted goes to the number of animals permitted to graze - as opposed to duration or lot.
} 
but excluding all (common) parks, ${ }^{228}$ town and village greens, allotments and roadside waste etc save where the OSA otherwise provides. It is suggested 'common land' is a better term than 'commons'. Also, in an OSA, the term 'inclosure' (enclosure) is no longer needed. The issue, today, is better expressed in terms of a 'change of use' - that is, from common land. Also, terms such as 'commonable land', 'commonable beasts', 'levant and couchant', 'appurtenant', 'vicinage' etc. are no longer useful and should be dispensed with. ${ }^{229}$ Finally, the prevailing principle would be that first reflected in the Commons Act 1876. Common land remains so unless: (a) extinguished pursuant to a scheme approved by Parliament; (b) only where certain specific exceptions apply.

(m) Dartmoor, Forest of Dean, New Forest, Epping Forest

In the past, specific legislation covered these matters. Today, such should be included in an OSA (in Appendices) save where the older legislation relates to mining (and gale rents). ${ }^{230}$ Extant legislation comprises:

- Dean and New Forest Act 1808 (ss 3 \& 4, inclosure);

- New Forest Act 1877;

- Epping Forest Act 1878;

- New Forest Act 1879 (s 2, pasturing cattle);

- Dean Forest Act 1906 (s 1, power to exchange parcels of waste);

- Commons Act 1908 (s 2, Dartmoor); ${ }^{231}$

- New Forest Act 1949;

- New Forest Act 1964;

- New Forest Act 1970 (ss 1-3, 5); ; $^{232}$

- Dartmoor Common Act 1985 (ss 1-23);

(n) Military and Crown Land

Legislation relating to military land should be modernised and consolidated in a distinct Armed Services Act. This could be undertaken by the Ministry of Defence. ${ }^{233}$ Crown land should be included in a Crown Act (including Crown Estate material). ${ }^{234}$

\section{(o) Conclusion-OSA}

In conclusion, there should be an OSA which gathers together all this material in one consolidation Act (and putting a lot in SI's). Thus, it is suggested that the OSA deals with (in separate parts):

- Parks (including recreation grounds);

- London parks (including gardens in squares);

- Royal parks;

- Royal botanic gardens;

- National parks;

- Town \& village greens;

- Garden allotments;

- Roadside waste;

- Common Land (inc. metropolitan commons) (a residual category);

\footnotetext{
${ }^{228}$ Obviously, parks can be private as well as common (public). However, legislation refers to 'parks' dropping the 'common'.

${ }^{229}$ As long ago as 1958 (60 years ago), RC, n 11, (Ivor Jennings QC), p 175 noted this 'it seems certain that some 'commonable lands' have remained fallow since the middle of the nineteenth century if not since the extension of sheep-farming in the Tudor period. Nor indeed is the legal distinction between 'commonable beasts' and beasts which are not commonable of much practical importance; nor has 'levant and couchant' much practical meaning in an age which knows silage and oil-cake.'

${ }^{230}$ The Dean Forest Acts 1819 (ss 7 \& 8) \& 1861 relate to gale rents. So too the Dean Forest Act 1906, s 2.

${ }^{231}$ This s 2 (application to Dartmoor) should be placed in a section in the Open Spaces Act dealing with Dartmoor.

${ }^{232}$ It may be noted that some of the legislation on common land (see $(\boldsymbol{l})$ in the text), sometimes, makes specific provisions on these forests and Dartmoor, or excepts them.

${ }^{233}$ For the legislation see $\mathrm{s} 8$.

${ }^{234}$ See Appendix B(f).
} 
- General;

- Dartmoor, ${ }^{235}$ New Forest, ${ }^{236}$ Forest of Dean, ${ }^{237}$ Epping Forest ${ }^{238}$ (in Appendices).

(If it is thought that such legislation might be too large, then, the material on parks (including national parks) could be placed in an Act of that name and the material in italics placed in a Town and Village Greens, Garden Allotments and Common Land Act). Further, modern terms should be employed (e.g. common land should be defined to exclude all the above, save where the OSA otherwise provides. Also, in the past, there had been confusion as to issues such as:

- whether land is (or is not) a park, town or village green, allotment, common land etc or - if it is - the nature (and extent) of public access or a right of way over the same; 239

- the nature (and extent) of any right of common.

Thus, the Lands Tribunal should have jurisdiction to appoint an arbitrator to arbitrate on all matters arising under the OSA as well as to any alleged right of common, right of access, right of way etc - as well as any issue in respect of any award formerly made under prior Inclosure Acts (i.e. those of 1733-1868) and Commons Acts (i.e. those from 1866 onwards). This, with the emphasis on the simplicity, speed and modest cost of the arbitral process. Also, with a right of appeal to the Court of Appeal (obviating additional cost incurred by any prior appeal to the High Court). ${ }^{240}$

In conclusion, with the repeal of the Inclosure Acts 1733-1868 amendment will need to be made to the above as well as to later Commons and other Acts, all of which should now be consolidated in an OSA. This would remove (very) much dead material and make the treatment of the law in this area more intelligible and consistent.

\section{STATUTE OF QUIA EMPTORES 1290}

\section{(a) Introduction}

It is trite law that - as from the Norman Conquest (1066) - all land was owned by the Crown since William I $(1066-87)$ asserted title to England. William, then, granted away land to his followers in return for services. ${ }^{241}$ Thus, such tenants (about 1500 or so of them in 1086) - being in capite (i.e. holding directly of the Crown) were bound to Crown for their land which included the giving of oaths of homage and of fealty (allegiance) in exchange for the same. ${ }^{242}$ The forms of land service (tenure) ${ }^{243}$ were:

- knight service, ${ }^{244}$

- sarjeanty (grand and petit); ${ }^{245}$

\footnotetext{
${ }^{235}$ See also P Birkett, A Short History of the Rights of Common upon the Forest of Dartmoor and the Common of Devon (1885).

${ }^{236}$ See also: (a) P Lewis, Historical Inquiries concerning Forest and Forest Law (1811); (b) C Gale, J Barstow \& JD Coleridge, New Forest Register of Decisions on Claims in Forest Rights (1858); (c) FE Kenchington, The Commoner's New Forest (1942)(appendices).

${ }^{237}$ See also: (a) HG Nicholls, The Forest of Dean (1858); (b) CE Hart, Forest of Dean and Hundred of St Briavels (1947). Also, The Commoners of Dean Forest (1951); (c) JG Wood, Laws of the Dean Forest and Hundred of St Briavels in the County of Gloucester (1878, supplement by OL Hart, 1952).

${ }^{238}$ See also WR Fisher, Forest of Essex (1887) and R Hunter, Epping Forest Act (1878). This forest (part of the royal forest of Waltham) had few rights of common viz. (a) pasture; (b) pannage; and (c) gravel extraction (but not for highways, s 35).

${ }^{239}$ See on this, RC, n 11, pp 31-3.

${ }^{240}$ Cf. pp 96-8 (recommendation $r e$ 'commons commissioner'). Such a description would not be appropriate to parks, allotments etc if not now termed common land as such.

${ }^{241}$ See also: (a) C Harpum et al (eds), Megarry and Wade, The Law of Real Property (8 ${ }^{\text {th }}$ ed, 2012), ch 2; (b) SFC Milsom, Historical Foundations of the Common Law ( $2^{\text {nd }}$ ed 1981); (c) AWB Simpson, An Introduction to the History of the Land Law (2 ${ }^{\text {nd }}$ ed, 1986); (d) EH Burn \& J Cartwright, Cheshire \& Burn's Modern Law of Real Property (18 ${ }^{\text {th }}$ ed, 2011)('Cheshire').

${ }^{242}$ The oath of homage (a military oath) tended to be only given if the tenure was that of knight service. However, it could also be given (more rarely) in the case of common socage. Homage was abolished by the Tenures Abolition Act 1660. See Jenks, n 6, p 15, n 2. See also (for the oath of homage), Coke, n 9, vol 1, s 85 (Co Litt 64a). Also, Cheshire, n 241, p 33 and Simpson, n 241, pp 15-6.

${ }^{243}$ Harpum, n 241, p 23 'Each of these sets of [feudal] services [e.g. knight service etc] was known as a tenure, because it showed upon what terms the land was held (tenere, to hold)'. See also Coke, n 9, vol 1, s 1 (Co Litt 1a).

${ }^{244}$ JG Riddall, Land Law (2003), p 13 'A tenant who held by the tenure of knight service was originally obliged to provide his lord with a specified number of fully armed horsemen. By the middle of the twelfth century the obligation to provide men had largely been commuted for a fixed money payment, termed 'scutage'. By the end of the Middle Ages, with the decline in the value of money, scutage had largely ceased to be collected.' See also Simpson, n 241, pp 3, 7-8..

${ }^{245}$ Ibid, p 13 (grand sarjeanty) 'A tenant who held by the tenure of grand sarjeanty did so in return for performing some service of an honourable character, e.g. holding an office of state, such as that of chamberlain, or performing a particular service, as at the king's coronation.
} 
- frankalmoign and divine service; ${ }^{246}$

- common socage, ${ }^{247}$ the latter being the residual tenure.

However, such grants of land were then (often) sub-granted on a similar basis. Riddall, in his text on Land Law, described the situation:

By means of granting land the king was able to provide himself with the greater part of his army, to garrison his castles, to fill the great offices of state, to provide for the principal servants of his household, and to obtain supplies of various provisions....Those who had received grants of land direct from the king were tenants-in-chief [in capite]....King William [I] granted land to about 200 [in fact, more likely, 1500] tenants-in-chief. Most of these in their turn granted away lands to inferior tenants, who themselves made grants to tenants of their own, and so the process (known as 'subinfeudation') was repeated down the scale. The system of land holding after the Conquest thus came to resemble a vast pyramid, at the apex of which stood the Crown. ${ }^{248}$

In such a system, the king was the lord paramount. Intermediate tenants not in possession were called mesne lords and overlordship was termed a seignory. ${ }^{249}$ The land system was, therefore, tenurial - referring to the holding of land from a superior in return for services to be provided by the tenant. ${ }^{250}$ As for subinfeudation - the process by which A (the king) granted land to B to hold as a tenant and B granted it to $\mathrm{C}$ to hold as his tenant etc - this was not invariable. It could be prohibited in the grant of land. ${ }^{251} \mathrm{Also}, \mathrm{B}$ could grant the land to $\mathrm{C}$ by way of substitution, in which case $\mathrm{C}$ held as a tenant to $\mathrm{A}$ not $\mathrm{B} .{ }^{252}$

\section{(b) Problem with Subinfeudation}

The problem with subinfeudation was that the overlord (including the Crown as lord paramount) lost the tenurial service (including the money equivalent, since many services had been converted into money). Riddall noted:

The process of subinfeudation...caused loss to superior lords, including, of course, the supreme feudal lord, the king. In 1290 it was therefore enacted by the Statute Quia Emptores that henceforth, when the holder of a fee simple transferred his land to another in fee simple, it should be by way of substitution, and not by way of subinfeudation. Thus the process of subinfeudation, which had formed one of the principal characteristics of the structure of land holding since the Conquest, was cut short. After the Statute, if B granted Blackacre to $\mathrm{C}$ in fee simple, $\mathrm{C}$ could not hold the land as tenant of $\mathrm{B}$, he held it as tenant of B's lord, A. The Statute provided that C should hold the land from A for the same service as that for which it had been held by B. The Statute did not prevent the king from granting land to tenants to hold of him as lord. Indeed, the king [i.e. the Crown] could not transfer the land by means of substitution, as [since] there was no lord above the king. ${ }^{253}$

\footnotetext{
'Ibid, p 14 (petty serjeanty) 'When the king granted land to a tenant in return for services of a non-personal nature, such as carrying his letters, or feeding his hounds or hawks, or providing him with arrows, or straw for his bed, then the tenant held by the tenure of petty sarjeanty.' Grand sarjeanty was a military tenure. See also Harpum, n 241, p 24, Cheshire, n 241, p 40 and Simpson, n 241, p 9-10, 13-4.

${ }^{246}$ See Harpum, n 241, p 24, Riddall, n 244, p 13 and Simpson, n 241, p 10.

${ }^{247}$ Ibid, p 14 (commons socage) 'The service most commonly rendered under this form of tenure was of an agricultural character, both the nature (e.g. ploughing) and the amount (e.g. 20 days a year) being fixed. But the services were not necessarily of an agricultural nature, and many other kinds are recorded. In towns a form of common socage existed under which money rents were rendered instead of services. This form of common socage is termed 'burgage tenure'. Common socage was a residuary class of free tenure: if the free tenure was not provided to be of the others, then it was held to be in common socage. By the end of the fifteenth century the services rendered in payment in connection with common socage had largely been commuted into money payments, sometimes called 'quit rents' (by which the tenant became quit of his services). Like scutage, by the end of the Middle Ages quit rents had largely ceased to be collected.'

${ }^{248}$ Riddall, n 244, pp 8-9. See also Harpum, n 241, p 25.

${ }^{249}$ Harpum, n 241, p 23 'Tenants in chief were those who held directly of the king...Those who in fact occupied the land were called tenants in demesne. Those who stood between the king and tenants in demesne were called mesne lords or mesnes (mesne, pronounced 'mean', meaning intermediate). The king was lord paramount. The status of lordship, including the right to receive the tenant's services, was called seignory.'

${ }^{250}$ Riddall, $\mathrm{n} 244$, pp 11-3 'a tenant might hold land for one of a variety of kinds of service. But whatever the nature of their services, all tenants had one thing in common, namely that they held their lands of a superior lord. Each one was in possession of land by virtue of 'tenure', a word derived from the latin 'tenere', meaning 'to hold'. Tenure thus connotes not merely the holding of land but also the holding of land from a superior lord, and furthermore that the land is held in return for certain services to his lord.' See also n 243.

${ }^{251}$ See also Riddall, n 244, p 27.

${ }^{252}$ Ibid.

${ }^{253}$ Ibid, p 28.
} 


\section{(c) Statute of Quia Emptores 1290}

Presently, the Statute of Quia Emptores 1290 (concerning the selling and buying of land), is obscure and archaic in language, with alternative wording. It states (as translated from the latin):

Chapter 1. Freeholders may sell their lands; so that the feoffee do hold of the Chief Lord. Forasmuch as purchasers of lands and tenements of the fees of great men and other lords, have many times heretofore entered into their fees, to the prejudice of the lords, to whom the freeholders of such great men have sold their lands and tenements to be holden in fee of their feoffors, and not of the chief lords of the fees, whereby the same chief lords have many times lost their escheats, marriages, and wardships of lands and tenements belonging to their fees; which thing seemed very hard and extreme unto those lords and other great men, and moreover in this case manifest disheritance: our the king [words omitted] at the instance of the great men of the realm, granted, provided, and ordained, that from henceforth it shall be lawful to every freeman to sell at his own pleasure his lands and tenements, or part of them; so that the feoffee shall hold the same lands or tenements of the chief lord of the same fee, by such service and customs as his feoffor held before.

Chapter 2. Sale of Part. Apportionment of Services. And if he sell any part of such lands or tenements to any, the feoffee shall immediately hold it of the chief lord, and shall be forthwith charged with the services, for so much as pertaineth, or ought to pertain to the said chief lord for the same parcel, according to the quantity of the land or tenement so sold: and so in this case the same part of the service shall remain to the lord, to be taken by the hands of the feoffee, for the which he ought to be attendant and answerable to the same chief lord, according to the quantity of the land or tenement sold, for the parcel of the service so due.

Chapter 3. Mortmain Prohibited. And it is to wit, that this Statute extendeth but only to lands holden in fee simple; and that it extendeth to the time coming [i.e. to the future]; and it shall begin to take effect at the feast of Saint Andrew the Apostle next coming. ${ }^{254}$

Thus, this Act prevents the subinfeudation of the fee simple. ${ }^{255}$ It does not prevent subinfeudation of the fee tail, albeit this is no longer an important matter today (strict strict settlements of land not being able to be created after 1996, see 9). Nor subinfeudation in the case of a grant of a life interest, as Riddall noted:

The Statute Quia Emptores [1290] referred only to subinfeudation by way of grants in fee. The Statute did not prohibit subinfeudations by way of grants of a life interest. So, even after 1290, B could have granted the land to $\mathrm{C}$ for life, to hold [of] him, B, as his feudal tenant. Whether or not this was the case depended on the circumstances of the grant. With the decline in the importance of tenure, it became rare for a life tenant to hold the land as feudal tenant of the grantor. Thus when B, the holder of a fee simple in Blackacre in the fifteenth century, granted land to $\mathrm{C}$ for life, $\mathrm{C}$ generally held the land as tenant of A. ${ }^{256}$

Thus, to modernise the law, it is asserted this legislation should be repealed ${ }^{257}$ and that modern legislation should provide something to the following effect:

Save by the Crown, the subinfeudation of land is prohibited and such shall be treated as a grant by way of substitution. ${ }^{258}$

The effect would only be to permit substitution and not subinfeudation and any attempt to achieve the former would produce the latter.

\footnotetext{
${ }^{254}$ See Halsbury, Statutes of England and Wales ('Halsbury Statutes'), vol 20. Harpum, n 241, p 28 summarised the effect of the Act as: (i) alienation by subinfeudation was prohibited (c.1); (ii) all free tenants were authorised to alienate the whole (or part) of their land by substitution, without the lord's consent, the new tenant to hold by the same services as the old (c. 2); (iii) on alienation of part of the land by substitution, the feudal services were to be apportioned (c. 2); (iv) the Statute of Quia Emptores 1290 only applied to grants in fee simple (c. 3). See also Cheshire, n 241, pp 35-6.

${ }^{255}$ Riddall, n 244, p 55 'Since 1290, alienation of the fee simple has been by substitution, not by subinfeudation.' See also Simpson, n 241, p 51.

${ }^{256} \mathrm{Ibid}, \mathrm{p} 30$. He also noted 'There is one case, however, when a person who had been granted a life estate cannot hold other than as feudal tenant of the grantor. This occurs where the grantor is the king. Thus, if the king grants Blackacre to B for life, B holds the land as feudal tenant of the Crown.'

${ }^{257}$ Harpum, n 241, p 29 'Quia Emptores 1290 is still in force today. While the wholly archaic doctrine of tenures remains, it cannot be repealed...'. This true. However, the Act can be re-stated in modern language.

258 The Crown was not bound by Quia Emptores 1290. See also Harpum, n 241, p 29.
} 


\section{In conclusion, Quia Emptores 1290 should be repealed and subinfeudation prohibited in more modern language.}

\section{MODERNISING THE LAW ON AN ENTAILED INTEREST}

(a) Introduction $^{259}$

To preserve ancestral property - that is, to try an ensure that it passed down from one generation to another - it was common for the settlor of an estate to transfer the same by way of fee tail. Such grants were (probably) introduced into England in the period 1189-1250, since Glanvill (c. 1189) makes no mention of them but Bracton does. ${ }^{260}$ The problem, pre-1285, was that a grant by A to B and 'the heirs of his body' could be frustrated since, if B had a child, B could sell the land and transfer the fee simple to the transferee. Common law judges upheld this on basis that the grant was a conditional fee which became absolute on the birth of a child. ${ }^{261}$ However, the Statute De Donis in 1285 noted:

where one gives land to another and the heirs of his body...it seemed very hard...to the givers... that their will being expressed in the gift, was not....observed...after issue [had been] born...heretofore such feoffees [i.e. B] had power to alien the land so given, and to disinherit their issue...contrary to the minds of the givers, and contrary to the form expressed in the gift.

Thus, this legislation - which was probably instigated at the behest of the nobility ${ }^{262}$ - provided that:

the will of the giver, according to the form of the deed of gift manifestly expressed, shall be from henceforth observed; so that they to whom the land was given [such as in the form of 'to B and the heirs of his body'] shall have no power to alien [i.e. alienate] the land so given, but it shall remain unto the issue of them to whom it was given after their death. ${ }^{263}$ (italics supplied)

The Statute De Donis refers to 'issue'. Such was interpreted to exclude collateral heirs as well as ancestors making the grant go to lineal descendents of the original grantee only (these are called 'heirs special'). ${ }^{264}$ The Statute also provided that - if B had no issue or, if he had, but there was no heir to succeed (i.e. in the absence of an heir) - the land would revert to the grantor (A). ${ }^{265}$

- In the grant of such an estate, the interest of B came to be called the 'fee tail' estate. Or, that B had received an estate in fee tail or in tail. ${ }^{266}$ Today, the reference is to an 'entailed interest';

- The fee tail was different to the grant of an estate for life (a life estate) since a reversion to A was - in the case of a fee tail - a possibility not (in the case of a grant of life estate) a certainty.

A grant could create a succession of fee tail estates as well as a mix of life and fee tail estates. ${ }^{267}$ In conclusion,

\footnotetext{
${ }^{259}$ See generally, Harpum, n 241, ch 3. Also, Simpson, n 241, ch 4. For older law see: (a) C Neate, Law of Entail and Settlement (1865); (b) J Dalrymple, An Essay towards a general history of Feudal Property (1757), ch 4; (c) TE Scrutton, Land in Fetters or the History and Policy of the Laws restraining the Alienation and Settlement of Land in England (1886); (d) R Chambers, A Treatise on Estates and Tenures (1824). See also, generally, Coke, n 9, vol 1 s 13 (18b) et seq on the fee tail.

${ }^{260}$ For a useful analysis of the fee tail, see W Cruise, A Digest of the Laws of England ( $4^{\text {th }}$ ed, 1835), vol 1, title 2. He noted, p 67 'These limited donations were evidently derived from the feudum talliatum...Glanville...makes no mention of limited donations; whereas...Bracton...has given a full description of them.' For Glanvill, see R Glanvill, The Treatise on the Laws and Customs of the Realm of England (c. 1189)(Nelson, 1965). For Bracton, see H Bracton (trans Thorne), On the Law and Customs of England c.1240 (Cambridge UP, 1968-76). Bracton is online, see bracton.law.harvard.edu, vol 2, p 68.

${ }^{261}$ Cruise, n 260, p 68. See also Simpson, n 241, p 64.

${ }^{262} \mathrm{Ibid}, \mathrm{p} 69$ 'the nobility, in order to perpetuate their possessions in their own families, procured the statute of Westm[inster] 2 [1285] $13 \mathrm{Edw}$ 1 usually called the statute De Donis Conditionalibus, to be made...'. Ibid, p 69 'This [legislation], as Lord Mansfield has justly observed [see Mansfield CJ in Taylor v Horde (1757) 1 Burr 115], only repeated what the law of tenures had said before, that the tenor of the grant should be observed; and therefore the judges, in the construction of it, held that where an estate was limited to a man and the heirs of his body, the donee should not in future have a conditional fee, but [they, the judges] divided the estates, by creating a particular estate in the donee, called an estate tail subject to which the reversion in fee remained in the donor.'

${ }^{263}$ See Halsbury Statutes, n 254, vol 20. See also JA Strahan, A General View of the Law of Property (6 ${ }^{\text {th }}$ ed, 1919), $\mathrm{p} 31$ who noted that the title of the Act derives from the opening words.

${ }^{264}$ Harpum, n 241, p 39 'A fee tail descended to heirs special, i.e. to lineal descendents only.' Ibid, p 49. See also Cheshire, n 241 , p 54.

${ }^{265}$ Riddall, $\mathrm{n} 244, \mathrm{p} 38$ 'If B's issue were extinct this did not necessarily mean that A would have no heir since A could have other children and they would be capable of inheriting on B's line ending. Also, A's heir could be sought among collaterals as well as his issue.'

${ }^{266} \mathrm{Ibid}, \mathrm{p} 41$ 'The word 'tail' is derived from the French 'taille', meaning 'cut down to size'. The fee tail is thus a fee, an estate of inheritance, which has been cut down by ...various restrictions on alienability.' See also Cruise, $\mathrm{n} 260$, vol 1, p 70. Jenks, n 6, p 31 'The tenant in tail is, in fact, a tenant in fee with limited powers; and it is, no doubt, a recognition of this fact which has conferred upon his estate the name of feodum talliatum or 'fee tail', i.e. a fee cut down or reduced.' See also Harpum, n 241, p 39 ; Simpson, n 241, p 64 and Chambers, n 259 , p 67.
} 
the fee tail was the grant of an estate like the fee simple. However, the tenant in tail was only a limited owner, his interest being little more than that of a life tenant and, thus, 'tailed' (from the Anglo-Norman, tailler, to cut). That is, it was cut down from a fee simple, it being subject to a condition (a conditional fee).

\section{(b) Problems with the Fee Tail ${ }^{268}$}

The problem of devolution to the lineal heir through the generations was that it tied up land without regard to whether this was actually of benefit to the holder, from time to time, of the fee tail - especially if the same was impecunious. Thus, the courts were prepared to 'bar' (break) the entail, in order to assist the same.

- Common Recovery. In 1472, by way of a collusive action of common recovery, B (the fee tail holder, or tenant in tail) could transfer the fee simple if he was: (a) a tenant in possession; or (b) the tenant in tail in remainder (reversion), where the consent of the freehold tenant in possession was given; ${ }^{269}$

- $\quad$ Fine. If the freehold tenant in possession refused to consent, B could use another form of collusive action, the fine, which had become established by 1540 . However, this resulted not in the creation of a full fee simple, but a base fee; ${ }^{270}$

- Inter Vivos Transfer. The above forms of collusive action were dispensed with by the Fines and Recoveries Act 1833. This enabled the fee tail holder to bar its entail by an inter vivos transfer of it through a disentailing assurance (which had to be enrolled within 6 months in the Court of Chancery).

${ }^{271}$ However, such could not be created by will and a base fee was also possible (see above). The Settled Land Act 1882 treated a tenant in tail in possession as a tenant for life under a settlement enabling him to lease, sell and mortgage the land without having to resort to a disentailing assurance; 272

- $\quad \underline{\text { Will}}$. The Law of Property Act 1925 enabled the fee tail to be disentailed providing this was: (a) by will (or confirmed by a codicil) after 1925; (b) the maker was of full age; (c) the maker was a tenant in tail in possession at his death; (d) the will referred to the entailed estate specifically ${ }^{273}$ (or to the maker's entailed property generally or to the instrument under which the maker acquired it). If these conditions were not met, the fee tail remained. ${ }^{274}$

All of the above was problematic and time consuming. The Trusts of Land and Appointment of Trustees Act 1996 (the ' 1996 Act') prevented the creation of entailed interests in the future. It provided for a trust, instead, for

\footnotetext{
${ }^{267}$ Riddall, n 244, p 40 gives examples. Estates in fee tail tended to be of 4 varieties: (a) an estate in tail general (e.g. to X and the heirs of his body); (b) an estate in tail male (or female) general (i.e. one qualified by sex, e.g. to X and the heirs male of his body); (c) an estate in tail special (i.e. one limited to the issue of two persons (not one) of different sexes and capable of lawful marriage, e.g. X and the heirs of his body by his wife M); (d) an estate in tail male (or female) special (same as (c) but limited to the issue of a specific sex, e.g. X and the heirs male of his body by his wife M). See Jenks, n 6, pp 31-3. For, (a) tenancy in tail after possibility of issue extinct; and (b) a tenancy in tail with reversion to the Crown, see Ibid, pp 27-8.

${ }^{268}$ See generally, Harpum, n 241, p 71 et seq. Also, Cheshire, n 241, ch 4. For a pithy summary of the fee tail see Strahan, n 263, pp 47-56.

${ }^{269}$ See Riddall, $\mathrm{n} 244$, p 41 citing Taltarum's Case (1472) YB $12 \mathrm{Edw} 4$ fo $19 \mathrm{pl} 25$. Riddall also gave an example 'if a grantor (G) granted Blackacre to $\mathrm{A}$ for life, with remainder to $\mathrm{B}$ for life, with remainder to $\mathrm{C}$ in fee tail, and $\mathrm{C}$ wished to convert his fee tail in remainder into a fee simple in remainder, he needed the consent of A (or if A was dead, that of B), in order to do so. If A and B had both died, with the result that C's fee tail had fallen into possession, he could employ the common recovery to produce a fee simple without the consent of anyone. If $\mathrm{C}$ died without barring the entail and the land passed to C's heir, D, D could similarly bar the entail by a common recovery without needing anyone's consent.' See also J Biancalana, The Fee Tail and the Common Recovery 1176-1502 (CUP, 2001) and L Bonfield, Marriage Settlements 1601-1740 (CUP, 1983). Also, Jenks, n 6, pp 34-5, Simpson, n 241, ch 6, Strahan, n 263, p 49 and Chambers, n 259, pp 79-81.

${ }^{270} \mathrm{Ibid}, \mathrm{p} 42$. The problem of the base fee was that its duration lasted only so long as the fee tail would have lasted, if it had not been barred. It was possible to enlarge the base fee into a fee simple, see Riddall, $n$ 244, $\mathrm{p} 44$. There were exceptions such as in the case of a tail special (e.g. grant to the heirs of the body begotten on a specific woman). See also Cruise, n 260, vol 1, p 70, Jenks, n 6, pp 34-6, Simpson, n 241 , p 86 and Strahan, $\mathrm{n} 263$, p 48 'if a tenant in tail alienated his estate, the grantee did not take merely a life interest: he took a base fee - that is, an estate to him and his heirs which must determine when the heirs of the body of the alienating tenant in tail [i.e. B] failed.'

${ }^{271}$ Ibid, p 43 who gave an example 'if X held Blackacre in fee tail and he wished to convey the land in fee simple to Y, X executed a disentailing assurance in Y's favour. If X wished to hold the fee simple himself, he conveyed the land to a trustee on trust for himself'. By the Law of Property Act 1925, s 72(3), X could execute the disentailing assurance in his own favour - obviating the need for a trust. See also Cruise, n 260, vol 1, ch 2; Jenks, n 6, pp 36-7, Simpson, n 241, p 256.

${ }^{272}$ Jenks, $\mathrm{n} 6$, pp 36-7 who noted (in 1899) 'with the restrictions on alienation, now...virtually removed, the difference between the powers of a tenant in tail and a tenant in fee simple may be said to end. The tenant in tail has complete powers of dealing with the land, and he cannot be prevented from committing the most arbitrary and reckless acts of destruction.' See also Strahan, n 263, p 73.

${ }^{273}$ Acheson v Russell [1951] Ch 67.

${ }^{274}$ Riddall, n 244, p 43.
} 
the person to whom the entail was granted. ${ }^{275}$ However, such did not cover entailed interests in existence at the date of the 1996 Act. $^{276}$

\section{(c) Modernising the Situation}

The situation of the entailed interest is 'limping'. That is, there still exist entailed interests governed by the complicated provisions of the old law. It is asserted that legislation should provide that all entailed interests should now be governed by the 1996 Act, in order to modernise the law and to make it much more simple and flexible. ${ }^{277}$ This would also seem to be more fair to those governed by the same. The following may be noted:

- Number of Entailed Interests. It is not known exactly how much land is subject to entailed interests today. However, their creation began to diminish from later Victorian times when it was recognised that tying up land in this way could (often) be economically unhelpful to the fee tail holder as well as the remainderman. Further, for 22 years now (i.e. since 1996), no new entailed interests can be created. And, many persons would have, in the past, broken the entail. Thus, to apply the 1996 Act might affect far fewer entailed estates than might be supposed;

- Settlor's Wishes. It may be said that applying the 1996 Act would be contrary to the settlor's wishes. However, so did any breaking of the entail. Further, doing so is (usually) in accordance with the settlor's true wishes. These would have been to tie up the estate in an economically favourable fashion (since the settlor, obviously, would have wanted to benefit both the holder of the entail and the remainderman). However, the settlor cannot see ahead into the future and - often - what he envisaged did not come about anyway. ${ }^{278}$ Thus, putting the estate into a trust means that an objective assessment can be made of the prevailing economic position as well as of the benefits to all the parties involved in the entailed estate;

- $\quad$ Lineal Issue . The entail makes descent go only to lineal issue - not to ancestors or collaterals. In hindsight - having regard to how things 'pan out' - the settlor may have preferred not to have such a restricted rule of descent.

In conclusion, it is asserted that the Statute de Donis should be repealed (as well as other legislation relating to an entailed interest) and that the 1996 Act should now apply to all existing entailed interests. This will help clarify the law, modernise matters and make things, legally, more flexible. It will also remove much old (and rather obscure) law.

\section{MODERNISING THE LAW ON STRICT SETTLEMENTS}

\section{(a) Introduction-Settled Land 279}

The entailed interest is a form of 'settlement' under the Settled Land Act 1925, section 1. However, there are other forms of settlement, which Riddall summarised with the following examples:

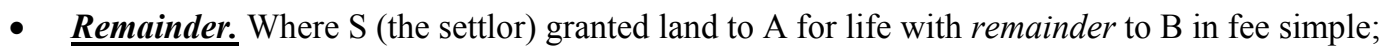

- $\quad$ Fee Tail. Where S granted land to F for an estate in fee tail;

- $\quad$ Conditional Interest. Where $\mathrm{S}$ granted land to $\mathrm{H}$ in fee simple but - if $\mathrm{H}$ died without issue - to J;

- Determinable Interest. Where $\mathrm{S}$ granted land to $\mathrm{K}$ in fee simple (or for life) until $\mathrm{K}$ committed an act of bankruptcy; ${ }^{280}$

\footnotetext{
${ }^{275}$ In a few lines Riddall summarised the story of the fee tail thus, $\mathrm{n} 244, \mathrm{p} 55$ 'The fee tail estate was one that passed to the grantee's heir found among issue only. ... On the failure of issue, the land reverted to the grantor. The grantor of a fee tail retained a fee simple in reversion...Means were devised by which a fee tail could be barred...Under the Law of Property Act 1925, a fee tail could be barred by will...No new fee tail can be created after the 1996 Act...'. For another pithy summary, see HHV Forbes, Real Property Law (1969 rep), ch 6.

${ }^{276}$ Harpum, n 241, p 47 'after 1996 it has not been possible to create an entail, though existing entails remain unaffected.' Ibid, p 50.

${ }^{277}$ The only exception, perhaps, should be entails which are unbarrable by Act of Parliament (such as those given to the first dukes of Marlborough and of Wellington and well as in respect of the Bolton estate), see Harpum, n 241, p 77, n 394. Also, Cheshire, n 241, p $604, \mathrm{n} 104$.

${ }^{278}$ Often, limited life expectancy, late age of marriage and high child mortality defeated the settlor's wishes when he settled the estate. See also Bonfield, n 269, pp 101-4. See also Scrutton, n 259, p 151 quoting Sir Francis Bacon, see J Spedding (ed), F Bacon, Works (Longmans, 1858), vol 7, 632. Scrutton's own assessment was trenchant, $\mathrm{p} 158$ 'The system of entails and settlements is therefore to be condemned both in the interests of the nation, whose development it obstructs, and in the interests of the families it is intended to preserve...'. He was in favour of abolishing entails and there is (in hindsight) much to be said for this.

${ }^{279}$ See generally, Harpum, n 241, ch 10. Also, Simpson, n 241, pp 218-24.

${ }^{280}$ Riddall noted, $\mathrm{n} 244, \mathrm{p} 123, \mathrm{n} 18$, that fee simples determinable by reason of the operation of the School Sites Act 1841-52 (see 14(b)) were not, generally, regarded as being settled land under the Settled Land Act 1925.
} 
- Contingent Interest. Where $\mathrm{S}$ granted land to the first son of $\mathrm{M}$ to be called to the Bar;

- Charged. Where S granted land to Q in fee simple but charged it with the payment of $£ 50$ pa to S's widow during her lifetime. ${ }^{281}$

Thus, the above succession of interests comprised settled land - although 'settled land' is not limited to a succession of interests. ${ }^{282}$

\section{(b) Historical Background}

Strict settlements developed during the $18^{\text {th }}$ century and they were popular in the $19^{\text {th }}$ century, with the fee tail being common. The purpose was to tie up an estate within the settlor's family for a long period of time. Riddall noted that:

It has been estimated that possibly as much as half of land in nineteenth-century England was subject to some form of strict settlement. Economic disadvantages might attach to the subjection of so much land to the fetters constituted by a settlement. In particular, the existence of the settlement might lead to under-capitalisation and the poor management of the land. For example, where land needed drainage, the life tenant would be able to carry out the work only if he could find the money out of his own pocket - perhaps from rents already at a low level. Unless the settler had conferred the power of the life tenant, capital money, if it existed, could not be used for improvements to the land. Further, unless express powers were conferred on the trustees or the life tenant, no lease for longer than the life tenant's life could be granted. But, without the certainty of being able to hold the land for a reasonable period, few tenants would be likely to manage the land with an eye to its long-term benefit, and rents from leases for the uncertain duration of a life would be lower than could be demanded for leases for a fixed period. ${ }^{283}$

The Settled Land Act 1882 conferred a power to sell settled land (in whole or part) with the beneficial interests transferring to the sale proceeds. Also, powers to lease, mortgage, exchange and improve the land ${ }^{284}$ Under this Act, the legal estate remained in the trustees, although the tenant for life (despite only having an equitable interest) was given power to sell, mortgage, lease etc. the legal fee simple. ${ }^{285}$ However, as Riddall noted:

by the time the Settled Land Act 1882 was passed, as a form of disposition of land strict settlements were falling from favour...following the industrial revolution, ownership of capital invested in industry, in commerce and in banking came to exceed in economic importance the holding of land. So men of property who wished their wealth to pass to their descendents were concerned less with settlements of land than with settlements of personalty...

another reason for the decline in the significance of settlements of land was concerned with the fiscal disadvantages, after the introduction of estate duty in 1894, attached to forms of disposition (of both land and personalty) that entailed a succession of life interests.... ${ }^{286}$ In the twentieth century settlements of land under the Settled Land Act 1925 declined in favour even where the settlement was merely in the

\footnotetext{
${ }^{281}$ Ibid, pp 122-3. See also Cheshire, n 241, pp 434-5.

${ }^{282}$ Cheshire, n 241, p 432-3 'The word settlement properly so called connotes succession. Its normal meaning is any instrument or series of instruments by which successive interests are carved out of realty and personalty and under which, in the case of land, there will usually be at any given time some person entitled in possession to a beneficial interest for life. But the Settled Land Act 1925 was not limited to cases where there was a succession properly so called. Its aim was to facilitate dealings whenever the disposition of the land was inhibited by some impediment affecting its title.... What the Act did.... with the object of rendering an absolute title easily transferable despite the existence of what would normally be inhibitory factors, was to define 'settlement' in broad terms so as to include a number of cases where there was no succession in the ordinary sense...'.

${ }^{283}$ Riddall, n 244, p 137. See also AH Manchester, A Modern Legal History of England and Wales 1750-1950 (1980), p 340 and B English and J Saville, Strict Settlement: A Guide for Historians (1983). See also Harpum, n 241, pp 394-5. For a Victorian complaint about the problems of settled land see JW Probyn (ed), Systems of Land Tenure (1876), pp 97-105.

${ }^{284}$ See Cheshire, n 241, p 102 and Re Mundy and Roper's Contract [1899] 1 Ch 275, 288. See also Simpson, n 241, pp 258-9.

${ }^{285}$ For the law on this, see Jenks, n 6, ch 25.

${ }^{286}$ Riddall, n 244, p 139 'Under the scheme of taxation introduced by the Finance Act 1894, if S settled land on A for life, with remainder to B for life, with remainder to $\mathrm{C}$ in fee simple, tax was leviable on the death not only of $\mathrm{C}$, but also on the death of the preceding life tenants, A and B. With the introduction of the principle that no estate duty was payable on the death of a spouse with a life interest, the furthest that the settler would generally wish to limit the devolution of his property would be in the form of a gift to his widow for her lifetime, with remainder to his children absolutely. In making such a grant a settlor lost the satisfaction of knowing that the land would (assuming that no advantage was taken of the Settled Land Act 1882) pass through the hands of the person he named in the settlement, but he gained the consolation of knowing that he had not saddled his descendents with a disposition that would result in the diminution (through taxation) of the value of the settled property on the death of each successive life tenant.' See also Simpson, n 241, p 222.
} 
form of a gift to a spouse for life with the remainder to the children. The principal reason was the cumbersome machinery established by the Act. If it was wished that land should go to a widow for her life, with remainder to the children, a simpler and equally effective form of disposition was to be found in the trust for sale. ${ }^{287}$ (wording divided for ease of reference)

\section{(c) 1996 Act}

The Settled Land Act 1925 went further. The legal estate was now vested in the statutory tenant for life. Further, a grant creating a succession of interests in land (a 'settlement') was governed by the Settled Land Act 1925, if not created as a trust for sale. Such strict settlements comprised the holding of the legal estate (fee simple or leasehold ${ }^{288}$ by the first person entitled to possession of the land as the statutory tenant for life ${ }^{289}$ on trust for those entitled under the settlement (including himself). The statutory tenant for life could sell the land (and exercise various other powers), with an obligation to secure the best price reasonably obtainable. The purchase price was payable to the trustees of the settlement (as appointed in the trust deed) ${ }^{290}$ with the equitable interests of those involved in the settlement being overreached and attaching to the purchase money. In the absence of a tenant for life, the legal estate was held by the trustees of the settlement. The 1996 Act provides that no settlement under the Settled Land Act 1925 can (with limited exceptions) ${ }^{291}$ be created. However, this does not affect strict settlements existing at the date of the 1996 Act, which continue to operate under the Settled Land Act 1925.

\section{(d) Modernising the Situation}

The situation of strict settlements (as with an entailed interest, one form of strict settlement, see 7) is 'limping'. Thus, for the same reasons as given above, it is asserted that legislation should provide that all strict settlements should now be governed by the 1996 Act, ${ }^{292}$ in order to modernise the law and to make it more simple and flexible. ${ }^{293}$ This process of retrospective modification is no different to that employed in the case of trusts for sale existing prior to $1996 .{ }^{294}$ They were made subject to the 1996 Act.

In conclusion, it is asserted that Settled Land Act 1925 (and all other legislation relating to strict settlements) should be repealed and that the 1996 Act should apply to all existing strict settlements. ${ }^{295}$ See Appendix A.

\section{STATUTE CONCERNING TENANTS BY THE CURTESY OF ENGLAND (pre-1285)}

\section{(a) Introduction}

The date of this Act (which does not apply to Northern Ireland) is uncertain. However, it was before 1285. Also, it is unclear whether it comprises legislation as such - as opposed to being an opinion. ${ }^{296}$ The headnote provides

\footnotetext{
${ }^{287}$ Ibid, pp 139-40. For the disaster that some forms of settlement (including entails) created, see Scrutton, n 259, ch 11, especially pp 148-9.

${ }^{288}$ As Riddall pointed out, $\mathrm{n} 244, \mathrm{p} \mathrm{135}$, a strict settlement can include a leasehold, as well as a freehold, estate.

${ }^{289}$ Riddall, n 244, p 118 'Under the machinery of the Act of 1882 the legal estate could be held by anyone whom the settler chose to name as trustee, but the Settled Land Act 1925 provided that after 1925 the legal estate had to be vested in A, as the first person entitled in possession to the land, i.e. the first person in the chain of interests. A is thus in a dual position, holding two interests: the legal estate, which he holds as a trustee; and his own beneficial, equitable, life interest. In his capacity as a trustee he is termed the [statutory] 'tenant for life' of the settlement.' ${ }^{290}$ An inter vivos settlement involved a vesting deed and a trust instrument. Ibid, Riddall, n 244, p 119, 133-4. Also, Cheshire, n 241 , p 436.

${ }^{291}$ The Settled Land Act 1925 will still apply post-1996 if (s 2) the settlement: (a) was created after the coming into operation of the 1996 Act on the occasion of an alteration in any interest in (or of a person becoming entitled under) a settlement which was in existence at the commencement of the 1996 Act; or (b) it derives from such a settlement and no provision is made in the settlement that it is not to be a settlement for the purposes of the Settled Land Act 1925. See also, Riddall, n 244, p 156, fn 3.

${ }^{292}$ For the problems of settled land outlined by the Law Commission in 1989, see Harpum, n 241, p 460.

${ }^{293}$ As Riddall noted, $\mathrm{n} 244, \mathrm{p} 157$ 'Section 6 [of the 1996 Act] provides that trustees of a trust of land have authority to exercise all the powers of an absolute owner. Thus, none of the limitations that restricted the powers of a tenant for life under the Settled Land Act 1925 (and, hence, of a trustee of a trust for sale) find a place in the 1996 Act - trustees of land can grant leases of any length, they can mortgage the land to raise money for purposes not permitted by the Settled Land Act [1925], and they can fell timber, pay for improvements out of capital and sell the principal mansion house free from the restraints that existed in the case of settlements of land before the Act. In addition to conferring on trustees all the powers of an absolute owner, the 1996 Act confers on them certain specific powers: (a) a power to purchase a legal estate in any land in the United Kingdom; and (b) a power, where the beneficiaries of full age are absolutely entitled to land subject to the trust, to partition the land and convey the partitioned land in severalty (i.e. in separate parcels) to the beneficiaries according to their interests.' See also $\mathrm{p} 168$.

${ }^{294}$ Cheshire, n 241, p 431 'The system of settlements was radically changed as from 1 January 1997, when the [1996 Act] came into operation. Thereafter no new strict settlements can be created, existing trusts of sale are retrospectively modified, and a new trust of land is invented.'

${ }^{295}$ Cf. entails unbarrable by legislation, see $\mathrm{n} 277$. Also, where the land is subject to the Universities and College Estates Act 1925, see Harpum, n 241, p 460.

${ }^{296}$ See Halsbury Statutes, n 254, vol 20. Rastell, Collections in English of the Statutes from the beginning of the Magna Carta unto 1557 now in Force (pub Wright, 1603 ed) contains a note, 'But this seemeth to be no statute, but only one man's opinion.' Given that the Statute of Westminster the Second (1285) refers to the curtesy of the second husband (see 12), the Statute concerning Tenants by the Curtesy of England
} 
'Who shall be tenant by the curtesy; who not. No homage for land given in marriage. A second husband.'

When a man shall take lands in marriage with a wife, if he have begotten of the same his wife an heir, son, or daughter, which is to be heard to cry within the four walls, if the same husband over-live his wife, whether the heir live or not, the same land shall remain to the husband [alternative wording, for his life] and after the death of the husband, the lands shall return to the donor or to his heir; but if he have no heir by his wife, then after the death of the wife, it shall return to the donor or to his heir,

And this is the cause why for land given in marriage, homage is not used to be received; for if any lands were so given in marriage or otherwise that homage were received, it might then never lawfully revert to the donor or to his heir as above is said.

And the same judgment shall be of the second husband, as is said of the first, whether there be left any heir of the first or not. (italics supplied)

(b) Explanation

As to the meaning of this Act:

- $\quad$ Tenant by the Curtesy. As Halsbury's Statutes notes, estate by the curtesy - an anomaly to the general law of descent - was the right of a husband to a life estate on his wife's death, of all her lands and hereditaments, providing he had issue by her born alive and capable of inheriting the property from her by descent; ${ }^{297}$

- Discussion of Tenant by the Curtesy. This exceptional right ${ }^{298}$ was dealt with by Littleton in his Tenures, ${ }^{299}$ by Coke in his Institutes of the Laws of England ${ }^{300}$ and by Blackstone in his Commentaries on the Laws of England. ${ }^{301}$ There have also been various cases, including Re Higham $v$ Higham (1937), ${ }^{302}$ Hope v Hope (1892) and ${ }^{303}$ Re Sirett (1968); ${ }^{304}$

- Feudal Reasons. Blackstone thought that the estate of tenant by curtesy (or by the curtesy) was introduced in England by Henry I (1100-35). He also thought there were feudal reasons for its introduction - as well as it being reasonable for the husband to have the profits of the estate to maintain it, being the natural guardian of the motherless child; ${ }^{305}$

- $\quad$ Requirements \& Exceptions. The requirements for a tenant by the curtesy were that: (a) the marriage of wife and husband had to be canonical and legal; (b) the seisin of the wife in the land had to be actual, and not just a bare right to possess; (c) the issue must be born alive; (d) the estate of tenant by curtesy was not complete (consummate) until the wife's death. ${ }^{306}$ An exception to being a tenant by curtesy

was enacted pre-1285 but exactly when, no one knows for sure. See also Chambers, n 259, p 93 (who wondered that it had not been previously noted that the 'Act' was 'merely a paragraph copied almost verbatim from Glanvill'). For the latter, see n 260.

297 Halsbury Statutes, n 254, vol 20.

${ }^{298}$ Exceptional because it overrode the feudal right of the lord, as well as that of the wife's heir. T Plunkett, Legislation of Edward I (Oxford, Clarendon Press, 1949), pp 120-1.

299 J Littleton, Tenures (c 1481, trans Wamburgh, 1903), clauses $35 \& 52$. The latter clause provides, ‘...that in every case where a man taketh a wife seised of such an estate of tenements, etc, as the issue, which he hath by his wife, [he] may by possibility inherit the same tenements of such an estate as the wife hath, as heire to the wife; in this case, after the decease of the wife, he shall have the same tenements by the curtesie of England, but otherwise not.' These clauses are discussed in Coke, n 300 below.

300 Coke, n 9, vol 1, s 35 (29a) et seq. See also Chambers, n 259, pp 92-5.

${ }^{301}$ Blackstone, n 9, vol 3, p 12. See also J Comyns, A Digest of the Laws of England (Pub. J Worrall, London, $5^{\text {th }}$ ed, 1822), vol 4, pp 55-9.

302 [1937] 2 AE 17. The intestate, at the date of her death, was a spinster of full age but unsound mind. She died in 1933, possessed of land she had acquired pre-1926, which land was subject to gavelkind. Held, by virtue of the Administration of Estates Act $1925 \mathrm{~s} 51$ (2), that her land would descend according to the general law applicable to freehold land in force pre-1926, and without gavelkind. The case of Re Price [1928] Ch 579 is also mentioned by Halsbury, but it is not on point.

${ }^{303}$ [1892] 2 Ch 336 (Estate by curtesy not affected by the Married Woman's Property Act 1882).

${ }^{304}$ [1968] 3 AE 186 (Beneficial interest of a mentally ill woman in the proceeds of sale of enfranchised copyhold land would devolve by virtue of the Administration of Estates Act 1925 s 51(2), according to the general law in force applicable to freehold land in force pre-1926). The case of Steadman v Palling (1746) 3 Atk 423 (26 ER 1044) is also mentioned by Halsbury, but it is not on point.

${ }^{305}$ Blackstone, n 9, vol 2, p 126 'I think some substantial feudal reasons may be given for its introduction. For, if a woman seised of lands hath issue by her husband and dies, the husband is the natural guardian, and as such is entitled to the profits of the lands in order to maintain it: and therefore the heir apparent of a tenant by the curtesy could not be in ward to the lord of the fee, during the life of such tenant. As soon therefore as any child was born, the father began to have a permanent interest in the lands, he became one of the pares curtis, and was called tenant by the curtesy initiate; and this estate once vested in him by the birth of the child, was not liable to be determined by the subsequent death of coming of age of the infant.' See also Simpson, n 241, p 66.

306 Ibid, pp 127-8. 
occurred when the wife was a lunatic (i.e. of unsound mind), for the Crown was entitled to such lands. 307

(c) Repeal re Deaths post 1925. The Statute concerning Tenants by the Curtesy of England was repealed by the Administration of Estates Act 1925 in respect of deaths occurring post $-1925 .{ }^{308}$ However, the same Act indicated the (new) rules of descent provided for in the Act did not apply to any beneficial interest of certain persons of unsound mind. Their estate devolved in accordance with the law, pre-1926. 309

The wording in italics in the Statute concerning Tenants by the Curtesy of England (see above text) is spent (homage no longer existing for land; it was abolished by the Tenures Abolition Act 1660). ${ }^{310}$ As for the remainder, this exception is no longer necessary - not least, since no person will fall within its ambit. Thus, the Administration of Estates Act 1925 indicates that the exception for persons of unsound mind (a lunatic, see above) can only apply (s 51(2)) to:

any beneficial interest in real estate... to which a lunatic or defective [i.e. a person of unsound mind or of low aptitude mentally] living and of full age at the commencement of this Act [i.e. 1926] and unable, by reason of his incapacity, to make a will, who thereafter dies intestate in respect of such interest without having recovered his testamentary capacity, was entitled at his death...

Thus, such a women (for the purpose of the Statute concerning Tenants by the Curtesy) of unsound mind now would have to be, at least, 113-4 years old. While she does not have to be alive, she must leave a husband alive (otherwise curtesy does not apply) and she must have had a son (or a daughter) by the husband.

- One would suggest that no person would now fall within this category and that - even if they did - the general law of intestacy is appropriate to apply in any case (as applies in Northern Ireland, where the Statute concerning tenants by the Curtesy of England does not apply); ${ }^{311}$

- If, therefore, this exception in s 51(2) is repealed, the Statute concerning tenants by the Curtesy is wholly repealed. Section 51(2) also covers 'a lunatic' (i.e. a person of unsound mind) or a 'defective' (idiot) generally. Thus, it is wider in application to a tenant by the curtesy. However, such terms are no longer used and there is no reason why such estates, also, should not descend by intestacy rules post-1926 rather than pre - not least, since the possibility of there being anyone within this category is now remote. Thus, the AEA, s 51(2) should be repealed.

In conclusion, s 51(2) - in so far as it applies to the Statute concerning tenants by the Curtesy of England (pre-1285) - should be repealed. Also, generally, so that the estates of 'lunatics' and 'defectives' on intestacy are now regulated by the law on intestacy, post-1926 and not pre.

\section{STATUTE OF WESTMINSTER THE SECOND - 1285}

After a long preamble ${ }^{312}$ this legislation has only one chapter extant. Chapter (section) 1 has a head note which

\footnotetext{
${ }^{307}$ Ibid, p 127 'If the wife be an idiot, the husband shall not be tenant by the curtesy of her lands; for the king by prerogative is entitled to them, the instant she herself has any title: and since she could never be rightfully seised of these lands, and her husband's title depends entirely upon her seisin, the husband can have no title as tenant by the curtesy.'

${ }^{308}$ Administration of Estates Act 1925 ss 54, 56, sch 2, pt 1. See Halsbury Statutes, n 254, vol 37, pp 24-5.

${ }^{309}$ Ibid, s 51(2) 'The foregoing provisions of this Part of this Act do not apply to any beneficial interest in real estate (not including chattels real) to which a lunatic [amended to refer to a person of unsound mind] or defective [idiot] living and of full age at the commencement of this Act, and unable, by reason of his incapacity, to make a will, who thereafter dies intestate in respect of such interest without having recovered his testamentary capacity, was entitled at his death and any such beneficial interest (not being an interest ceasing on his death) shall without prejudice to any will of the deceased, devolve in accordance with the general law in force before the commencement of this Act applicable to freehold land, and that law shall, notwithstanding any repeal, apply to the case.' This sub-section refers to 'his'. However, in the context of the Statute concerning Tenants by the curtesy of England, it refers to ' $h e r$ '.

${ }^{310}$ In any case this wording is explanatory only, since it merely explains why the right of the feudal lord was excluded.

${ }^{311}$ i.e. without reference to the law of curtesy. Curtesy was an exception to the general law of descent. The Administration of Estates Act 1925, s 51(2) is an also exception, preserving descent rules pre-1926. Further, the descriptions 'lunatic or defective' are no longer employed today.

${ }^{312}$ 'Whereas of late our lord the King [i.e. Edward I (1272-1307)], in the quinzim [i.e. the fifteenth] of Saint John Baptist, the sixth year of his reign [i.e. 1278], calling together the prelates, earls, barons, and his council at Gloucester, and considering that divers of his realm were disinherited, by reason that in many cases, where remedy should have been had there was none provided by him nor his predecessors, ordained certain statutes right necessary and profitable for his realm, whereby the people of England and Ireland, being subjects unto his power, have obtained more speedy justice, in their oppressions, than they had before; and certain cases, wherein the law failed, did remain undetermined, and some [alternative wording, things] remained to be enacted, that were for the reformation of the oppressions of the people: our lord the king in his Parliament, after the feast of Easter, holden the thirteenth year of his reign at Westminster [i.e.1285], caused many oppressions [of the
} 
provides 'Several sorts of gifts of lands upon condition; in such gifts the donor's will shall be observed. A fine shall not bar the heir in tail'. The first part deals with an entailed interest (see 9). The Act continues (there is alternative wording):

Neither shall the second husband of any such woman, from henceforth, have any thing in the land so given upon condition, after the death of his wife, by the law of England [i.e. by the curtesy], nor the issue of the second husband and wife shall succeed in the inheritance, but immediately after the death of the husband and wife, to whom the land was so given, it shall come to their issue, or return unto the giver, or his heir, as before is said...

And it is to wit that this statute hold place touching alienation of the land contrary to the form of the gift hereafter to be made, and shall not extend to gifts before made.

And if a fine be levied hereafter upon such lands, it shall be void in the law;

neither shall the heirs, or such as the reversion belongeth unto, though they be of full age, within England, and out of prison, need to make their claim (wording divided for ease of reference, italics supplied).

If the Stature concerning Tenants by the Curtesy of England (see 3) is wholly repealed (that is, including the exception concerning a wife of unsound mind), the wording in first paragraph of this Section should be repealed since it deals with the husband by the curtesy ('by the law of England'). The wording in the second paragraph is obsolete since it refers to the position pre-1285 ('gifts before made'). The wording in the third paragraph is spent since fines have been abolished by the Fines and Recoveries Act 1833. So too, the wording in the fourth paragraph since this is obsolete. These paragraphs also relate to an entailed interest (see 8) and, thus, should be repealed if the law on entailed interests is now governed by the 1996 Act.

\section{In conclusion, the Statute of Westminster the Seccond 1285 should be repealed.}

\section{STATUTE OF MARLBOROUGH 1267}

This legislation (also referred to as the Statute of Marlbridge) has the short title Distress Act 1267 in respect of 3 chapters and the Waste Act 1267 in respect of one. It has four chapters (sections) extant - three of which deal with the law of distress, a common law remedy. Where a tenant owes unpaid rent it accords the landlord the right to enter the premises (provided he does so peacefully) and seize chattels on the premises up to the value of that unpaid rent, until that debt is paid. ${ }^{313}$ Distress has been abolished by the Tribunals, Courts and Enforcement Act 2007 (the '2007 Act') though that Act retains a modified regime for commercial rent arrears. ${ }^{314}$ Although the 2007 Act does not expressly repeal the chapters of the Statute of Marlborough dealing with distress, it is contended that they are obsolete - either because they are no longer required or because they are contrary to the express provisions of the 2007 Act.

\section{(a) Unlawful Distress}

Chapter 1 of this bears the headnote, 'Of wrongful distresses, or Defiances of the King's Courts. Punishment for Unlawful Distresses'. After a preamble, ${ }^{315}$ it states (there is alternative wording):

it is provided, agreed, and granted, that all persons, as well as of high as of low estate, shall [alternative wording, do and] receive justice in the king's court; and none from henceforth shall take any such revenge [ultiones, revenges] $]^{316}$ or distress of his own authority, without award of our [alternative

people,] and defaults of the laws, for the accomplishment of the said Statutes of Gloucester [of 1278], to be rehearsed, and thereupon did provide certain acts, as shall appear following.' The Statutes of Gloucester have now been repealed.

313 See generally, Halsbury Laws, n 11, (4th ed), vol 13 and a useful note on distress in Halsbury Statutes, n 254, (4th ed), vol 13. See also: (a) FA Enever, History of the Law of Distress for Rent and Damage Feasant (1931); (b) J Kruse, Powers of Distress (Wildy, Simmonds \& Hill, 2009); (c) J Kruse, Bailiffs Law, A Lawful Trespass - The Development of the Common Law to the Present Day (Wildy, Simmonds \& Hill, 2009) and (d) P Brand, Kings, Barons and Justices - The Making and Enforcement of Legislation in 13 ${ }^{\text {th }}$ Century England (Cambridge, 2000$)$, ch 14.

314 Tribunals, Courts and Enforcement Act 2007, s 71, 'The common law right to distrain for arrears of rent is abolished.'

315 'Whereas at the time of a commotion late stirred up within this realm, and also sithence [i.e. since that time] many great men, and divers other, refusing to be justified [alternative version, have disdained to be justised [i.e. judged]] by the king and his court, like as they ought and were wont in time of the king's noble progenitors, and also in his time; but took great revenges and distresses of their neighbours, and of other, until they had amends and fines at their own pleasure; and further, some of them would not be justified [alternative wording, will not be justized [i.e. judged]] by the king's officers, nor would [alternative version, will] suffer them to make delivery of such distresses as they had taken of their own authority [alternative version, at their own pleasure]...' For this troubled period in the reign of Henry III (1216-72) see Oxford Dictionary of National Biography (DNB), Oxford University Press (2004) (DNB). Also, Brand, n 313.

316 The latin says 'ultiones' which suggests the idea of taking private redress. CT Lewis \& C Short, A Latin Dictionary (1890)(ultio) 'a taking vengeance, avenging, revenge'. More specifically, the word may include reference to the practice of 'withernam' (an Anglo-Saxon word, 
wording, the king's] court, though he have damage or injury, whereby he would have amends of his neighbour, either higher or lower.

And upon the aforesaid article it is provided and granted, that if any from henceforth take such revenges of his own authority, without award of the king's court as before is said, and be convict thereof, he shall be punished by fine, ${ }^{317}$ and that according to the trespass; and likewise if one neighbour take a distress of another without award of the king's court, whereby he hath damage, he shall be punished in the same wise, and that after the quantity of the trespass; and nevertheless sufficient and full amends shall be made to them that have sustained loss by such distresses (wording divided out, for ease of reference).

Halsbury (Laws and Statutes) refers to no caselaw, and such as there is, is generally old. ${ }^{318}$ It is asserted this chapter is spent for the following reasons:

- The 2007 Act abolishes the common law right to distress - save in the case of commercial rent arrears. Under that Act, only an enforcement officer may take control of distressed goods and sell them pursuant to a designated enforcement procedure. ${ }^{319}$ Thus, private distress (including withernam) is prohibited. As a result, the 2007 Act supercedes the Statute of Marlborough in this respect;

- The 2007 Act lays down a detailed procedure in respect of distress for commercial rent arrears - the remedy for the non-observance of which lies in the return of the goods and the payment of damages, if so ordered by a court. ${ }^{320}$ Thus, the remedy is a civil - and not a criminal - one. As a result, the 2007 Act supercedes the Statute of Marlborough in this respect.

Halsbury's Statutes (volume 20) quotes the Law Commission in their Statute Law Repeals: Nineteenth Report (Law Com no 333)(April 2012):

In our consultation paper (SLR 03/14) we indicated that, notwithstanding the enactment by Parliament of the Tribunals, Courts and Enforcement Act 2007, the breadth of the 2007 Act is insufficient to render chapter 1 of the Statute of Marlborough [1267] unnecessary. The 2007 Act, in Part 3, provides a new code for the recovery of debt in place of an individual's right to distrain on a debtor's goods (and abolishes the common law rules relating to replevin and restraint for rent arrears). However, chapter 1 of the Statute criminalised the taking of 'revenges' or the levying of distress without first obtaining a court order. By contrast the 2007 Act criminalises only the procedural aspects (acting as an enforcement agent without authority) rather than the substantive behaviour of the actor (the taking of distress unlawfully). On that basis we considered that chapter 1 was not spent. ${ }^{321}$ (italics supplied)

With respect to the Law Commission, the analysis of their Statute Repeals Department on this matter would seem incorrect.

- Parliament would hardly have called this chapter of the legislation the 'Distress Act' - nor would the headnote have referred to 'wrongful distresses' - if this chapter was intended to assert a wide, general, legal proposition that only the king's courts could be resorted to in respect of any redress (whether criminal or civil) as opposed to taking (private) revenge. Further, this chapter must be construed with regard to the other chapters of this Act, such as those referred to below, which dealt with distress;

referring to taking the goods of the other in return by way of redress). J Whishaw, A New Law Dictionary (1829)(withernam) (from the Sax. Wither, i.e. altera, or as some say, contra, and nam, captio)...It is a taking or reprisal of other cattle or goods in lieu of those that were formerly unjustly taken and eloined, or otherwise withholden'). See also Statute of Westminster the Second 1285, s 2.

${ }^{317}$ The latin says 'redemptionem' which would (it seems) be better translated as 'compensation' - suggesting a civil, rather than a criminal, offence. See Lewis \& Short, n 316 (redemptio) 'a buying back, buying off...'.

${ }^{318}$ See Kruse, n 313 (see (c)), ch 6 and Brand, n 313. For the idea that this chapter supports a much wider proposition, prohibiting private revenge generally, see Coke, $\mathrm{n}$ 9, vol 2, pp 102-3. However, his authority for such a wide interpretation is slim. In this context, chapter 4 has long been limited to the law of distress. e.g. C Viner, Abridgment ( $1^{\text {st }}$ ed, 1753), vol 9. Also, D Barrington, Observations upon the Statutes (W Bowyer, London, $5^{\text {th }}$ ed, 1796), p 42, 'The first chapter relates to distress, which were most oppressively used. If complaint were made of this oppression, the barons insisted upon determining the complaint against their own officers in their own courts [i.e. courts baron and leet], and would not permit the king's courts to hold conusance.' See also earlier editions of Halsbury's Statutes, The Statutes Revised (HMSO, $3^{\text {rd }}$ ed, 1950) and Chitty's Statutes of Practical Utility (16 ${ }^{\text {th }}$ ed, 1912). Also Potts v Hickman [1941] AC 212, 241 (per Lord Wright). Also, Brand, $n$ 313, pp 192-3 \& 367-9 and P Walton, Landlord's Distress - Past its Sell By Date. Conv (2000) Nov/Dec 508-27.

${ }^{319}$ Tribunals, Courts and Enforcement Act 2007, sch 12, part 1, para 2(2).

${ }^{320}$ Ibid, sch 12, part 2, para 66.

321 The reference to 'criminalises' clearly suggest that the Law Commission think that chapter 1 is a criminal offence. However, 'redemptionem' does not suggest this. It suggests compensation rather than a criminal fine (see n 317). 
- This chapter must also be considered in its historical context - the situation where the barons were using their courts (courts baron and, possibly, leet) to deal with distress 'without award of the king's court'. In other words, the Crown was re-asserting the jurisdiction of the king's courts in a troubled historical period in which the sovereign was suffering a considerable challenge to his authority at the hands of his barons where they were asserting the jurisdiction of their own local courts. It may be noted - in this respect - that (likely) distress (a civil matter) would have been within the jurisdiction of such local courts at the time of the Norman Conquest (1066)). Further, chapter 2 of this Statute of Marlborough (rep) sought to prevent the barons taking distresses by compelling persons to appear before their courts if that person was not a suitor in that court. ${ }^{322}$ Thus, chapters 1 and 2 must be construed together and both relate only to the law on distress. In any case, courts baron and courts leet no longer operate since $1977 .^{323}$ Thus, this particular scenario will no longer arise.

Even if the above analysis is incorrect, it would seem that Parliament - by authorising the title the 'Distress Act' (see Statute Law Revision Act 1948) to apply to chapter 1 of the Statute of Marlborough, intended to so limit the extent of the same in modern times. As it is - given that common law distress has been abolished by the 2007 Act - any mention of 'distress' in chapter 1 should also be repealed, today. Such would leave only chapter 1 with only the following wording:

it is provided, agreed, and granted, that all persons, as well as of high as of low estate, shall receive justice in the king's court; and none from henceforth shall take any such revenge ... of his own authority, without award of our court, though he have damage or injury, whereby he would have amends of his neighbour, either higher or lower...

and upon the aforesaid article it is provided and granted, that if any from henceforth take such revenges of his own authority, without award of the king's court as before is said, and be convict thereof, he shall be punished by fine, and that according to the trespass;

Such remaining wording would appear to mean that - if a person takes any other 'revenges' for any 'damage or injury' without making an application to the king's court for redress - he is liable to pay compensation (redemptionem), this sum being calculated with regard to the 'trespass.'

- Would this be limited only to civil matters? Yet, if civil, there are many tribunals (and arbitration systems) today for dispute resolution unconnected with the king's courts. Does this mean that a person resorting to them has committed a civil offence pursuant to chapter 1 ?

- Further, the latin word 'redemptionem' in chapter 1 suggests a civil penalty (although in early medieval times the precise demarcation between civil and criminal offences was not clear), something the Law Commission (see the quotation above) appear not to have accepted. Yet if a criminal offence, how might the compensation be calculated ? And, what process might be employed to summon a defaulter to court etc.? Further, why has there never been a case (it seems) on this crime for more than 650 years (this crime would - if such it is - be the oldest on the Statute book)?

- It also seems that the Law Commission - in light of their quotation above - was seeking to limit chapter 1 to the making of a private (unlawful) distress and not construing it with regard to any other matter. However, if so, would not the drafters of the 2007 Act have inserted chapter 1 as so construed in the 2007 Act, if they had thought it necessary ? Or, is the Law Commission (seriously) suggesting that the drafters overlooked the Statute of Marlborough 1267, chapter 1 ? One would suggest, rather, that they regarded it as obsolete.

In conclusion, this chapter (section) 1 relates only to distress. And, it should be repealed in light of the 2007 Act (or, if really necessary, the 2007 Act should be amended to cover it).

\section{(b) Distresses to be Reasonable etc and Place for Distress}

\footnotetext{
${ }^{322}$ Chapter 2 (rep, none but suitors shall be distrained to come to a court) 'Moreover, none (of what estate soever he be) shall distrain any to come to his court, which is not of his fee (fief), or upon whom he has no jurisdiction, by reason of hundred, or bailiwick; nor shall take distresses out of the fee or place where he has bailiwick or jurisdiction; and he that offends against this Statute shall be punished in like manner, and that according to the quantity and quality of the trespass.' See also chapter 3 (rep, a lord shall not pay a fine for distraining his tenant). This chapter (clearly, it seems) refers to distress in the context of chapter 1 since it states: 'If any, of what estate soever he be, will not suffer such distress as he has taken, to be delivered by the king's officers, after the law and custom of the realm, or will not suffer summons, attachments, or executions of judgments given in the king's court, to be done according to the law and custom of the realm, as is aforesaid, he shall be punished in the manner aforesaid, as one that will not obey the law...' (italics supplied).

${ }^{323}$ See McBain, n 121.
} 
Chapter (section) 4 has a headnote which is entitled, 'Distresses shall not be driven out of the country. Distresses shall be reasonable'. It states (there is alternative wording) that:

None from henceforth shall cause any distress that he hath taken, to be driven out of the county, where it was taken; and if one neighbour do so to another of his own authority, and without judgment, he shall make fine, as above is said, as for a thing done against the peace; nevertheless, if the lord presume so to do against his tenant, he shall be grievously punished by amerciament. ${ }^{324}$ Moreover, distresses shall be reasonable, and not too great; and he that taketh great [alternative wording, undue] and unreasonable distresses, shall be grievously amerced for the excess of such distresses (italics supplied).

Thus, goods subject to distress may not generally be removed from one county to another 'without judgment' (i.e. by way of private distress). If so, criminal sanctions (i.e. a fine or amerciament) shall be imposed. Also, distresses must be reasonable (not excessive). As Halsbury's Statutes notes, ${ }^{325}$ the removal of distress was regulated by the Distress Act 1554 (rep). However, this was rarely resorted to in modern practice - both parties finding it more convenient to having the goods impounded on the premises - as authorised by the Distress for Rent Act 1737, s 10 (repealed). It is contended that this chapter 4 of the Statute of Marlborough is spent for the following reasons:

- Reference is made to the word 'driven', indicating that it principally related to distress of animals. Distress damage feasant at common law (e.g. distress over stray beasts trespassing) was abolished by the Animals Act 1971 which substituted a statutory regime. Thus, chapter 4 no longer covers them; ${ }^{326}$

- The 2007 Act abolishes the common law right to distress - save in the case of commercial rent arrears. Under that Act only an enforcement officer may take control of distressed goods and sell them pursuant to a designated enforcement procedure. Thus, private distress is prohibited. Further, the Act lays down a detailed procedure - the remedy for the non-observance of which lies in the return of the goods and the payment of civil damages, if so ordered by a court and not by way of a fine or amerciament. More particularly, the Act also provides where distress may be effected ${ }^{327}$ and the amount of distress that may be levied - which latter goes to the question of reasonableness. ${ }^{328}$

Halsbury (Statutes or Laws) cites no caselaw in respect of this chapter 4, and that which there is, is generally old. ${ }^{329}$ It is asserted this chapter is no longer required. It is covered by the 2007 Act. Finally, chapter (section) 15 of this Act has a headnote entitled, 'In what places distresses shall not be taken'. It states (there is alternative wording):

It shall be lawful for no man from henceforth, for any manner of cause, to take distresses out of his fee [this is, his fief - being land over which he has jurisdiction], nor in the king's highway, nor in the common street, but only to the king or his officers, [having special authority to do the same]. ${ }^{330}$

Thus, generally, distress cannot be levied in the common highway or street. As Halsbury's Statutes notes, the common law admitted one exception to this. Cattle deliberately driven off the premises in order to avoid seizure could be taken in immediate pursuit. ${ }^{331}$ Further exceptions were contained in the Rent Act 1737 (repealed). ${ }^{332}$ It is contended that this chapter no longer applies since the 2007 Act provides that distress - in the case of

\footnotetext{
${ }^{324}$ PM Walker, Oxford Companion to the Law (Oxford, 1980), 'Amerciament or amercement. In English law a pecuniary penalty for an offence, where the offender was brought before the courts of his lord, whether king or subject-superior, and was at the mercy of the lord.' See also Brand, n 313, p 194. For the re-enactment of chapter 4 in the Statute of Westminster I (1275), ch 16, see Coke, n 9, vol 2, p 191.

${ }^{325}$ Halsbury Statutes, n 254, vol 20.

326 Animals Act 1971, s 7(1), 'The right to seize and detain any animal by way of distress damage feasant is hereby abolished.'

327 Tribunals and Courts Act 2007, sch 12, part 2 paras $9 \& 31$ (highway).

${ }^{328}$ Ibid, para 12. An enforcement officer may not take control of goods whose aggregate value is more than: (a) the amount outstanding; and (b) an amount in respect of future costs, calculated in accordance with regulations. Cf. J Kruse, Taking Limited Control SJ (2007) 151 (32) 1088-9, 'In respect of the Statute of Marlborough [1297] it can be objected that only the common law rules on excessive seizures are respected; the statutory remedy plainly survives.' It is asserted that the statutory remedy under this Act is unnecessary in light of the 2007 Act.

${ }^{329}$ Many of the cases relating to 'excessive distress' are under the common law or the Statute of the Exchequer c. 1322 (now repealed). See Blackstone, n 9, vol 3, p 12 and Brand, n 313, ch 14. Kruse, n 313 (see (c)), p 154, says the Statute of Marlborough 1267 has survived the 2007 Act but is 'of very limited practical use' See also Steel Linings Ltd v Bibby [1993] RA 27 and Bhatnagar \& Elanrent v Whitehall Investments (1995) Current Law Digest May, p 61.

${ }^{330}$ Halsbury Statutes, $\mathrm{n} 254$, vol 20 notes that the wording in brackets was inserted in the text of the statute from the Close Roll. See also Brand, n 313, pp 95, 125, 189, 369-77, 403, 421.

${ }^{331}$ See Halsbury Statutes, n 254, vol 13, p 1291. Also, Coke, n 9, vol 1, s 161a. Seizures of animals under the Animals Act 1971 will exclusively occur on the distrainor's own property. See Kruse, n 313, pp 12-4, 178.

${ }^{332}$ Sections 1 and 8 (repealed).
} 
commercial rent arrears - can be effected in the highway. ${ }^{333}$

In conclusion, these chapters (sections) relate to distress and they should be repealed in light of the 2007 Act.

\section{(c) Waste}

The only other extant chapter (section) of Statute of Marlborough 1267 (there is also a preamble to this statute, which is no longer relevant) ${ }^{334}$ is chapter (section) 23 which has the short title, the 'Waste Act 1267'. Chapter 23 makes provision on fermors (farmers) 335 making no waste, stating (there is alternative wording):

fermors, during their terms, shall not make waste, sale, nor exile of house [alternative wording, houses] woods, and men, nor of any thing belonging to the tenements that they have to ferm, without special licence ${ }^{336}$ had by writing of covenant, making mention that they may do it; which thing if they do, and thereof be convict, they shall yield full damage, and they shall be punished by amerciament grievously.

In the reign of Henry III (1216-72) chaos prevailed through the land and many legal rights were ignored. This was particularly so in 1267 , when Henry III was emerging from his civil war with Simon de Montfort. ${ }^{337}$ The Statute of Marlborough 1267 was intended to redress this.

- The provision on waste was designed to punish tenants who returned the land in a neglected state (i.e. where they failed to keep the premises in repair). It imposed a criminal sanction on those who did viz. amerciament (a fine); ${ }^{338}$

- Today, the reference to 'men' in the chapter is obsolete. ${ }^{339}$ 'Exile of house' likely refers to any neglect of any building. ${ }^{340}$

It is contended this chapter is no longer required. Any sale or alienation of real estate - or waste - by a tenant gives rise to civil remedies today, not to criminal ones. These remedies now lie in contract, tort and equity. Thus, in the case of waste, ${ }^{341}$ an injunction can be granted where either voluntary or equitable waste is threatened or apprehended. ${ }^{342}$ And, where waste has been committed, an equitable lien lies against the tenant for life against the profits receivable by him during the remainder of his life. ${ }^{343}$ The obligation not to commit waste is an obligation in tort and equitable waste is a breach of trust. ${ }^{344}$ There would not appear to have been much caselaw on chapter 23 of the Statute of Marlborough 1267 and it is not discussed in Halsbury (whether Statutes or Laws). ${ }^{345}$ Amerciament by a court (a criminal penalty) is no longer appropriate, or required, in the case of

\footnotetext{
333 Tribunals, Courts and Enforcement Act 2007, sch 12, part 2 paras 9 (highway), 13 (ways of taking control) \& 31 (highway).

${ }^{334}$ It provides 'In [1267] the two and fiftieth year of the reign of King Henry [1216-72], son of King John [1199-1216] , in the utas [festival period] of Saint Martin, the said King our Lord providing for the better estate of his realm in England, and for the more speedy administration of justice, as belongeth to the office of a King, the more discreet men of the realm being called together, as well as of the higher as of the lower estate: [It was provided, agreed and ordained, that whereas the realm of England of late hath been disquieted with manifold troubles and dissentions, for reformation whereof statutes and laws be right necessary, whereby the peace and tranquillity of the people must be observed; wherein the King, intending to devise convenient remedy, hath made these acts, ordinances, and statutes underwritten, which he willeth to be observed firmly and inviolably for all of his subjects, as well high as low.] There is an alternative translation, see Halsbury Statutes, $\mathrm{n} 254$, vol 20 .

${ }^{335}$ Woodhouse v Walker (1880) 5 QBD 494 per Lush J, at p 406, 'The term 'fermors' here, says Coke, 2 Instit 145, [see n 9, vol 2, s 145] comprehended all who held by lease for life or lives, or for years by deed or without deed, and the words 'do or make waste' in legal understanding in this place...includes as well permissive waste which is waste by reason of omission or not doing, as for want of reparation, as waste by reason of commission [i.e. voluntary waste], as to cut down timber, trees or prostrate houses and the like: for he that suffereth a house to decay which he ought to repair doeth the waste. The 'special licence' mentioned in the Statute of Marlbridge is commonly expressed by the well-known phrase 'without impeachment of waste.' See also Brand, n 313, pp 345-7.

${ }^{336}$ For the meaning of this expression, see n 335 above.

337 See n 315.

338 Walker, n 324. Cf. Dayani v Bromley LBC (No 1) [1999] 3 EGLR 144 where Judge Harvey QC considered that a civil remedy was provided (although he accepted the Statute of Gloucester 1278 c 5 and the Statute of Westminster 2 (1285) c 14 also provided a civil remedy). He considered that the Statute of Marlborough [1267] was the basis for asserting that 'a tenant for life and a tenant for years were liable in damages for permissive waste for about 600 years from 1267.' (italics supplied)

339 In early medieval times, villeinage (serfdom) still existed. See P Vinogradoff, Villeinage in England (Oxford, 1892).

340 The Oxford English Dictionary notes in respect of the definition of 'exile' that, in Old French, the verb had chiefly the sense of 'to ravage, devastate'. Thus, it would seem to refer to voluntary (i.e. wilful) waste, see Halsbury Statutes, n 254, vol 42, para 987.

341 See Halsbury Laws, $n 11,\left(4^{\text {th }}\right.$ ed $)$, vol 42, paras 986-1001.

342 Ibid, vol 16 para 777 (equity), vol 24 paras 890-2 (injunction) and vol 42, para 1001.

343 Ibid, vol 42, para 1001.

344 Ibid, vol 27(1), para 345 and vol 16, para 777.

${ }^{345}$ In Woodhouse v Walker (1880) 5 QBD 494, the defaulting tenant had died, avoiding any criminal prosecution.
} 
waste. It is contended this chapter 23 is now obsolete.

\section{In conclusion, the Statute of Marlborough 1267 should be wholly repealed.}

\section{OTHER LEGISLATION}

There are other pieces of legislation pre-1925 relating to land which are extant but which (it is asserted) are no longer required and can be repealed or consolidated. As to these:

\section{(a) Literary and Scientific Institutions Act 1854}

In mid-Victorian times there was a movement for the advancement of learning and the encouragement of the Arts. The above Act enabled persons to provide land for the same. Section 1 states:

Any person in England, Wales, or Ireland, being seised in fee simple, fee tail, or for life,...in any...lands... and having the present beneficial interest therein, may grant, convey ...by way of gift, sale, or exchange, in fee simple or for a term of years, any quantity not exceeding one acre of such land, whether built upon or not, as a site for any such institution as hereinafter described: provided, that no such grant made by any person seised only for life of and in any such...lands shall be valid, unless, if there be any person next entitled to the same in remainder, in fee simple or fee tail, and if such person be legally competent, he shall be a party to and join in such grant...

Such sites were for institutes as described in section $33 .{ }^{346}$ It should be noted that this Act was used by lords of the manor to make grants from manorial waste in the past. ${ }^{347}$ However, today, there is no need to rely on such legislation to gift land for charitable purposes. It is asserted that this Act should be repealed, with the Reverter of Sites Act 1987 applying to the reversion of any land so granted (cf. section 4 of the Literary and Scientific Institutions Act 1854). ${ }^{348}$

\section{In conclusion, the 1854 Act should be repealed and all literary and scientific institutions presently subject to it should be subject to the Reverter of Sites Act 1987.}

\section{(b) School Sites Act 1841}

Similar to the Literary and Scientific Institutions Act 1845 which followed it, the School Sites provided for the use of land for poor schools. Thus, section 2 (landlords empowered to convey land to be used as sites for schools etc) states:

Any person, being seised in fee simple, fee tail, or for life, of and in any manor or lands of freehold, copyhold, or customary tenure, and having the beneficial interest...may grant, convey, or enfranchise by way of gift, sale, or exchange, in fee simple or for a term of years, any quantity not exceeding one acre of such land, as a site for a school for the education of poor persons, or for the residence of the schoolmaster or schoolmistress, or otherwise for the purposes of the education of such poor persons in religious and useful knowledge;

provided that no such grant made by any person seised only for life of and in any such manor or lands shall be valid, unless the person next entitled to the same in remainder, in fee simple or fee tail, (if legally competent) shall be a party to and join in such grant:

provided also, that upon the said land so granted as aforesaid, or any part thereof, ceasing to be used for the purposes in this Act mentioned, the same shall thereupon immediately revert to and become a portion of the said estate held in fee simple or otherwise, or of any manor or land as aforesaid, as fully to all

\footnotetext{
${ }^{346}$ Section 33 (to what institutions the Act shall apply). The Act shall apply to every institution for the time being established for the promotion of science, literature, the fine arts, for adult instruction, the diffusion of useful knowledge, the foundation or maintenance of libraries or reading rooms for general use among the members or open to the public, of public museums and galleries of paintings and other works of art, collections of natural history, mechanical and philosophical inventions, instruments, or designs; provided, that the Royal Institution...shall be exempt from the operation of this Act. '

${ }^{347}$ Eversley, n 12, p 201 noted that the Commons Act 1899 restricted 'the power of the lord of the manor to make grants of wastes under a number of old statutes' citing, inter alia, the Literary and Scientific Institutions Act 1854.

${ }^{348}$ Ibid, s 4 (if lands cease to be used for the purposes of the Act they shall revert). 'Provided, that upon any land so granted by way of gift as aforesaid, or any part thereof, ceasing to be used for the purposes of the institution, the same shall thereupon immediately revert to and become again a portion of the estate or manor or possessions of the Duchy, as the case may be to all intents and purposes as fully as if this Act or any such grant as aforesaid had not been passed or made, except that where the institution shall be removed to another site the land not originally part of the possessions of either of the Duchies aforesaid may be exchanged or sold for the benefit of the said institution, and the money received for equality of exchange or on the sale may be applied towards the erection or establishment of the institution upon the new site.' The references are to the duchies of Lancaster and Cornwall. See also Halsbury Statutes, n 254, vol 21 (general note to Act).
} 
intents and purposes as if this Act had not been passed, any thing herein contained to the contrary notwithstanding. ${ }^{349}$ (italics supplied)

This Act was supplemented by the School Sites Acts 1844, 1849, 1851 and 1852. This Act is now obsolete and persons do not generally grant:

by way of gift, sale, or exchange, in fee simple or for a term of years, any quantity not exceeding one acre of such land, as a site for a school for the education of poor persons, or for the residence of the schoolmaster or schoolmistress, or otherwise for the purposes of the education of such poor persons in religious and useful knowledge (italics supplied)

Or, if they do, they do not do so relying upon this Act (and they grant more than 1 acre). Further, the effect of such a grant (if made by gift) is to extinguish, ipso facto, rights of common in any waste or commonable land, which would not seem appropriate today. It is asserted these Acts should be repealed as spent, with the Reverter of Sites Act 1987 applying.

In conclusion, the School Sites Acts should be repealed and all schools presently subject to it should be subject to the Reverter of Sites Act 1987.

\section{(c) Convevancing Act 1881, Land Settlement (Facilities Act) Act 1919, Law of Propertv Act 1922}

The Conveyancing Act 1881 only contains sections $2 \& 72{ }^{350}$ the Land Settlement (Facilities) Act 1919 only sections 2, 8-25, $28{ }^{351}$ and the Law of Property Act 1922 only sections 43, 137, 144 \& 144A, 145. ${ }^{352}$ These sections can be inserted into a new Open Spaces Act or they are otherwise spent. The Law of Property (Amendment) Act 1924 is spent.

\section{In conclusion, the above legislation should be repealed.}

\section{UNREGISTERED LAND}

If all the matters referred to in this article are repealed, then all legislation relating to land should be consolidated into an OSA, a Land Act and a Landlord and Tenant Act (see Appendices A- C). This would (hugely) help all lawyers specialising in land law as well as commerce and industry in general. As to remaining unregistered land in England and Wales (see 1), it is asserted that the process of registration should be expedited since such brings enormous benefits.

- Not only is registered land more user friendly to deal with than that subject to older law, registration helps identify who owns land. This includes where such land has no owner as well as when land is owned by criminals. Thus, registration helps local councils identify (and deal with) derelict land and it helps Government organisations and departments dealing with asset seizures, to seize land owned by criminals;

- Further, there is a public policy interest in the State - and the general public - having a modern, transparent system of land ownership. One less costly in terms of the legal process and where titles and rights to land can be determined more easily. Registration will also help identify manorial waste and other common land.

Thus, provision should be made for all persons with unregistered land to, now, have a compulsory obligation imposed by law to register the same, say, before 1925 - with a penalty imposed for failing to do so (possibly, an increased stamp duty). Conveyancing lawyers are, also, likely to welcome this since they make their money, nowadays, by way of throughput and the older law can be a trap for the unwary, including them.

In conclusion, all present unregistered land should be registered by 2025, with a penalty imposed for failing to do so.

\section{OVERALL CONCLUSION}

\footnotetext{
${ }^{349}$ See also Scriven, n 10, p 331. See also Jessel Manor, n 12, pp 318-20 referring to Marchant v Onslow [1994] 13 EG 114.

${ }^{350}$ Section 2 contains definitions which (if still required) should be placed in a new Land Act. Section 72 relates to Northern Ireland and is spent.

${ }^{351}$ Sections 2 and 9-25 relate to allotments, s 28 to commons and open spaces. These should be inserted into an Open Spaces Act (see Appendix B).

${ }^{352}$ Section 43 relates to settled land (re glebe), section 137 to royal parks, sections 144 \& 144A to manorial court rolls and section 145 to the conversion of perpetually renewable leaseholds. Section 43 should be repealed as with other provisions on settled land (see Appendix A), s 137 inserted into an Open Spaces Act (see Appendix B), ss 144 \& 144A inserted into a new Open Spaces Act and s 145, into a new Landlord and Tenant Act.
} 
It is very important that our land is modern and up to date. This article asserts, therefore, the following:

- Inclosure Acts 1773-1868. All inclosure Acts (general, local and private) should be repealed. There are no more open fields in England and Wales (bar Laxton in Nottinghamshire). Further, the 1733 Act was intended to be superceded by the 1845 Act (as amended) which, itself, was intended to be superceded by the Commons Act 1876 which latter Act adopted a different policy and process as to the inclosure of land;

- Subinfeudation. Quia Emptores 1290 (prohibiting fee simple subinfeudation) should be repealed and a prohibition on subinfeudation couched in more modern language. It may be noted that this legislation would not be required if the feudal system of land tenure is abolished (this will be dealt with in a subsequent article);

- Tenants by the Curtesy. The Statute concerning Tenants by the Curtesy of England (pre-1285) (dealing with estates of women of unsound mind pre-1926) should be repealed, as well as the Administration of Estates Act 1925, s 51(2) so that all estates of persons who are of unsound mind ('lunatics') and those with low mental aptitude ('defectives as the 1925 describes them) are governed by the law on intestacy post-1926 and not before. In any case, it is highly unlikely that any such persons (or the husband, in the case of a tenant by the curtesy) are still living;

- Entailed Interests. The Statute de Donis Conditionalibus 1285 (dealing with grants of entailed interests) and the Settled Land Act 1925 (dealing with settled land), as well as connected legislation, should be repealed. All settlements still existing (including any entailed interest) should now be governed by the Trusts of Land and Appointment of Trustees Act 1996;

- Waste \& Distress. The Statute of Marlborough 1267 (dealing with waste and distress) should be repealed. It is no longer required;

- Other Obsolete Legislation. The Literary and Scientific Institutions Act 1854 and the School Sites Acts 1841-52 should be repealed, being no longer required. So too, the Conveyancing Act 1881, Land Settlement (Facilities) Act 1919, the Law of Property Act 1922 and the Law of Property Amendment Act 1924 (with certain sections of the same being placed in an Open Spaces Act (OSA), see Appendix C);

- Legislation relating to Military \& Crown Land. Victorian legislation relating to military land should be modernised and placed in a new Armed Forces Act. Legislation on Crown land (see Appendix B (f) should be modernised and placed in a Crown Act, together with legislation on the Crown Estate;

- Open Spaces Act. If the above is effected, all legislation extant relating to: (a) parks and recreation grounds; (b) London open spaces; (c) town gardens and squares; (d) royal parks; (e) royal botanic gardens; (f) national parks; (g) town and village greens; (h) recreation grounds; (i) metropolitan commons; (j) allotments; (k) roadside waste; (l) common land; (m) Dartmoor, Forest of Dean, New Forest, Epping Forest, should be placed in an OSA, with the provisions on each being made more consistent;

- Endgame. All land legislation should be consolidated into a: (i) Land Act; (ii) Landlord and Tenant Act; and (iii) an OSA. This would not be difficult if the material referred to in Appendix $\mathbf{A}$ is repealed, as described.

\section{APPENDIX A - LAND REFORM ACT}

\section{Inclosure Acts 1733-1868}

(a) The following are repealed, without prejudice to any award made thereunder, the: (i) Inclosure Act 1773; (ii) Inclosure (and Drainage) Act 1833; (iii) Lands Consolidation Act, sections 99-107; (iv) Inclosure Act 1845; (v) Inclosure Act 1846; (vi) Inclosure Act 1847; (vii) Inclosure Act 1848; (viii) Inclosure Act 1849; (ix) Inclosure Act 1854; (x) Inclosure Act 1857; (xi) Inclosure Act 1859; (xii) Inclosure etc and Expenses Act 1868;

(b) The following [4000] private and local inclosure Acts are repealed [ ]. ${ }^{353}$

\footnotetext{
${ }^{353}$ There may be 4,000 or more of these Acts. This is something for the Law Commission, Statute (Repeals) Department to deal with.
} 


\section{Subinfeudation ${ }^{354}$}

(a) Save by the Crown, the subinfeudation of land is prohibited and such a grant shall be treated as a grant by way of substitution; ${ }^{355}$

(b) The Statute of Quia Emptores 1290 is repealed.

\section{Settled Land}

(a) The Trusts of Land and Appointment of Trustees Act 1996 shall apply to all settled land (as defined in the Settled Land Act 1925), save where legislation prohibits dis-entailment; ${ }^{356}$

(b) The following are repealed: (i) Statute de Donis Condicionalibus 1285; (ii) Statute of Westminster 1285; (iii) Settled Land Act 1882; (iv) Settled Land Act 1889; (v) Settled Land Act 1890; (vi) Settled Land Act 1925; (vii) Settled Land and Trustee Acts (Court's General Powers) Act 1943; (viii) Hill Farming Improvements (Settled Land Act and Trusts for Sale) Regulation SI 1951/1816; (ix) Law of Property Act 1922, s 43; (x) Limited Owners Residences Act 1870; (xi) Limited Owners Residences Act (1870) Amendment Act 1870; (xii) Improvement of Land Act 1864; (xiii) Improvement of Land Act 1899; (xiv) Law of Property (Entailed Interests) Act 1932; (xv) District Councils (Water Supply) Facilities Act 1897; (xvi) Law of Property Amendment Act 1926; (xvii) Fines and Recoveries Act 1833.

\section{Administration of Estates Act 1925}

(a) The Administration of Estates Act 1925, section 51(2) is repealed. ${ }^{357}$

\section{Waste \& Distress}

(a) The Statute of Marlborough (Marlbridge) 1267 is repealed.

\section{6. $\underline{\text { Repeals }}$}

(a) The following are repealed: (i) Literary and Scientific Institutes Act 1854; (ii) School Sites Acts 1841; (iii) School Sites Act 1844; (iv) School Sites 1849; (v) School Sites Act 1851; (vi) School Sites Act 1852;

(b) The following are repealed: (i) Conveyancing Act 1881; (ii) Land Settlement (Facilities) Act 1919; (iii) Law of Property Act 1922; (iv) Law of Property (Amendment) Act 1924; (v) Land (Authorisation Procedure) Act 1946.

\section{APPENDIX B - REMAINING LAND LEGISLATION 1267-2017}

(a) Landlord \& Tenant Acts

- $\quad$ Crown Lands Act 1623, ss 1 \& 2

- $\quad$ Crown Lands Act 1702, ss 5 \& 7

- $\quad$ Landlord and Tenant Act 1709, s 4

- $\quad$ Landlord and Tenant Act 1730, s 1

- $\quad$ Crown Lands Act 1833, s 8 (spent)

- Crown Lands Act 1851, ss 15, 21, $23^{358}$

- $\quad$ Common Law Procedure Act 1852, ss 210-2, 214, 218

- $\quad$ Apportionment Act 1870, ss 2-7

- Law of Property Act 1922, s 145

- $\quad$ Law of Property Act 1925, ss 139-54 (leases \& tenancies)

- $\quad$ Landlord and Tenant Act 1927

- $\quad$ Leasehold Property (Repairs) Act 1938

\footnotetext{
${ }^{354}$ It may be noted that, if the Norman system of tenures was abolished (as discussed in the second article), neither this provision nor the Statute of Quia Emptores 1290 would be needed.

${ }^{355}$ The Crown was not bound by Quia Emptores 1290. Nor did it apply to estates in fee tail or life interests. However, (a) extends to the same. ${ }^{356}$ See $\mathrm{n} 277$ (Bolton, Marlborough and Wellington estates).

357 This means that the estate of a women of unsound mind pre-1926 who dies intestate shall not descend by way of the curtesy of England. It shall be governed by the intestacy rules laid down in the Administration of Estates Act 1925. So too, that of any other 'defective' ('idiot') where the AEA 1926, s 51(2) applies.

${ }^{358}$ Section 22 (relating to parks) should be inserted in an OSA (see 7).
} 
- $\quad$ Landlord and Tenant (War Damage) Act 1939

- $\quad$ Landlord and Tenant (War Damage) Amendment Act 1941

- $\quad$ Landlord and Tenant (Requisitioned Land) Act 1942

- $\quad$ Landlord and Tenant (Requisitioned Land) Act 1944

- $\quad$ Requisitioned Land and War Works Act 1945

- $\quad$ Requisitioned Land and War Works Act 1948

- $\quad$ Landlord and Tenant Act 1954

- Costs of Leases 1958

- $\quad$ Law of Property (Joint Tenants) Act 1964

- $\quad$ Leasehold Reform Act 1967

- Law of Property Act 1969, ss 1-15 (amends Landlord and Tenant Act 1952)

- $\quad$ Rent (Agriculture) Amendment Act 1977 (spent)

- $\quad$ Rentcharges Act 1977

- $\quad$ Rent Act 1977

- $\quad$ Leasehold Reform Act 1979

- $\quad$ Landlord and Tenant Act 1985

- $\quad$ Rent (Amendment) Act 1985

- $\quad$ Landlord and Tenant Act 1987

- $\quad$ Reverter of Sites Act 1987

- $\quad$ Landlord and Tenant Act 1988

- $\quad$ Landlord and Tenant (Licensed Premises) Act 1990

- $\quad$ Agricultural Tenancies Act 1995

- $\quad$ Landlord and Tenant (Covenants) Act 1995

- $\quad$ This should be inserted in a new Landlord and Tenant Act. A Housing Act could then consolidate the Housing Acts 1980, 1985 and 1988 as well as the: Protection from Eviction Act 1977, Leasehold Reform Act 1979, Local Government (Miscellaneous Provisions) Act 1982 (ss 33, 49), Housing Associations Act 1985, Housing (Consequential Provisions) Act 1985, Local Government Act 1988 (ss 24-6, 40, 42), Housing and Urban Development Act 1993 and Commonhold and Leasehold Reform Act 2002.

(b) Acquisition of Land

- $\quad$ Lands Clauses Consolidation Act 1845

- $\quad$ Lands Clauses Consolidation Acts Amendment Act 1860, ss 1-2,4-5, 7-8

- $\quad$ Acquisition of Land (Authorisation of Procedure) Act 1946

- $\quad$ Land Compensation Act 1961

- $\quad$ Land Compensation Act 1973

- $\quad$ Acquisition of Land Act 1981

This should be inserted in a new Land Act.

\section{(c) Land Registration \& Charges}

- $\quad$ Land Registration Act 1936 (spent)

- $\quad$ Land Charges Act 1972

- $\quad$ Land Registration Act 1986

- $\quad$ Land Registration Act 1997

- $\quad$ Land Registration Act 2002

This should be inserted in a new Land Act. 
(d) Land Drainage

- $\quad$ Land Drainage Act 1976

- $\quad$ Land Drainage Act 1991

- $\quad$ Land Drainage Act 1994

(e) General

- $\quad$ Cestui que Vie 1666, ss 1 \& 4

- $\quad$ Cestui que Vie Act 1707, ss 2-5

- Law of Property Act 1925

- $\quad$ Prescription Act 1832, ss 1-9

- $\quad$ Sale of Land by Auction Act 1867, ss 3-9

- $\quad$ Lands Tribunal Act 1949

- Law of Property Act 1969, ss 17-9, 21-5, 28 (for other ss, see above)

This should be inserted in a new Land Act.

\section{(f) Crown Land}

- $\quad$ Crown Land Act 1819

- Crown Lands Act 1823(spent)

- Crown Lands Act 1851, ss 1-2

- Crown Private Estate Act 1800

- Commissioners of Works Act 1851

- Crown Private Estates Act1862

- Crown Private Estates Act 1873

- Customs Building Act 1879, ss 2, 3, 5359

- Inland Revenue Buildings Act 1881, ss 2-6 360

- Crown Lands Act 1894

- Crown Lands Act 1906, ss 3, 6, $10^{361}$

- Crown Lands Act 1927

- $\quad$ Crown Lands Act 1936, ss 1-9

This should be inserted in a new Crown Act, which could also include legislation on the Crown Estate.

\section{APPENDIX C - LAND ACT 20 山}

A consolidation Act called the Land Act should consolidate all land legislation - assuming the legislation referred to in Appendix A is repealed. The basis would be the extant sections in the Law of Property Act 1925, save for sections dealing with:

- leases and tenancies - pt 5, these should be in a Landlord and Tenant Act;

- mortgages

- formalities - pt 3, these should, one day, be in a distinct Mortgage Act;

- wills - pt 2, in part, these should, one day, be in a Formalities Act; - pt 10, these should be in a Wills Act.

Thus, the new Land Act would have the following parts:

Part 1 - Forms of Landholding

\footnotetext{
${ }^{359}$ These sections should be inserted into the Commissioners of Works Act 1852. Some of the material is spent.

${ }^{360}$ Ibid.

${ }^{361}$ Section 7 of this Act relates to Kew and should be inserted in an Open Spaces Act (see 7).
} 
Part 2 - Registration of Land \& Land Charges ${ }^{362}$

Part 3 - Sale of Land ${ }^{363}$

Part 4 - Prescription 364

Part 5 - Compulsory Acquisition of Land 365

Part 6 - Other Acquisition of Land

Part 7 - General

\section{APPENDIX D - EXAMPLE OF PRIVATE INCLOSURE ACT}

An example of a private inclosure Act (and the standardised form of contents) is An Act of 1779 for 'Dividing and Inclosing the Common Fields, Common Meadows, Common Pastures, Commonable Lands, and Waste Grounds, within the Manor and Parish of Buckland, in the County of Gloucester.' It comprises the following:

1. Preamble. 'Whereas there are within the manor and parish of Buckland...several open common fields, common meadows, common pastures, commonable lands, and waste grounds, containing, by estimation, [2000] acres, or thereabouts...

whereas...Lord Weymouth ['Weymouth'] is lord of the said manor, and owner of all the lands and grounds within the said parish (except the glebe lands) and is also patron of the rectory of the parish and parish church of Buckland...and is seised of and entitled to the perpetual advowson and right of patronage and presentation of, in, and to the said rectory and parish church, and entitled to a moiety or half part of the tythes of corn and grain, arising and increasing from and out of all such lands within the said parish as are tytheable:

and the Rev...Vanburgh is the present rector of the said rectory and parish church, and as such is entitled to certain glebe land within the said parish, and to the other moiety or half part of the tithes of corn and grain payable within the said parish, and is also entitled to the tithes of hay, and other great tithes, arising from and out of the titheable lands within the said parish, and to the customary payment or yearly sum of [2s $6 \mathrm{~d}]$ in respect of the tithe of a certain plot or parcel of ground, within the said parish...called [ ]; and also to all the small tithes payable within the said parish:

and whereas several other persons are, by virtue of leases for lives, or years determinable upon lives, heretofore granted, entitled to certain parts of the said open common fields and common meadows, which are divided into, and together with the homesteads thereof, are known by the name or denomination of livings, and parts of livings; and the said rector, and the said leaseholders aforesaid, are entitled to right of common upon the said open common fields, common meadows, common pastures, commonable lands, and waste grounds:

and whereas the several lands within the said open common fields and common meadows lie intermixed, and dispersed in small parcels, and the same, and also the said common pastures, commonable lands, and waste grounds, are frequently in part overflown, and in their present situation are incapable of any considerable improvement; and it would be very advantageous to the several owners and proprietors thereof, and persons interested therein, if the same were divided, inclosed, and specifically allotted and awarded, in manner hereinafter mentioned; but the same cannot be so done without the aid and authority of Parliament...

2. Commissioners, Survey \& Roads. Sections dealt with:

- the appointment of certain commissioners;

- their oath;

- their giving notice of meetings;

- survey of the fields;

- making public and private roads, viz. the commissioners:

\footnotetext{
362 The legislative material would be that in Appendix B(c).

${ }^{363}$ The legislative material would be that in the Sale of Land by Auction Act 1867 (as modernised).

${ }^{364}$ The legislative material would be that in the Prescription Act 1832 (as modernised).

365 The legislative material would be that in Appendix B(b). See also Ubhi, n 11, ch 12.
} 
are hereby authorised and required to cause such public and private roads and ways to be made and set out, in, over, and upon the lands and grounds hereby intended to be divided and inclosed.....and also such ditches, bridges, causeways, banks, sluices, drains, watercourses, and other requisites for draining and improving the said lands and grounds, as the ...commissioners...shall think proper and necessary;

all of which public roads shall be and remain [40 feet] broad at least between the ditches (except bridle roads and foot ways, in case and such shall be set out); and all such public roads shall be made, and at all times for ever thereafter repaired and kept in repair, in such manner as the other public highways within the said parish are repaired and kept in repair;

and that after the making the roads and ways so to be set out and appointed as aforesaid, it shall not be lawful for any person or persons to use any roads or ways, either public or private, over the lands and grounds to be divided and allotted in pursuance of this Act, either on foot or with horses, cattle or carriages, other than such new roads or ways as shall be set out and appointed as aforesaid, and usage or custom to the contrary hereof notwithstanding;

and all former roads and ways, which shall not be set out and appointed as the roads and ways through the said allotments, shall be deemed as part of the lands and grounds to be divided by virtue of this Act, and shall be set out an allotted accordingly; and the grass and herbage growing and renewing in and upon the said roads and ways to be set out as aforesaid, shall be allotted to such of the said proprietors of the lands and grounds hereby intended to be divided and inclosed, as the...commissioners...shall think proper.

3. Allotments \& Fencing. Sections dealt with:

- allotment for stone quarries; ${ }^{366}$

- allotment to Weymouth for his moiety (portion) of the tithes of corn and grain;

- allotment to the rector for glebe. Also, his moiety of the tithes (and dues and payments in lieu);

- rentcharges payable to Weymouth and the rector for the tithes of such inclosures, for which compensation in land could not be made;

- allotment of residue; ${ }^{367}$

- commissioners to have regard to the quality of the lands subject to allotment;

- commissioners to determine differences;

- commissioners not to determine on any matter of title;

- allotments to be in bar of former rights;

- fencing the allotments to the rector and other proprietors;

- satisfaction to be made to such proprietors as shall have too great a share of fencing;

- fencing allotments of such proprietors as shall neglect to fence;

- fences could be made before execution of the award;

- gaps to be left;

- preserving fences.

4. General. Sections dealt with:

- no sheep or lambs to be kept in the new inclosure for a certain time; ${ }^{368}$

\footnotetext{
366 'the...commissioners shall also set out and allot to and for...Weymouth, as lord of the manor of Buckland....such parcel or parcels of the lands and grounds by this Act intended to be divided and inclosed, not exceeding [2 acres] for public pits or quarries, for furnishing materials for the repair of the roads and highways within the parish of Buckland...and for erecting, repairing, and supporting such buildings and walls as shall be made on or in respect of any of the allotments which shall be made in pursuance of this Act, and for repairing and supporting such as are now standing or being in the said parish, and erecting and supporting such as may hereafter be built there; which said parcel or parcels of ground so to be set out and allotted, shall from thenceforth be vested in the lord [of Buckland manor], for ever, in trust for the inhabitantsof the parish of Buckland...for the uses and purposes aforesaid, and for no other use or purpose whatsoever; and the same shall be free from all taxes whatsoever.'

367 'after the several allotments hereinbefore mentioned shall be made and set out, the ...commissioners...shall, and they are hereby required to apportion, divide, set out, and allot the residue and remainder of the said open common fields, common meadows, common pastures, commonable lands, and waste grounds, unto and for ...Weymouth, and the several other owners, proprietors, and lessees thereof, and persons interested therein, according to their respective rights, shares, and interests therein.'
} 
- trees and underwoods to belong to former proprietors;

- hedges to remain;

- Weymouth to provide timber for buildings in case of a deficiency on the allotments;

- lands may be exchanged;

- commissioners may direct the course of husbandry;

- commissioners to make an award;

- allotments to be accepted within a certain time. ${ }^{369}$

6. Guardians, Wills. Sections dealt with:

- guardians could accept for incapacitated persons;

- non acceptance of guardians etc not to prejudice infants;

- wills, settlements etc not to be affected.

7. Leases, Mortgages. Sections dealt with:

- vacating leases at rack rent;

- impowering the rector to grant leases;

- expenses of the Act to be paid by all the parties to whom allotments shall be made, except the rector;

- proprietors advancing money to be repaid with interest;

- power to borrow money;

- Weymouth empowered to borrow money to erect a farm house and other conveniences;

- rector may borrow money;

- commissioners to direct the application of the money to be borrowed;

- mortgages to be valid.

8. Commissioners \& Savings. Sections dealt with:

- commissioners to account;

- electing new commissioners;

- allowing an appeal on any award matter to the quarter sessions;

- saving the rights of the lord of the manor;

- saving to the Crown.

Notes. In both local and private inclosure Acts, the crucial thing was not so much the Acts (which empowered inclosure) but the award (as amended by any appeal). Also, often, parties exchanged land (as they were entitled to do, see 4 above) after an award, to secure a better outcome, commercially or agriculturally. Thus, the factual outcome, in practice, was, often, different from the terms of the Act.

\section{Copyright}

Copyright for this article is retained by the author(s), with first publication rights granted to the journal.

This is an open-access article distributed under the terms and conditions of the Creative Commons Attribution license (http://creativecommons.org/licenses/by/4.0/).

\footnotetext{
${ }^{368}$ The time specified was 7 years, to 'guard and protect the young quickset fences round such allotments from being hurt or damaged by such sheep or lambs'.

369 'the several persons to whom allotments shall be made in pursuance of this Act, shall accept their respective allotments and shares, by taking possession thereof, within [6 months] next after the execution of the said award or instrument being publicly read [in Buckland parish church] and in each case any person shall refuse or neglect to accept his or her share or allotment within the [6 months] such person shall nevertheless be totally excluded from having or receiving any estate, interest, right of common, or other property whatsoever, in or to any of the lands or grounds which shall be assigned or allotted to any other person or persons in pursuance of this Act.'
} 